Li Pao.hsün

10
752

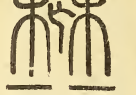

hui yui ehai luas tha shith

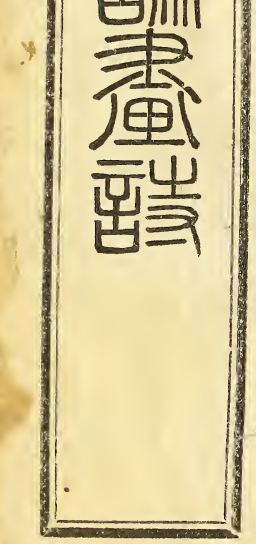




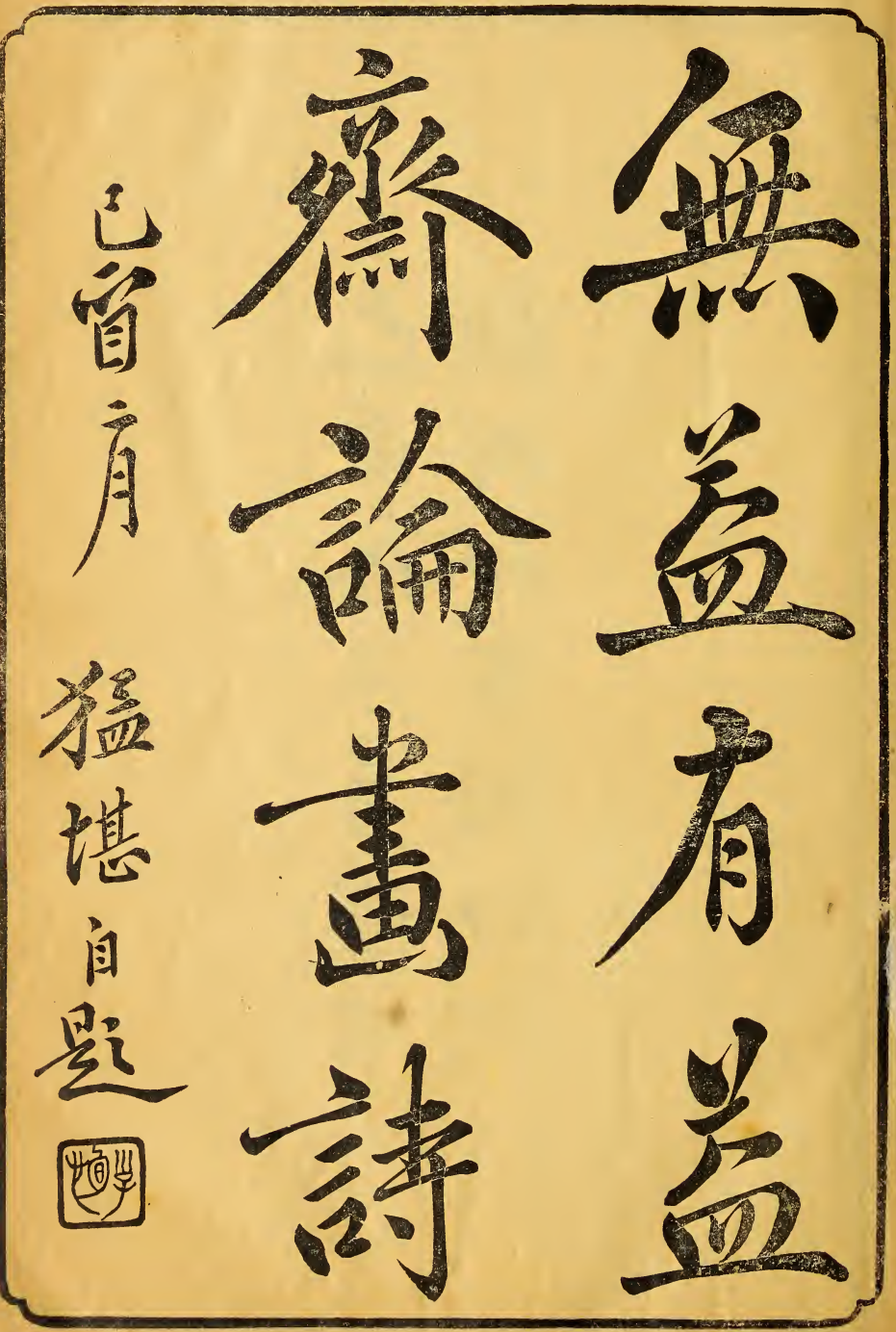




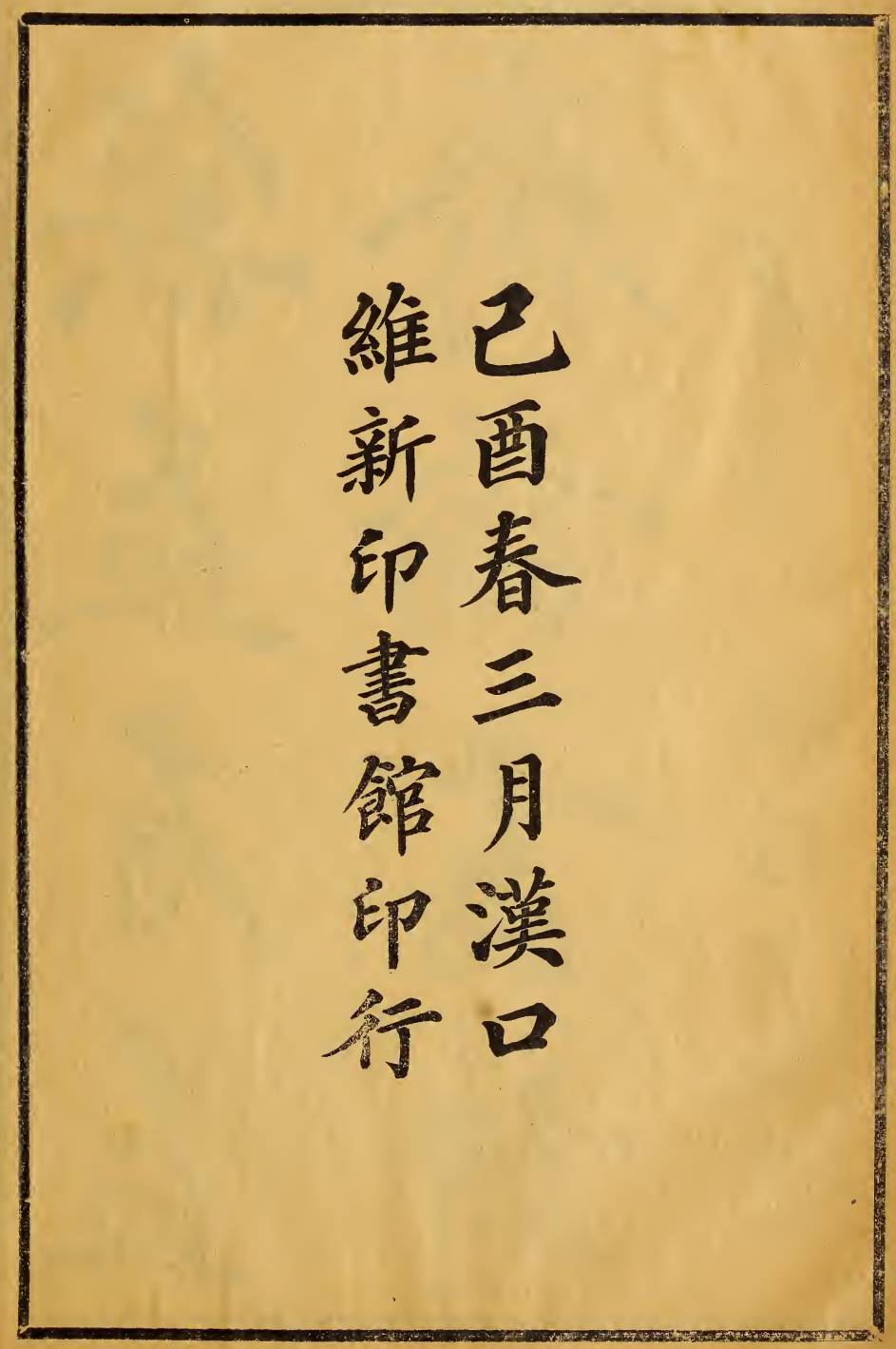


芝入日雞澤蹟方童園不䇾

陔都中黨州乃伯子觀數解

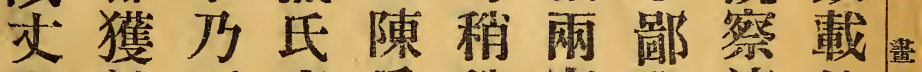

畫見不商氏稍芜我適故

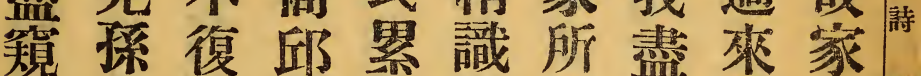

所齐䏩染世苂藏出幕所

藏恪及氏所矣亦所中藏

適会明陳儲光因藏䓒往

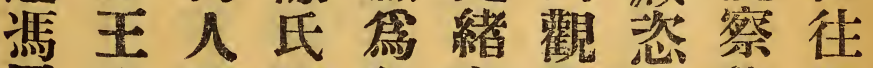

展花軖三佔初察我收於

雲敏日家客重得觀藏圭

永偶之稇䎑徧覽甲擹

及盛啩物載大觀而東小

景意所猫以梁臨郡南市

劍園錄末出值自人叫中

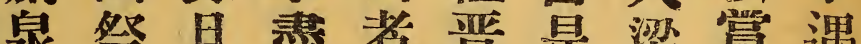

泉祭且荿省是梁貝遇

學酒悔散日预自莎鑑之兄

士張其佚有大磨林名度

故樵劣所所瀻以中於至

物野作見見太來永世雷

零侍矣尤是谷舀楊顧州

市郎已多時孫家当不陸

估李开余珼氏艺焦叫溜 


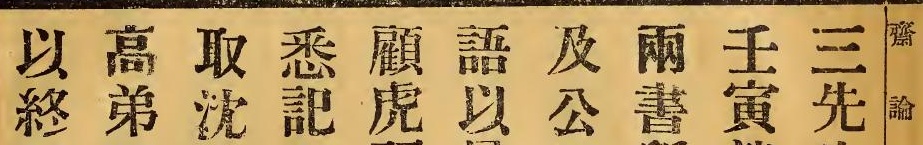

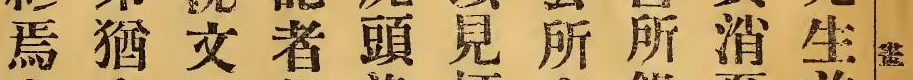

余有唐俱洛梗有䤵复前

素典仇從即概然開訑精

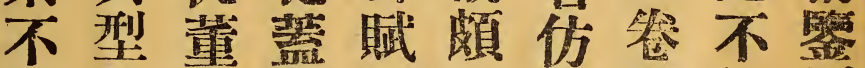

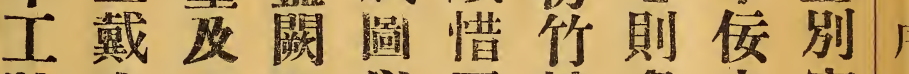

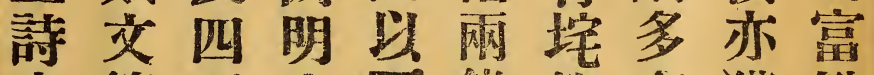

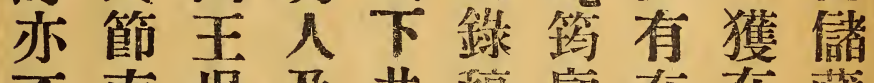

不南哭及共稿廊在在藏

敢宗惲國得概諭者校方

数後之朝自己丵於倁共

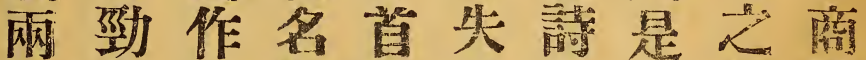

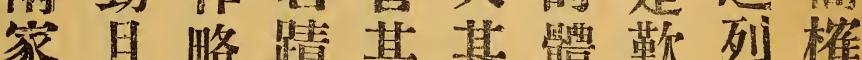

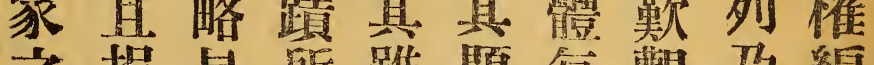

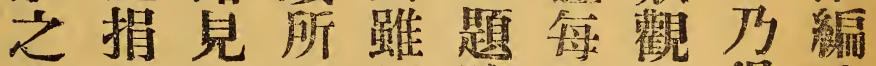

佾軀一見經咙豪止得公

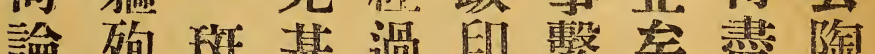

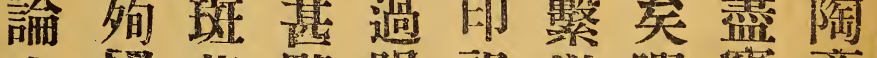

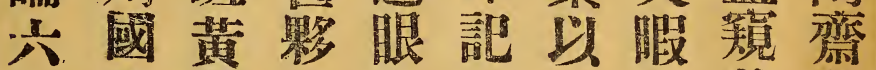

法畫尊不而不二昆羔所 姑苑吉能年能絕憶篟藏

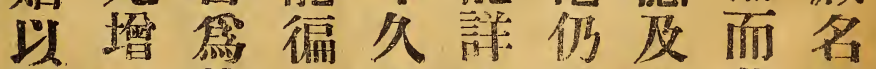

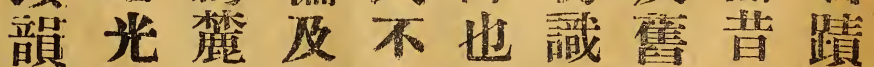
围因台姑能自數物年雼 


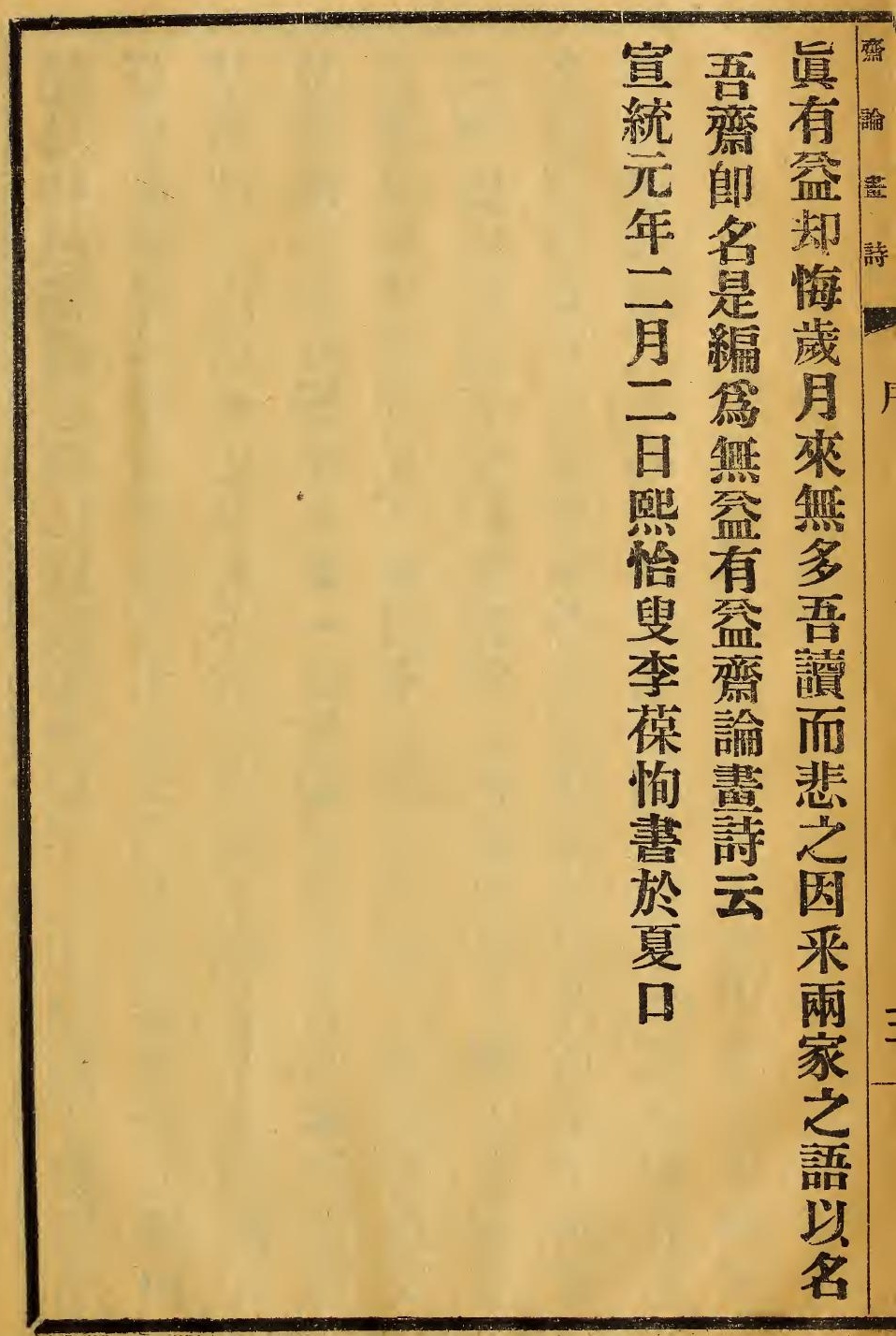




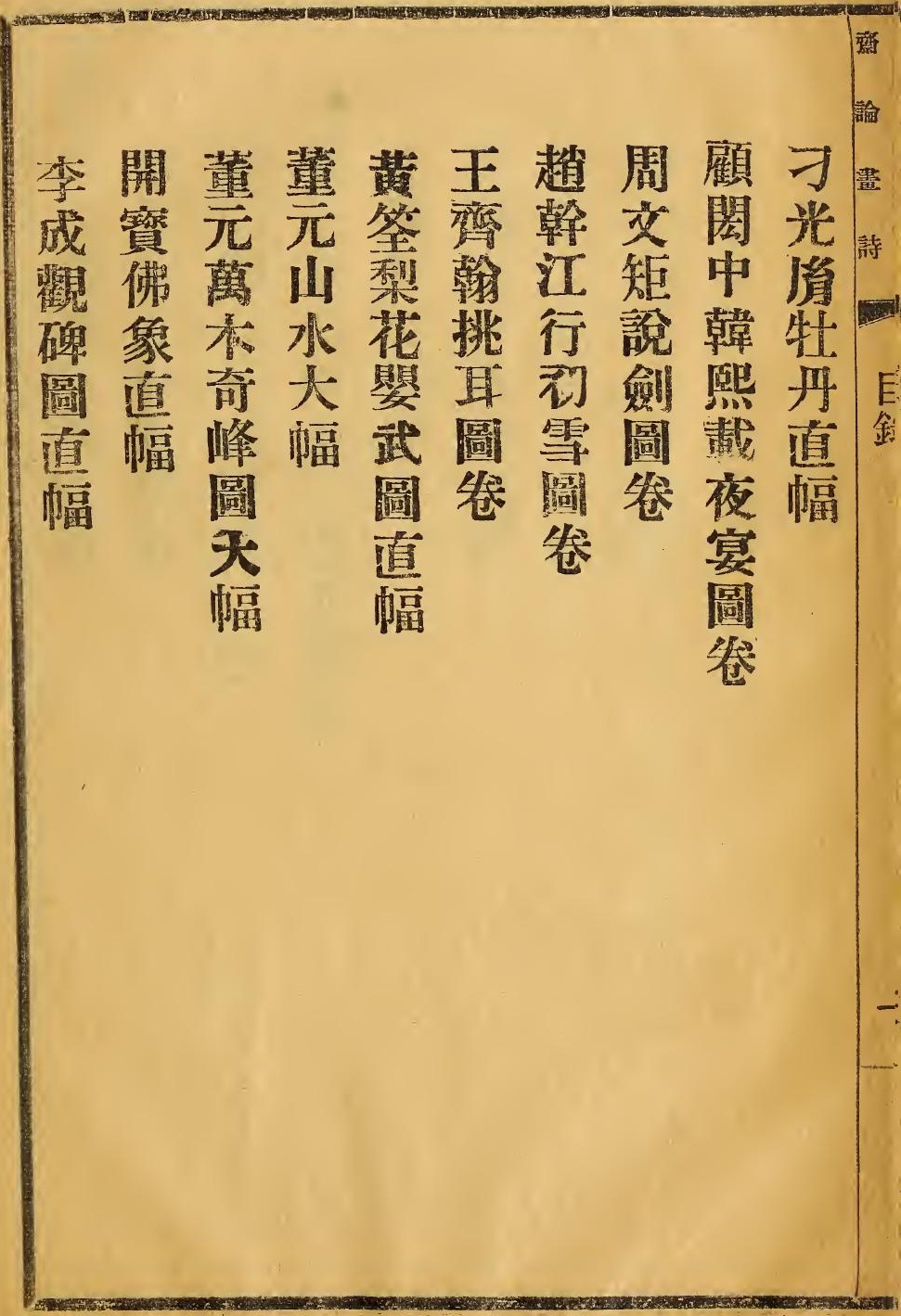




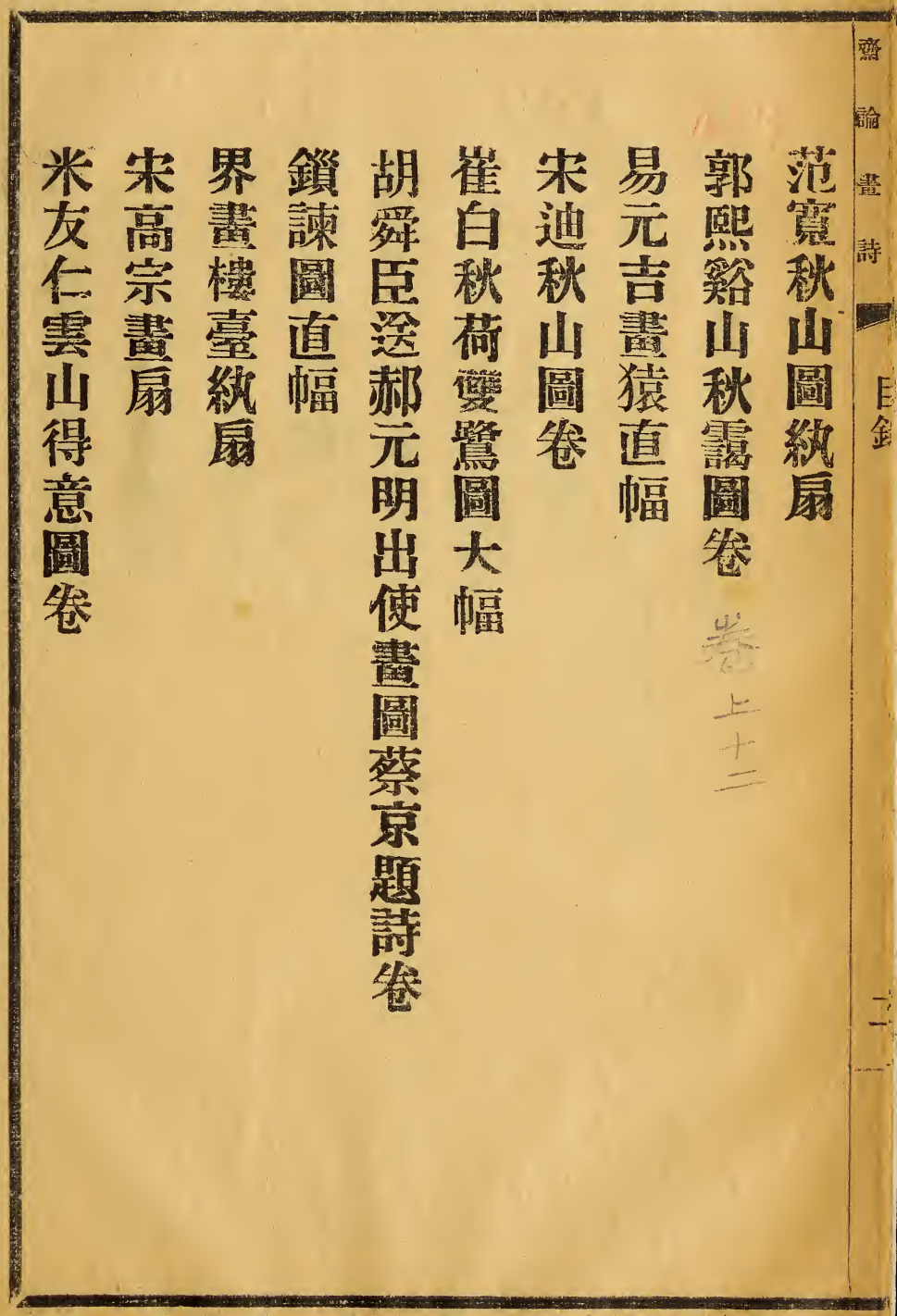




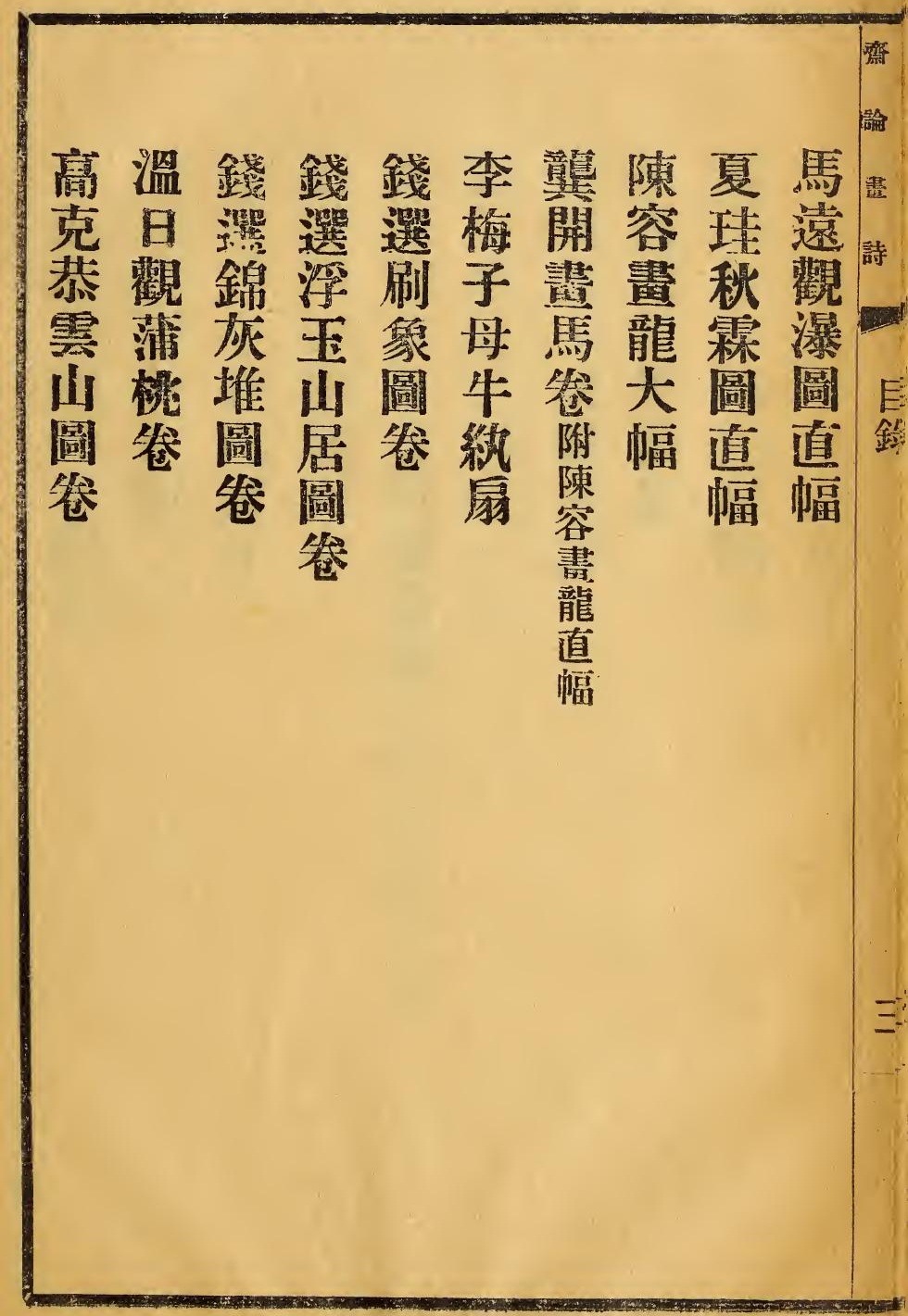




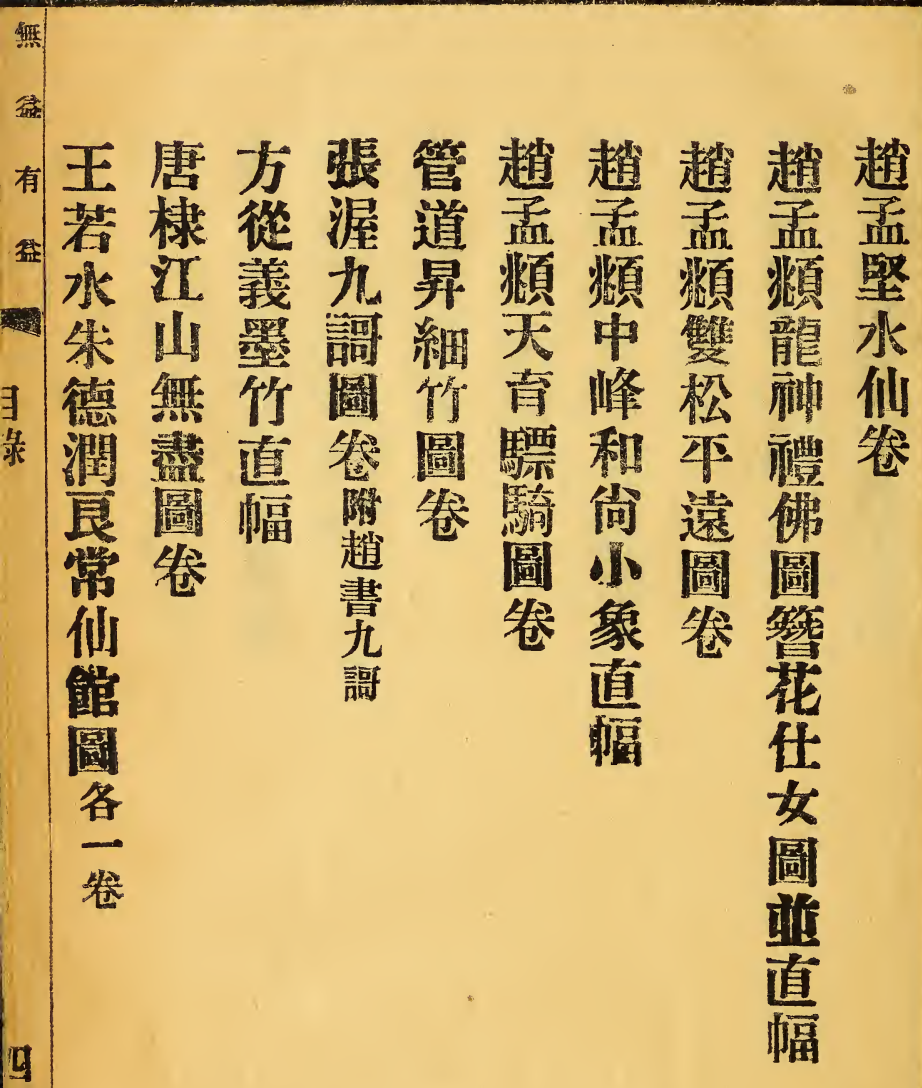




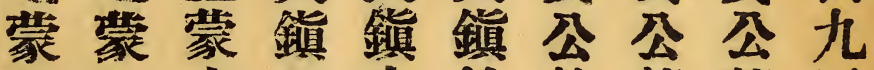
稚山山松山竹㱛骍思 川水水泉水㬐川陵秋竹 移直册圖直舆水餐川䍀 属幅淔幅雨密每册

圖

直



师茼
幅

橫

裝
向

霍

林 彗

圖 圖

铁 


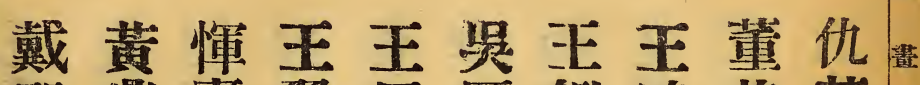
熙鼎壽靟原柲鑑渡其莫

夏長平煙䄮秋大敏昌秋

日江山江臨山龍仿婉堂

山萬水㽬各細淋各變課

居里花嶂家葉圖家草女

圖圖年圖山圖㥕出堂圖

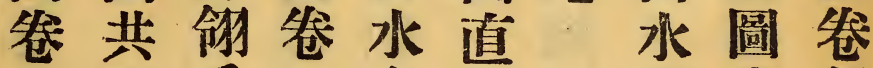

叫毛合幅

卷 册

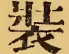

橫

管

册 直 䜪

幅 閵 


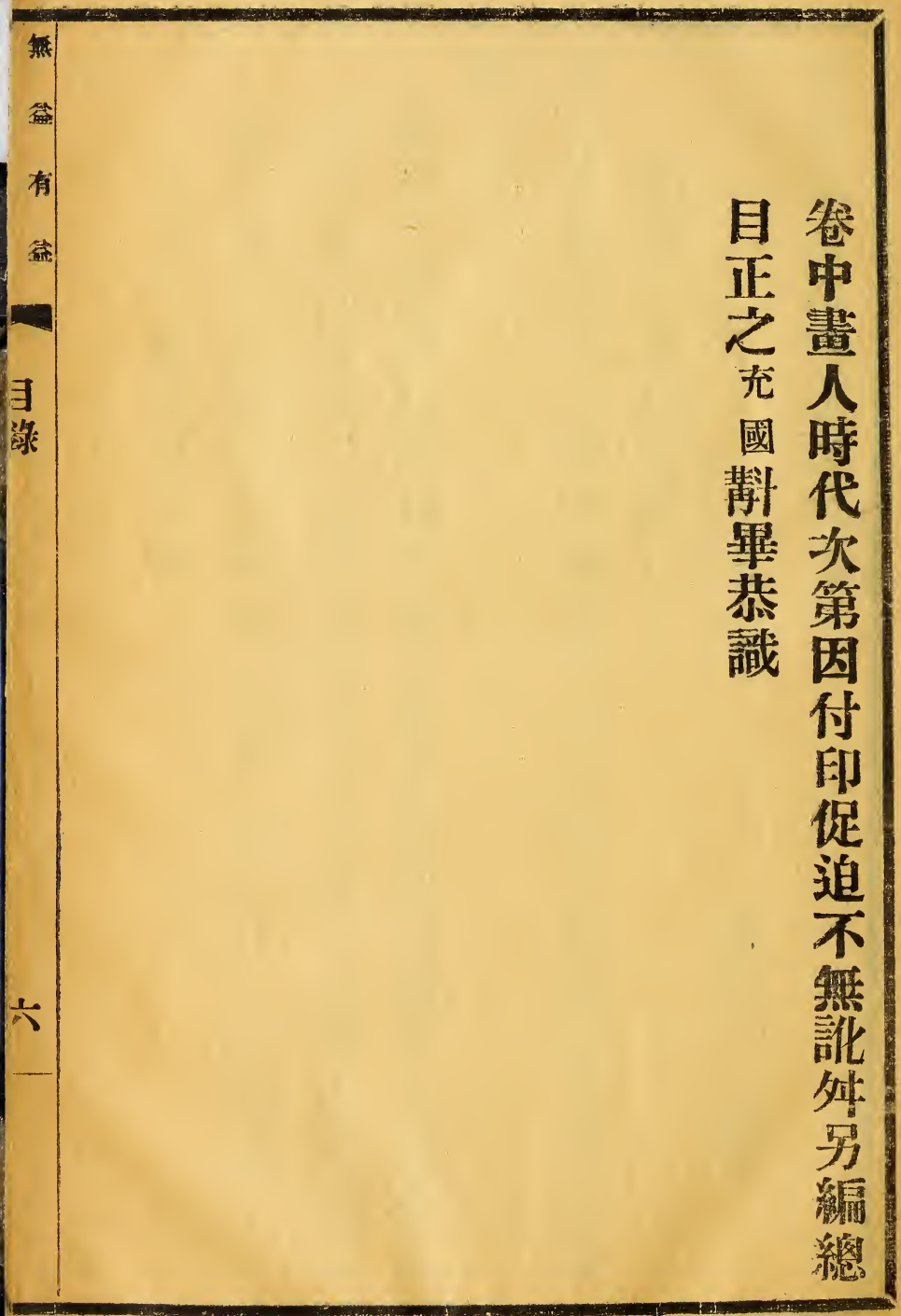





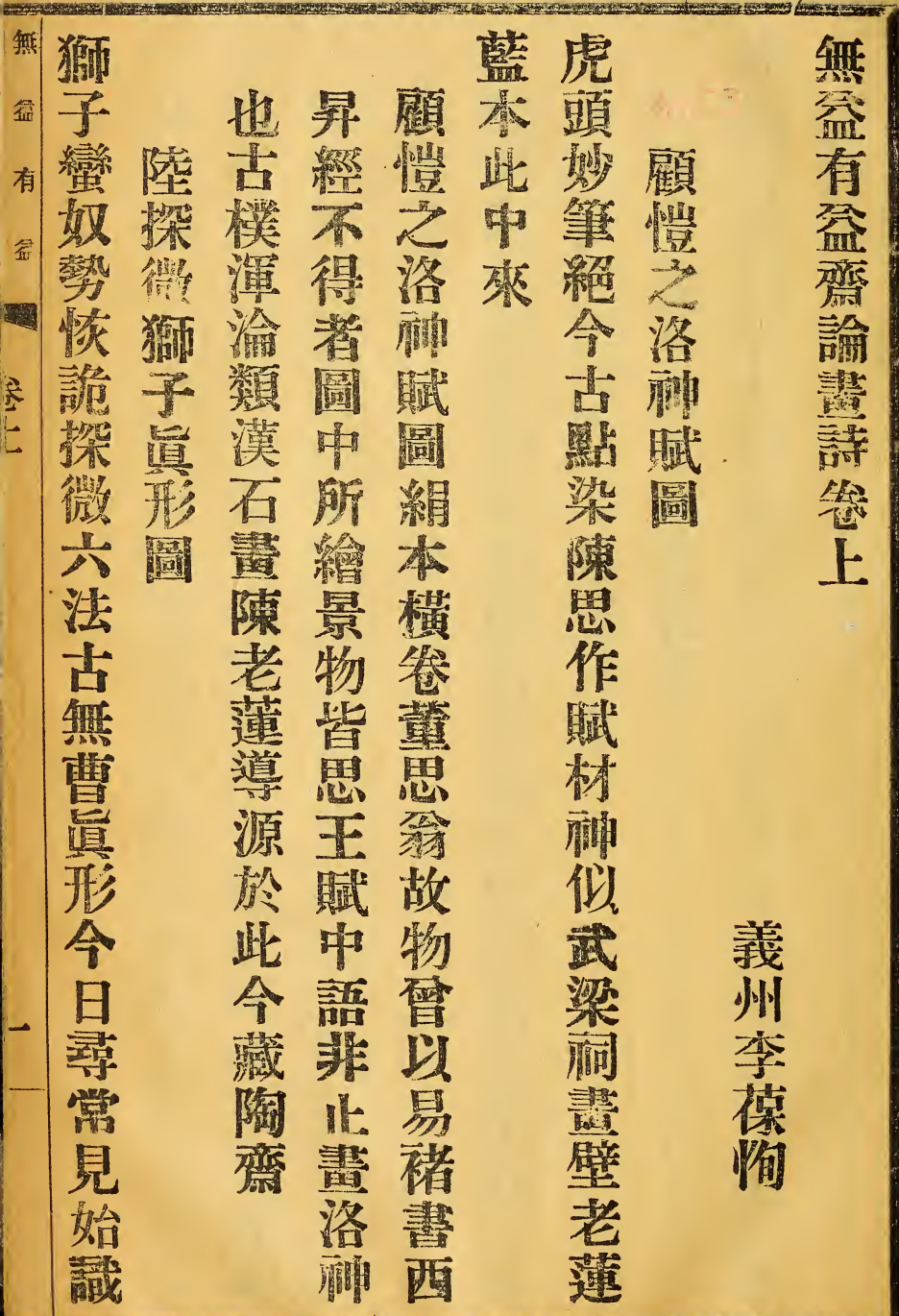


詩 展

㩆 䙐

题

賀屈展蚨们

六然于得笥

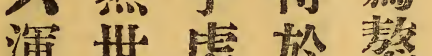

渾世施於謷

佾磁大部

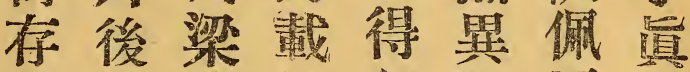

暃

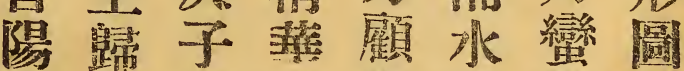

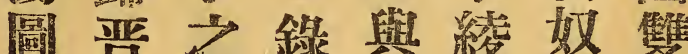

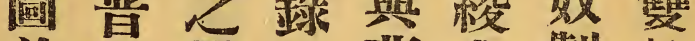

论陽變题曹上製軿

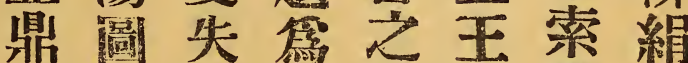

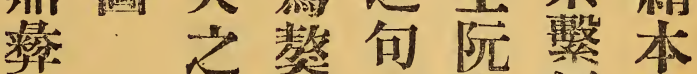

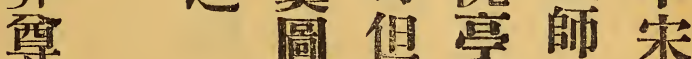

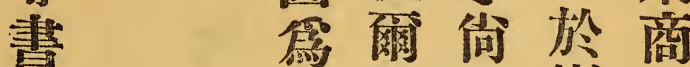

名

試

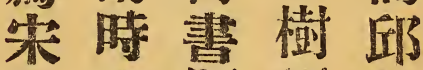

牧末題的故

檢

仰見長形物

郎 㬉謌與 出

川

集

莫

唃子一兮大

賦真直景設

形摹 的色

漫

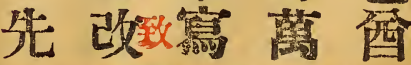

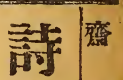

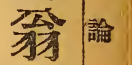

到学

हो

詩

臸

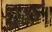

舛

I 


\section{細. 摩}

躍王羊詰

維

1) 星

却 溪

中 霓

過

眼 圖

巽:

Fin

काज

fr?

E 8

나:

政

栭

2.

H望

点急

2)

怒

E

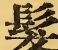

也

邻
非載首尤雖展

王歡就奇可絹子

維矣後染珍素虔

雪 声興地黯督

瀿踏畫光致 後

晋稳緒而主

陽惜丙神齄

圆讙子来 晋

凡後見爛陽

共主於然圖

幅歒絹

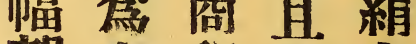

郝高邱車本

艾歡染替橫

忠篇氏旗管

陵失後幟設

川检有之色

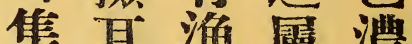

集耳漁屬浱

亦㑕洋可厚

有宣題藉筆

此和七放法

題䛾古古奇

知售一製古 


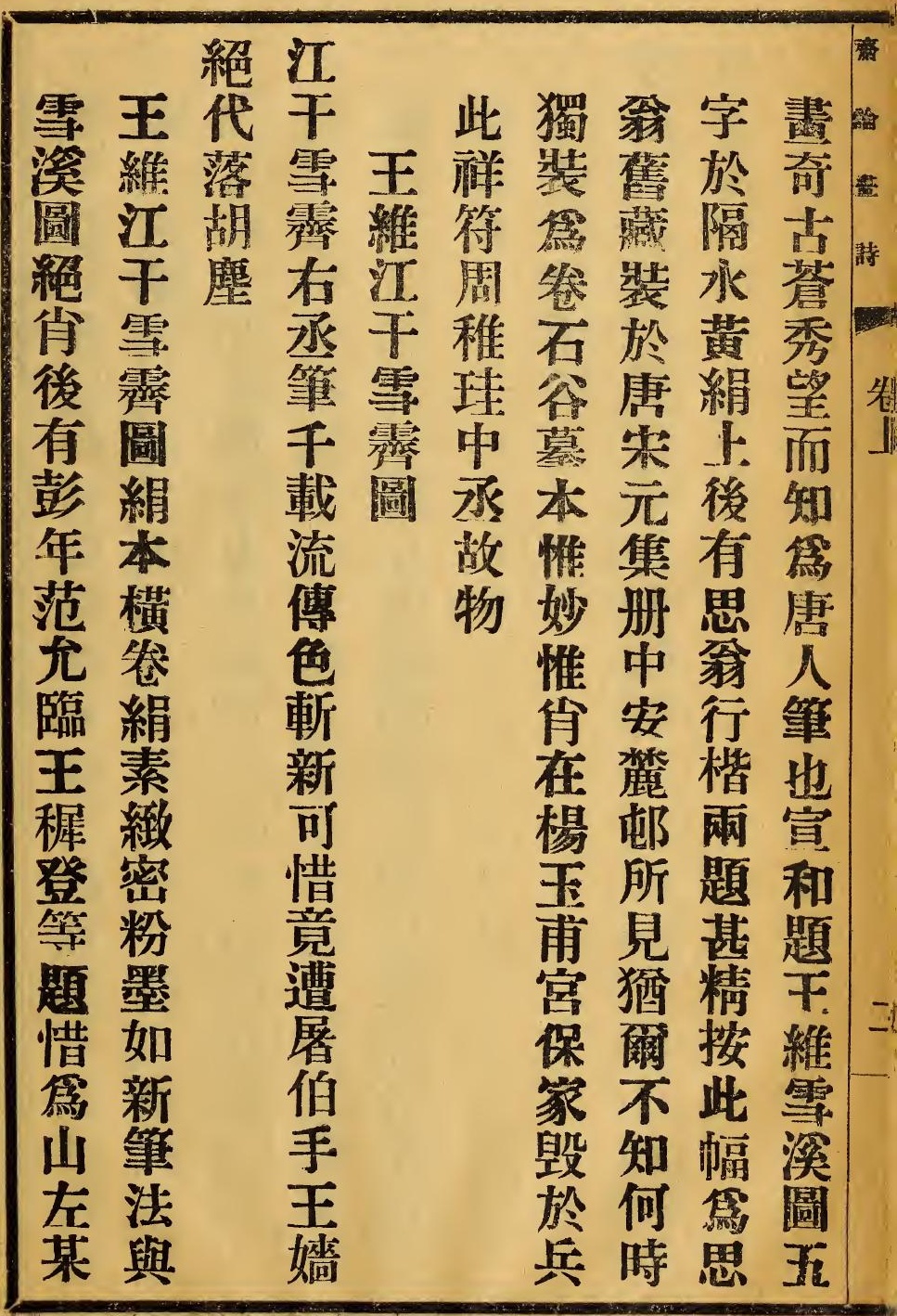




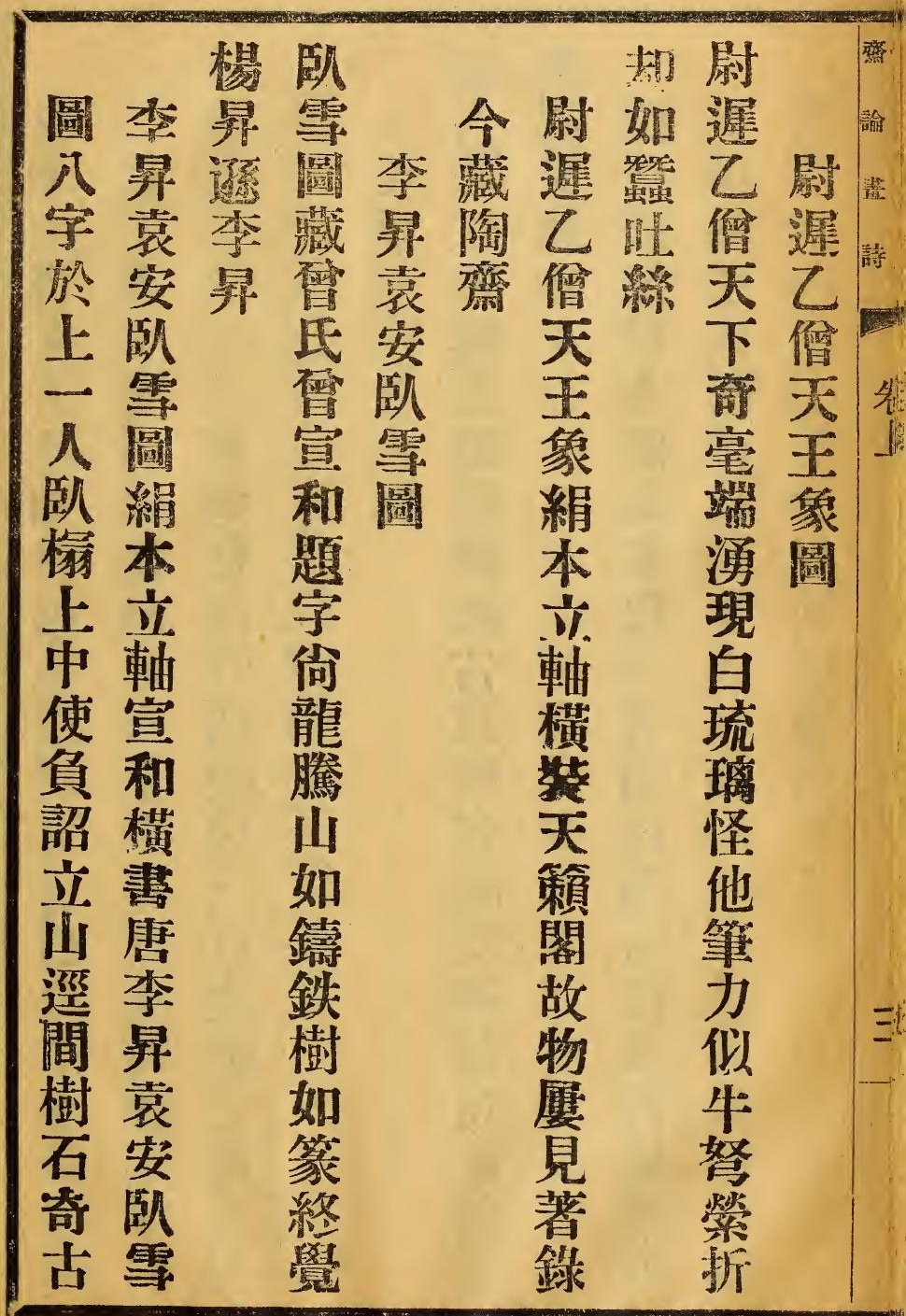




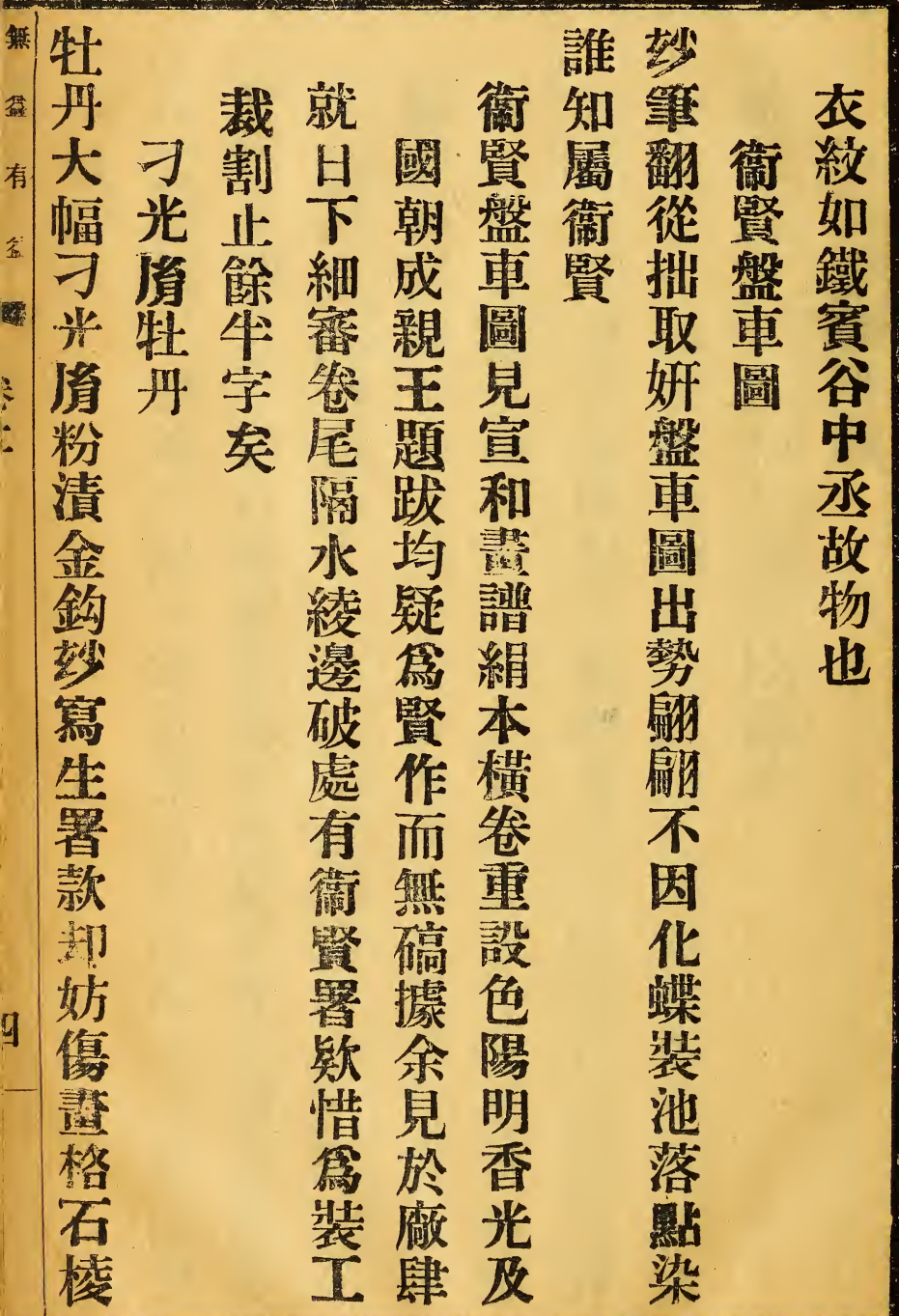


亦待以每輩字署习

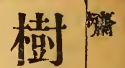

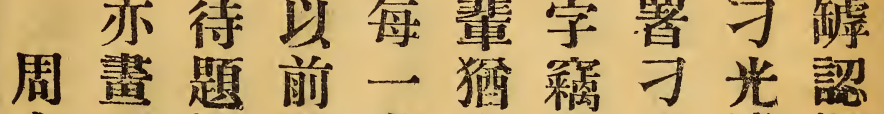

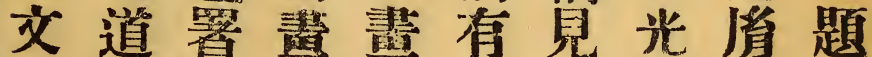
矩开合家成以元㿞牲名 說降則俱題細以三开

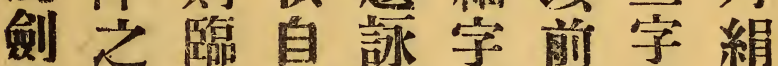
圖原墓成跳書書管本 原基成䨕篦焉随本 也古面幅羟家石大 盛靕目畫臌多絞幅 意往不亦石不横石 園往事因隐䉕斜紋 藏筒陻之處欵曲花 本䢐摹增者盖㧧葉 不正再至现测俱

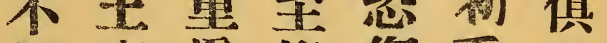
加李遂倪傷看用 知菏至雲畫是全 識關含林棼畫鈎

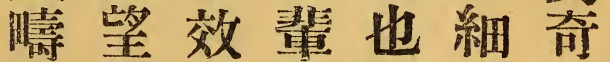

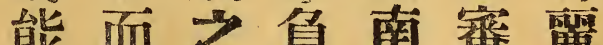
能而之貝南番曧 分可大其株始嚁 别别約詩馬辨目 此何宋書夏是欵 
洉筧

卿㗲王龍翰

顧有尼驾龙

閣割絹翰具

中耳本挑众圆

韓治就且

熙龍绝圖

載棓有亦

夜見東名

宴李坡 勘

圆集子教

今四

今旦

藏王宣

陶晋和

唯 卿 題

齐

度臂

甫翰

榙 妙

題 籍

坡 无

戲等

留 赫
程入

似挑夈宗期

錦耳此題栗

道圖答趙琣

君 秮幹法

題番江奇

字

隻

於

梅

坡

隹

邪

$\underline{\vec{E}}$

ifi.

मิ日

努

天

下

铝

割

院行古

學利淡

生彗着

万回保

代七上

李字粉

氏 作填

晓瘦空

第金處

也體 作

翰笪

南勾

唐 勒
人精幹

王疑 奇 狀

篎 年舍字

入赫 
邱類上架女花顧元恖 董陳令師而樂石䦪羯圖 元氏 若立奏布中鼓中 山 堂之落於景韓 鼔羯欲堂幾熙 而鼓擊下無載 高矣者一隙夜 羯剖鼓人地宴 皷疑圆痋堂圖

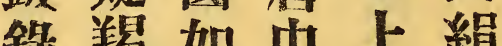

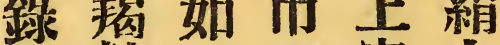
謂鼔㴝裍客本 形師 桶裴數 横 如今徧尔十管 漆樂只面八重 桶部金微各設 観之釷篊有色 此班雙盖醉重 果鼓杖熙容樓 然見似戴若傑 見此椎也聞閣 於始加傍笑雜 确知鼓鼓語以識 


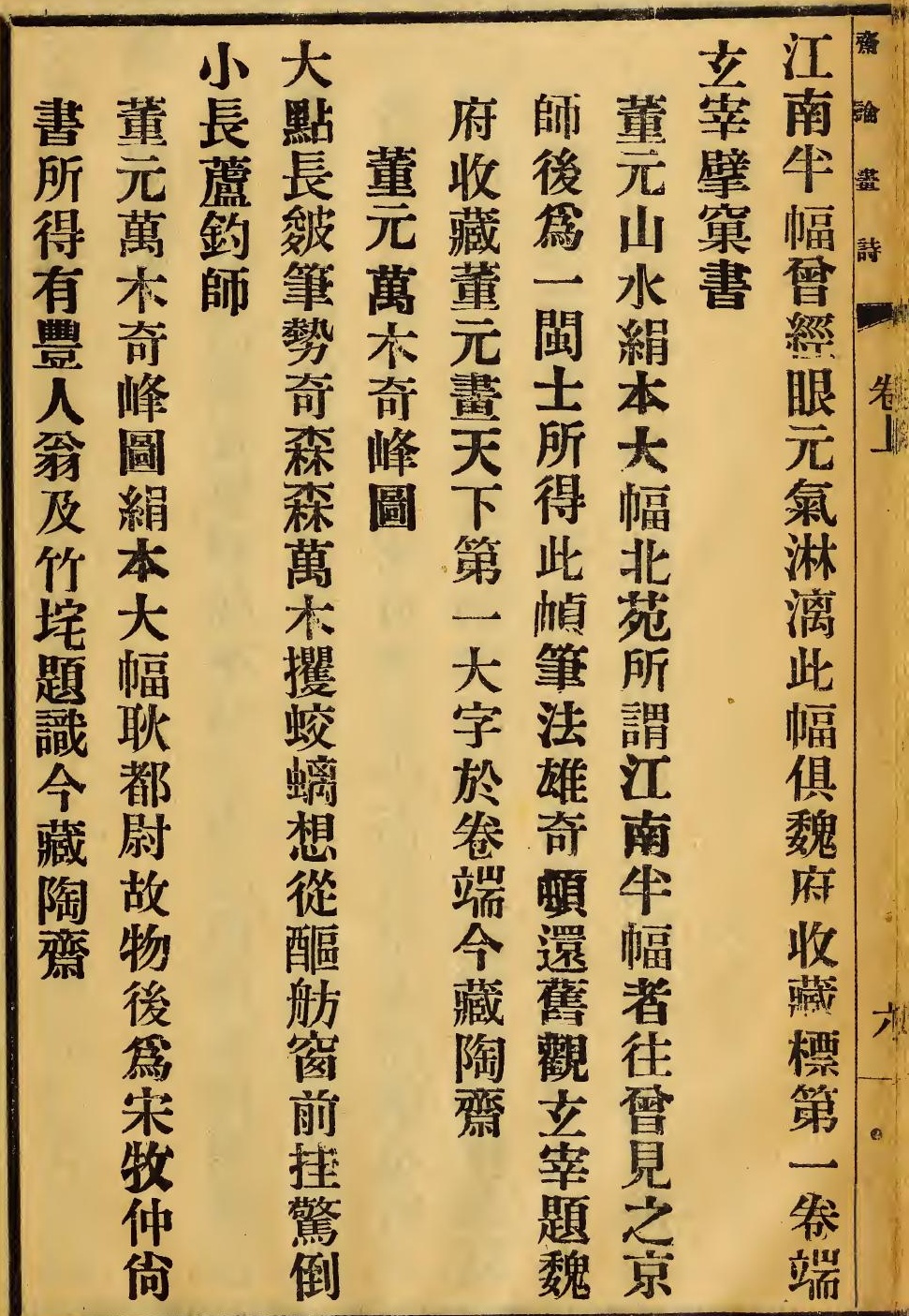




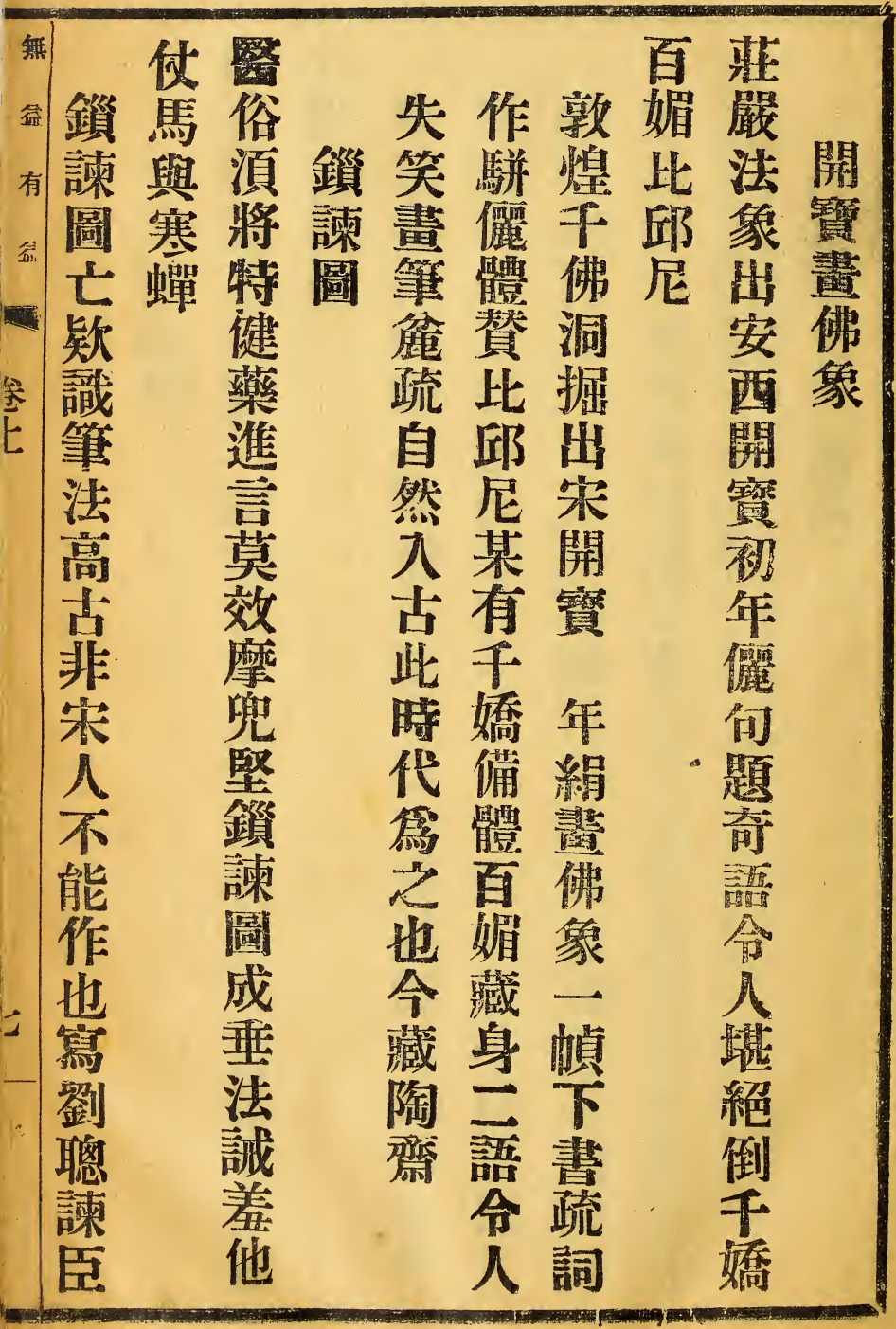




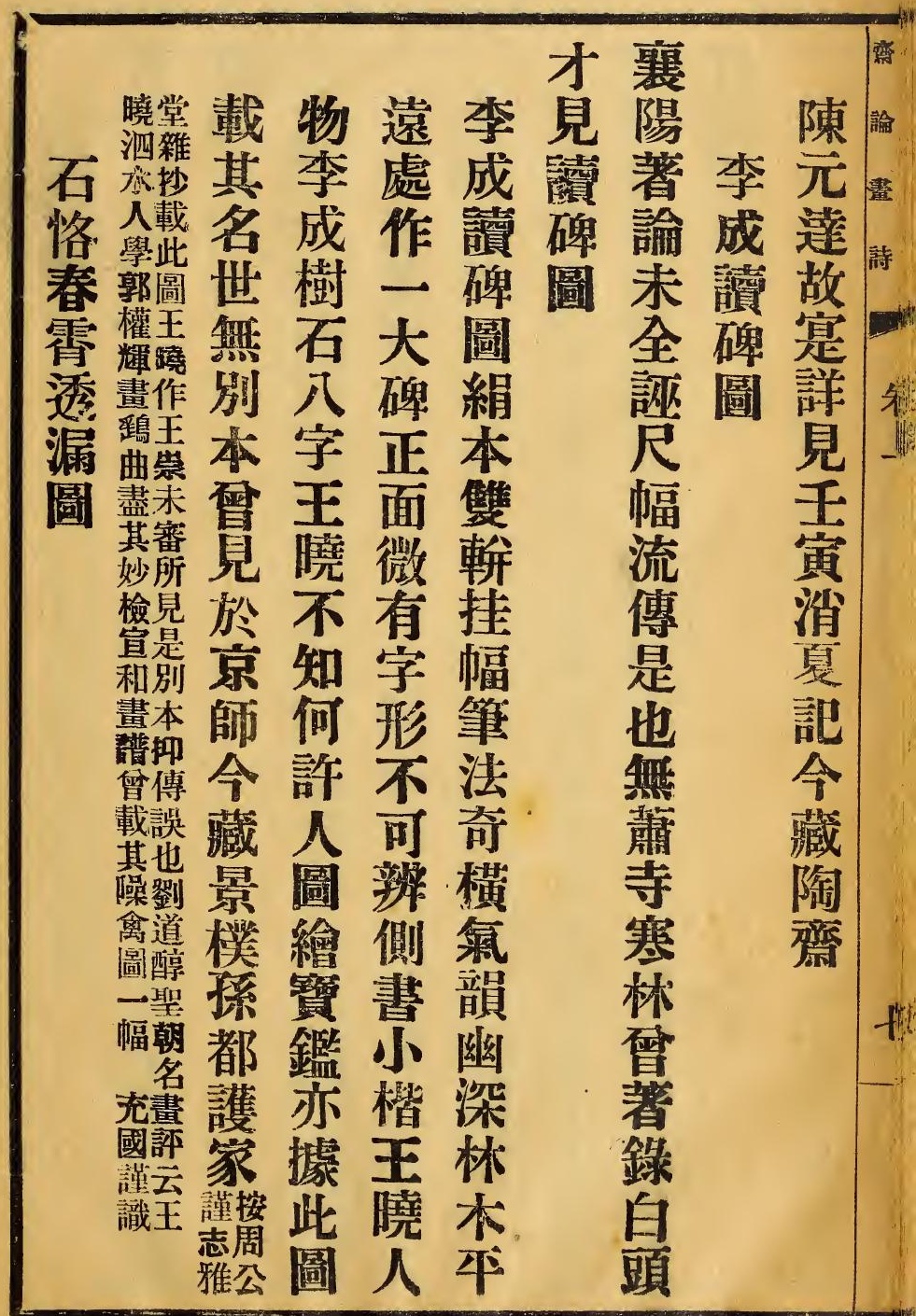


龙 算

鈔在 看

有結紙 燕 衙 本 文 書燕貴 齐山 氏 貴水 水 墨

橿

辜

如

怪

底

眞

山

加

歎

異

銘

心

藏亦物詔石雲想

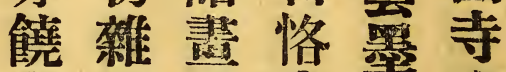

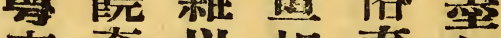
東奇以相春幻 趣鬼國霄圆 中 傳 蕫 壁 梁往壁漏 以昆伴圆 後王狂紙 人孤赀本 所雲酒粬 能墨放䓡 逮勾還恪 也解此字 留低圖子 後圖自專 朱似題蜀 澤原霨人 民本春篓 跋於霄初 甚此涹空 詳樹漏虽 仹樹瘺京 今石人奉
子

專

絕

筆

世

間

40.

犁

霄

唀

漏

5

a

称

本

不

數 


\begin{tabular}{|c|c|c|}
\hline 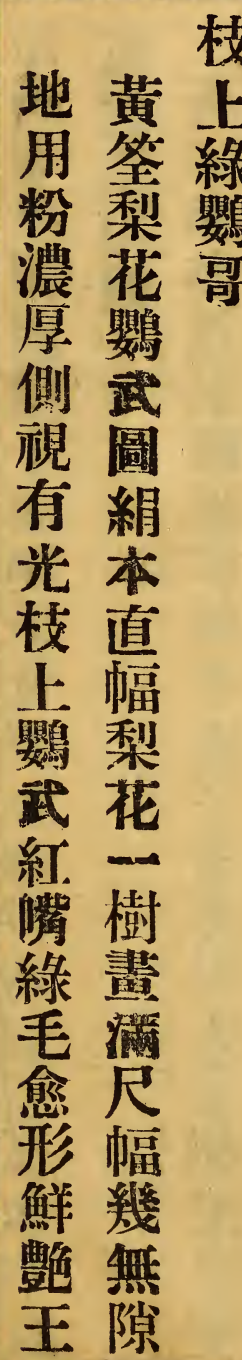 & 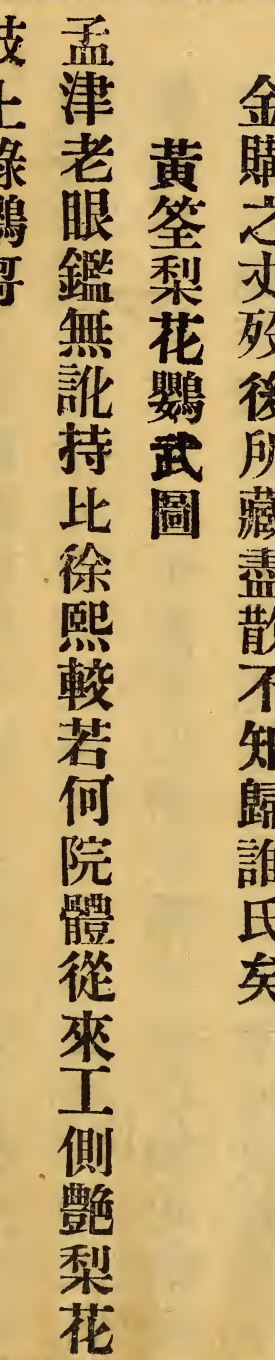 & 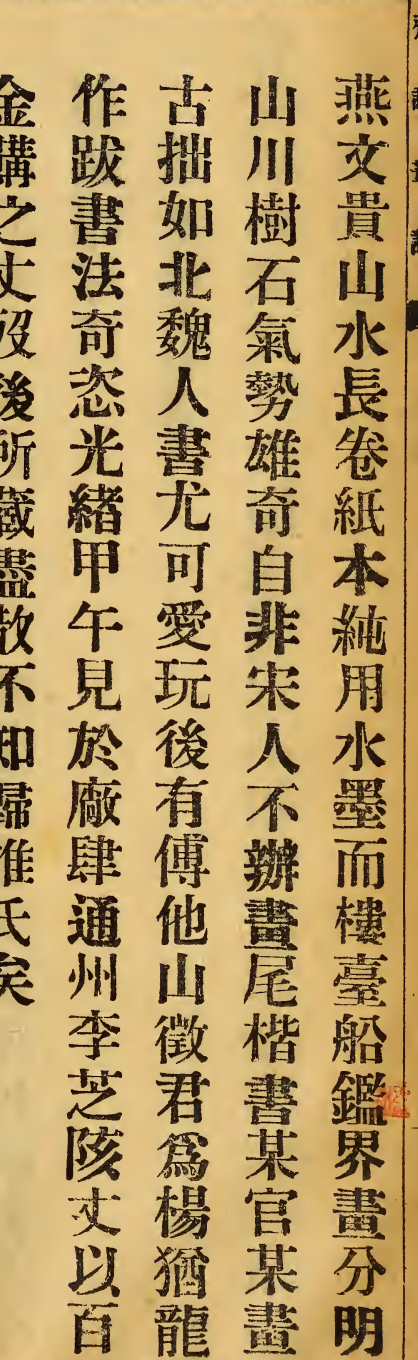 \\
\hline
\end{tabular}




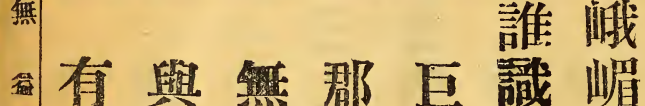

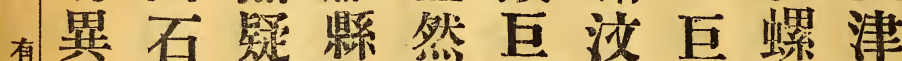

有 2 出

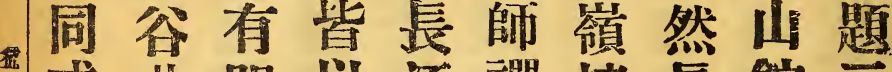

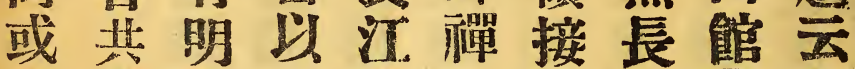

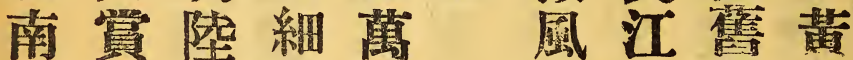

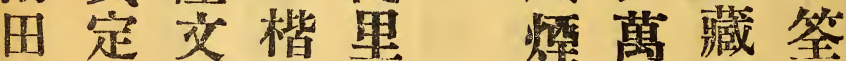

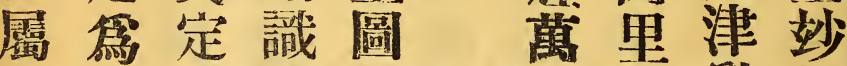

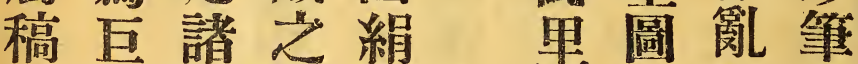

III 然

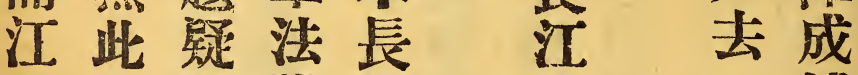

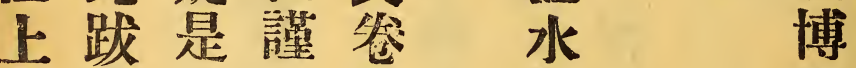

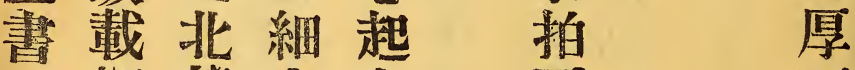

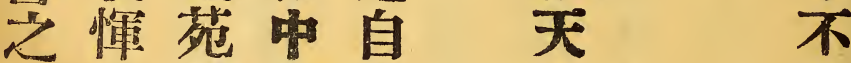

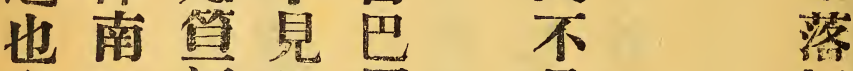

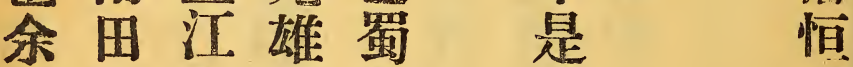

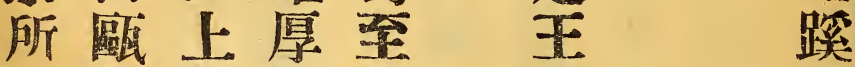

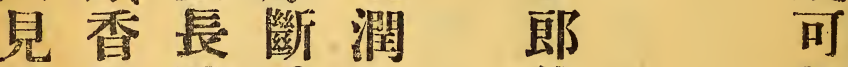

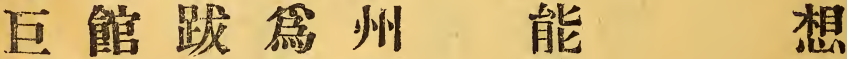

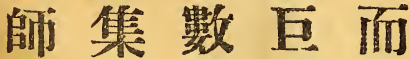

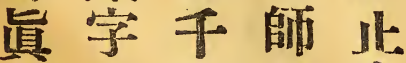

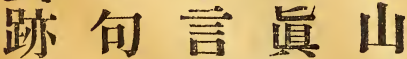

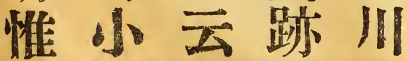

览

梗

I $\quad$ ty

Hi 5 


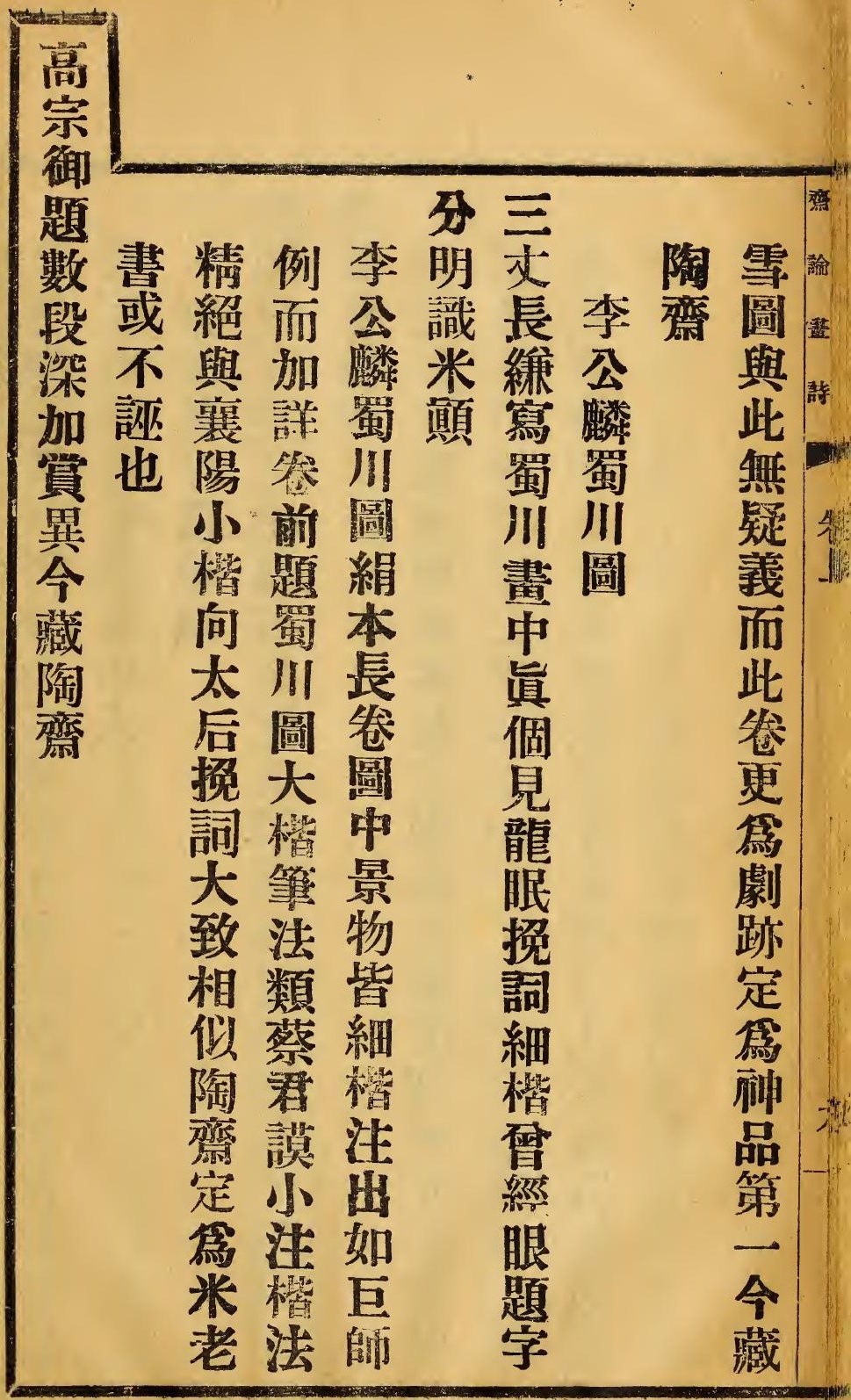




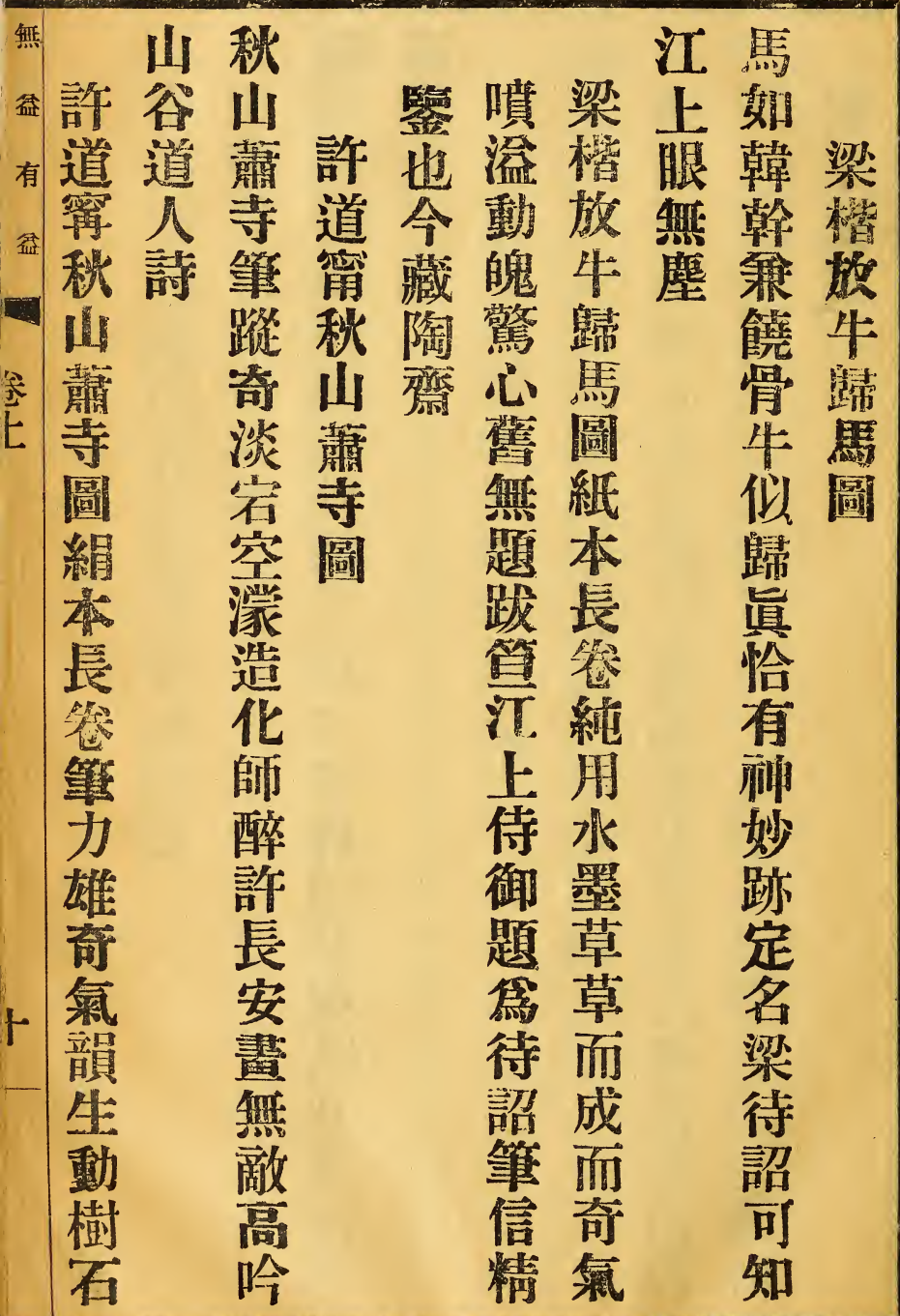


至筫如商

今山鈰邱

高 積

憶潅隔策

水㸆

水水卒

間綾康峰

堂筜

渵六翼

寶

元上者積

光王明雪

縉孟昌圖

初津題絹

見行留本

月 峰

寒

寊

落

范举題抹

賽積識如

瞫管芜生

賏 書生:

池圆 法鐵

㩆

蛋

字

於畫霓大訣

大題䔬幅交

粱識峰

脯歏稚

真等

安

科

頭

甚 鑄

精 成

索渾圖

散

貲厚

萻華字

未濼於

能如上

䁲置字

得身具

髮

卧

其

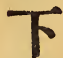

A 照

咓战夏

降 틀

驾 效

$\vec{z}$

祇

形

自

揾

不

懔

燷 


\section{宿堂}

脽脽譬堂

陽部五

意五脽

活園 老

陽

紫重

活

㫿

陽

北

笨

元

明

碱

彪

素

㻦

瑚

著

錄

録盖

炡

赫

然

㳟

枌

王

趿

霞

渾

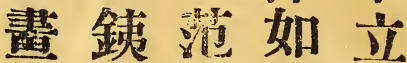

- 錚

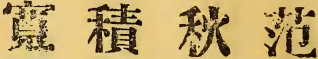

奇崖秋鐵山营

余七川幄級

族字圖

大曲 級

梁 鮮庼

冷其本

莄妿 璸

攤小维

上 㫮 罍

得如 氏

之禁故

亦粟物

失而素

於酒津

拳晋題

此如云

之䇡 用

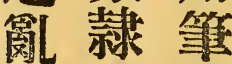

矣 與 㞦

汇 積
扇山

本 圖

past

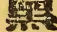

+5e

正:

玩

到

It

B

pij

ᄀ

IIII.

渥

細

fy

妙

题

मII

슬옹

法 
妙

絕

希洛公襄

河 郭

世的字髹

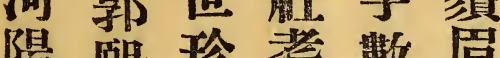

陽熙珍意數首

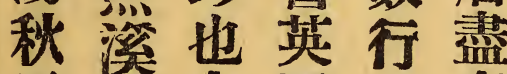

需剀含圖

卷秋藏絹

幾震陶本

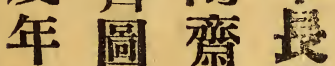

流

落

在

江

ㅎiㄹ

할

市

中

張

$\Rightarrow$

焉

4 itif

iti

4

जi:

IAP

해|

物

鉒

北

株

原

本

部

約

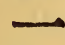

है:

茜

文

II

手

且

到 不

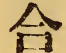

解

洛

府落

配

㫿

陽

焚

竾

香

百

拜

才

舒

突

䉆

書
章 梁

解 15

人 得 侍埳

洛 琴 復 御

杜 そ敬 遊

赫

公

皆見

余示

執題

友 名

相册

繼尾

淪 後

謝 霹

迴 盛

憶伯

此拲

国然

回

曷酒

勝 所 


\section{仍 針}

所罢遂彩

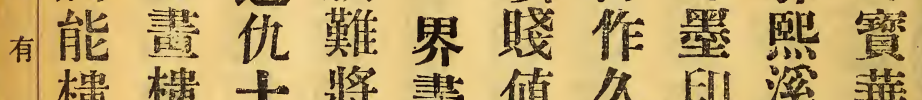

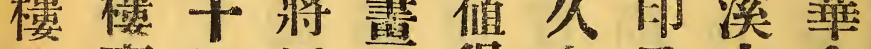
上豪洲界樓得在及山畣

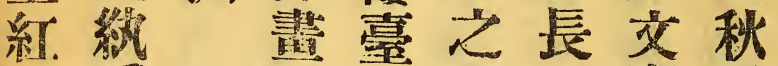

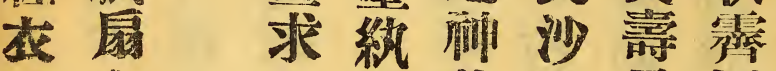
女本千扇物市承圖 子 蝫

阴

得上諸絹

小欵

所范跋本

如 識

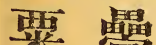

稛量

米閣

萬

Fi

喰

迷

意重

態 榱

坐簐

動 如

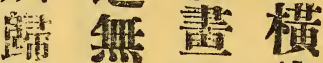

矣售石管

者如香

榱

I

夫

不

疑釷减

出镠郭

鬼似忠

工非 恕

北界魄

策踾

力

陶焉

嘿樹 珍

佾用賞

畵蟹㟲

一匹見

見法題

歏河識

篇陽有

南本 柯

珍色儿 
畫

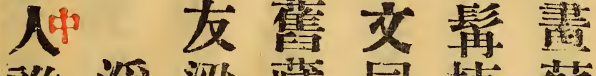

梁

誰源梁藏

識休節面

栈

休

钣

百

同 棲 蘇

堛盾 題

澡子庵刻

榴

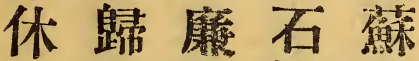

子牧訪置㽣

歸 圖所㢈題

牧

圆

成

只

自

看

面

似

詩

人

題

漫

與

何

䁌

得 雅 声

堂 符

壁 題

題 者

咙自

多

名以

跡下

未 數

监

刻人

收

今 海

雹 扎

余氏

一畫礓 作

壆竹藏宊

噍蕉 今王

後軾失居

來題

學 請

者築

只

州

邱

修

傝

數

筆

如

䜌

Jiv

$E$

螺 後

山 整

墨
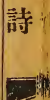

d

veta

津

IIE

题

云

持

比

郭

中i

必

如

怒

别

具

精

維

綪

信

然

合

斯 


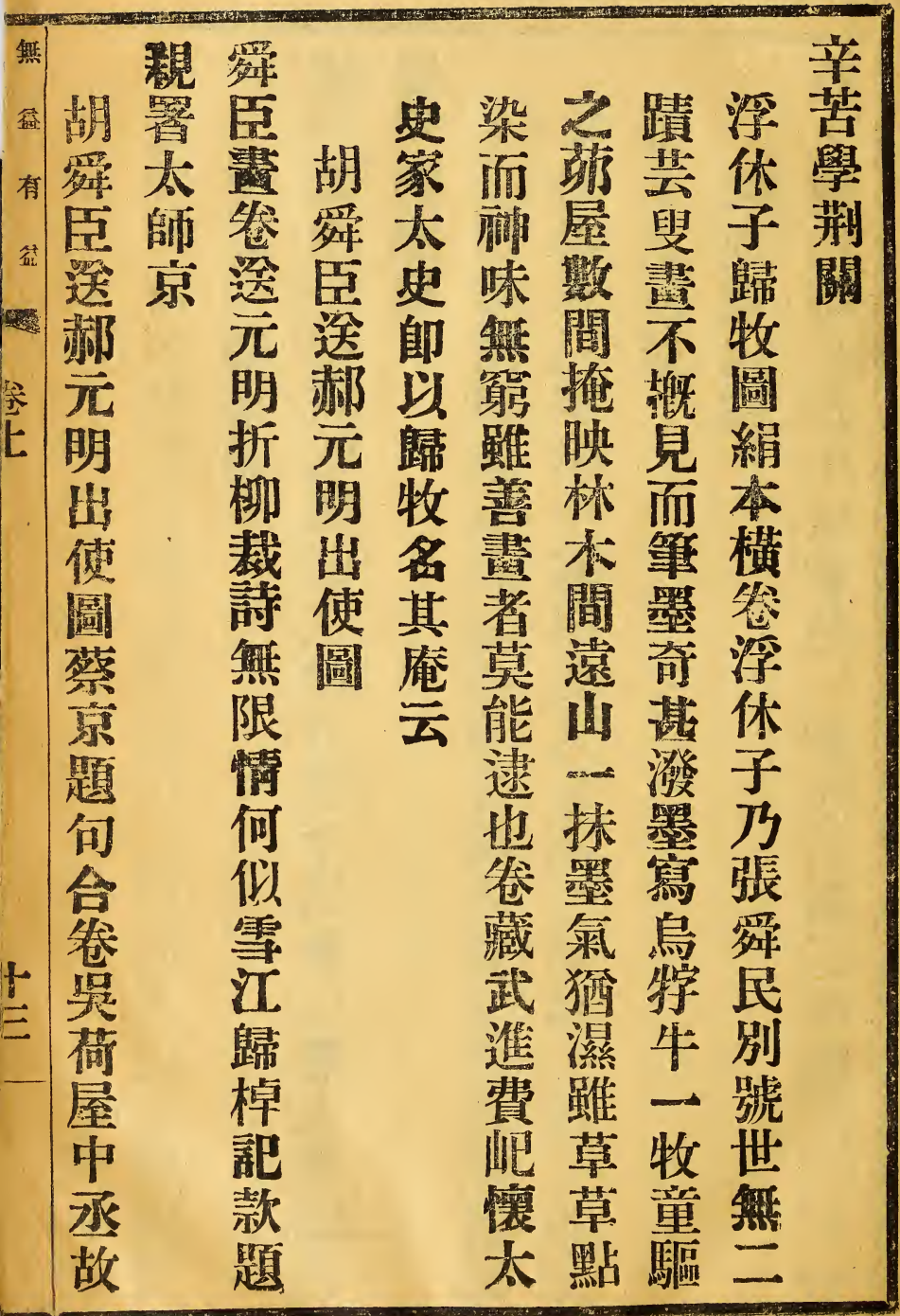


復扁檻

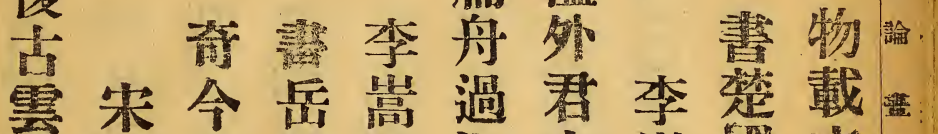

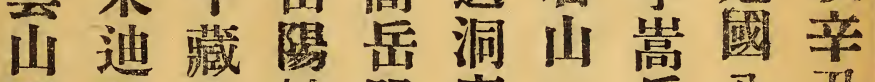

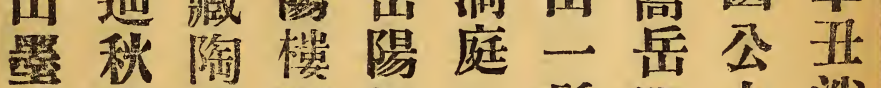

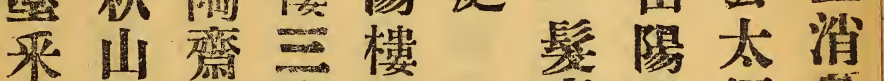

垣:

字 圖

莝 絹

中本

客直

四融

无. 粗

縑

八 筆

氮界

韻 畫

坐古

動 意

栕 留

檻

上 然

䊢 梙

一椐

猿署

管

毒 簑

沅 圖

闌

湖

.

iI.

動

師 皇

토

京往

與 見

此蔡

熒京

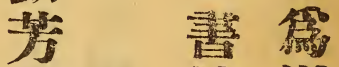

警法道

李 正君

禽同作

妙 故管

處范江

無 そ 歸

人

會

憶

合棹

藏 圖

陶訅 我烝 款 


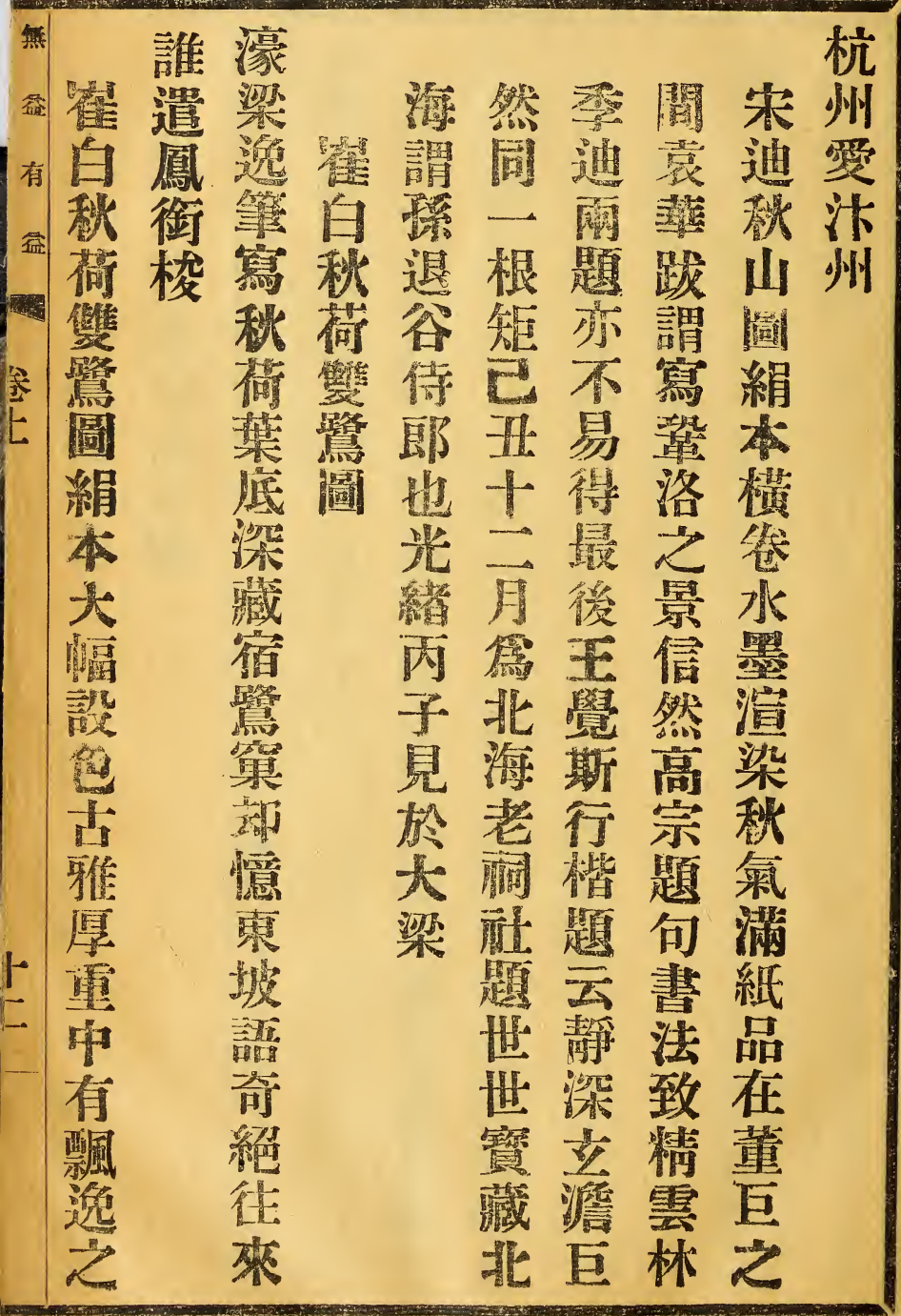




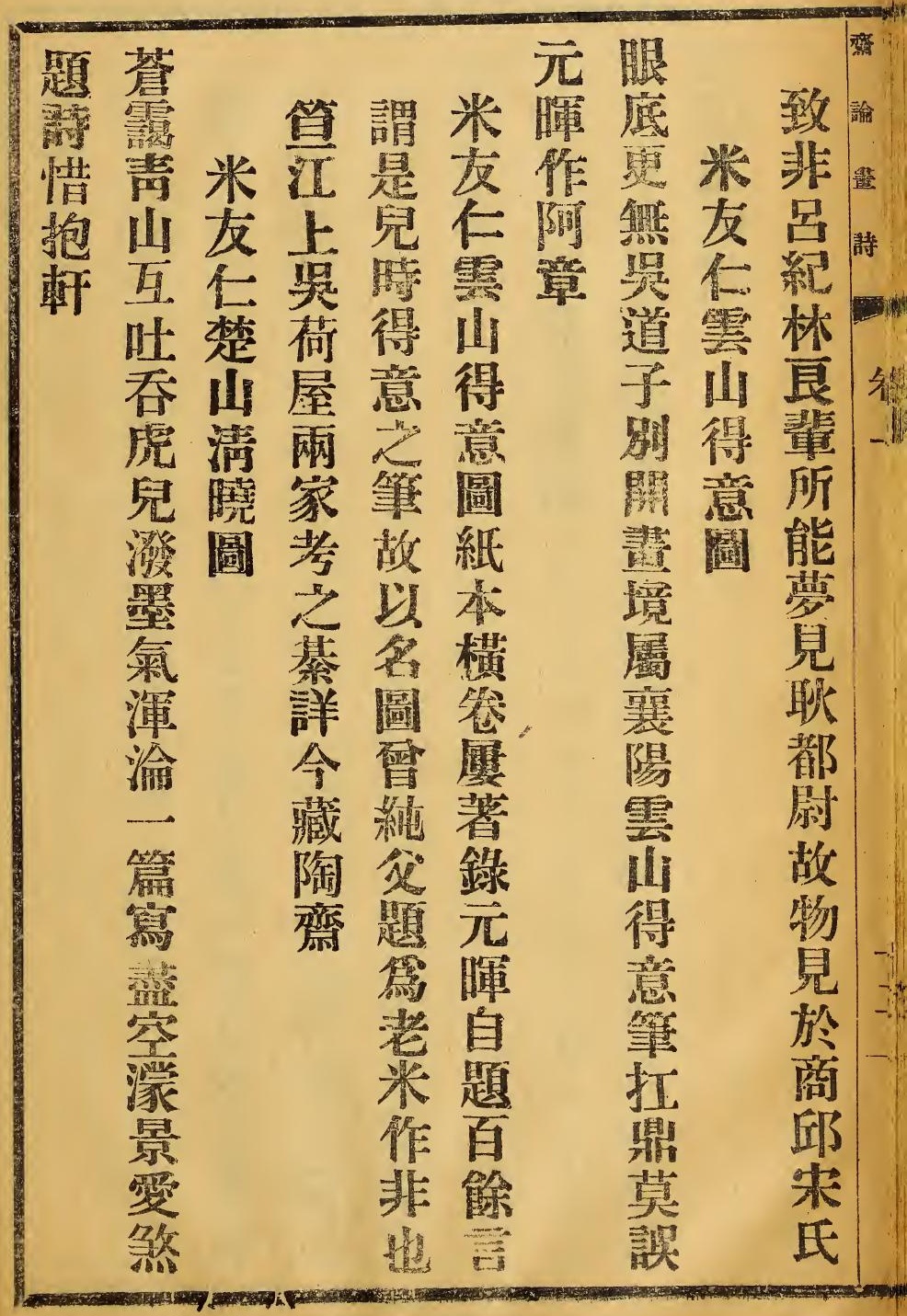




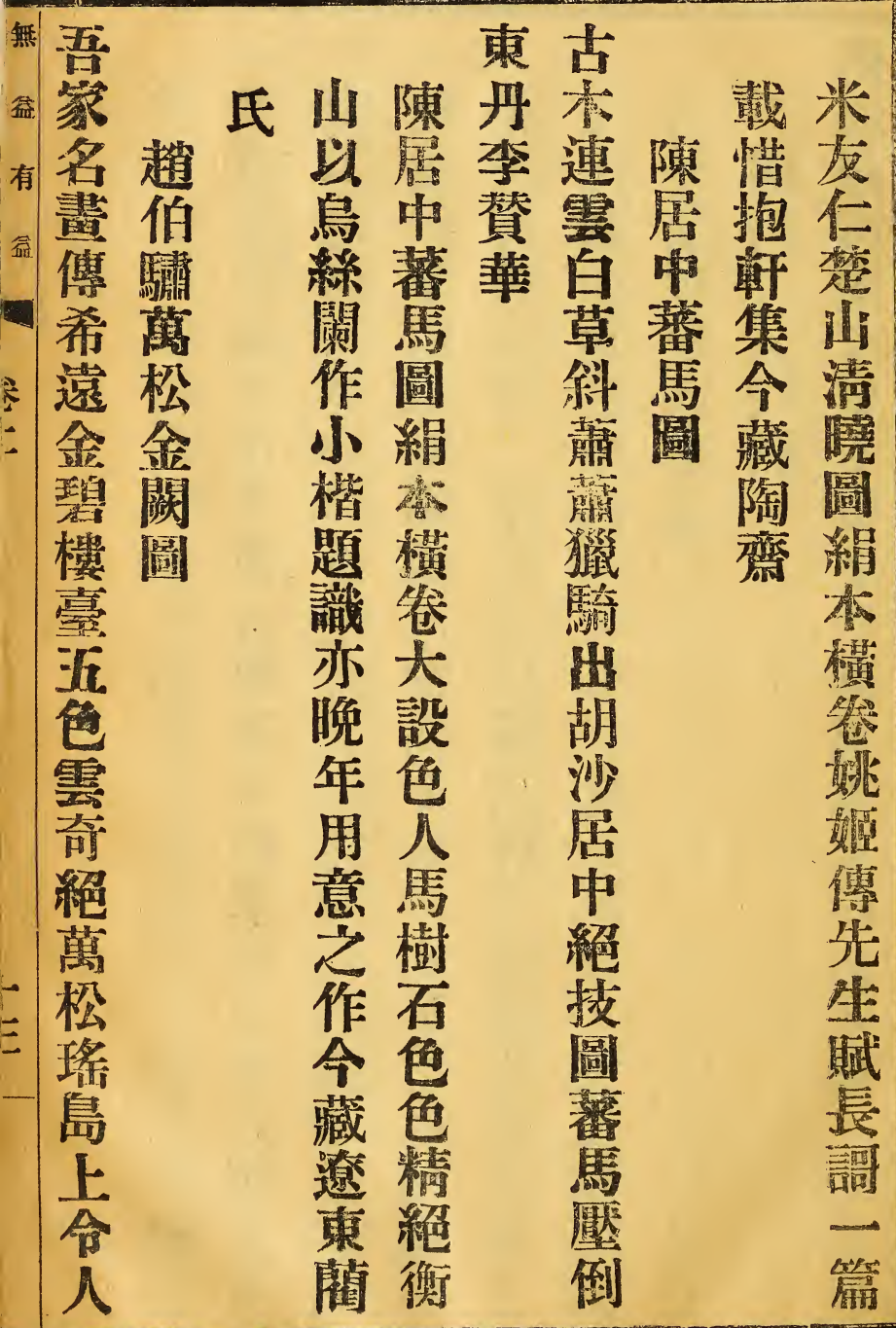


侍 郎 碧殆亦疑鹂 南 源

:

鳥

和

徒 毪

不

以. 趙 刑伯 燃 後

撅

䕬之睬史

圖

吾

䕬之睬史

家

大

可

緑

魂

䋑

稱葛我

湍

故 將

散

物

睛今

也

蒙

恩

홍

गय

國

風

訑

得

葛

覃

圖

答
奉
華

世筸

二太題

十丠行法山本

年以楷铺間 蓝

末 眼 糟趙雲 先

見余紗漚氣楅

此姊與波粉閣

圖 尖琶題筆 純

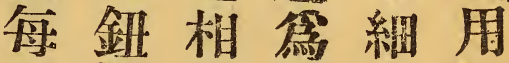

一润葐希勾泥

憶生雲造加金

及學林箐以傅

唒士題否花任

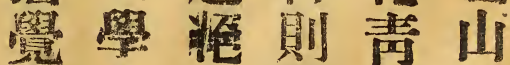

金士句轧奇

却踏

谣

过

4 点.

71.5 詩

I

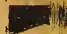




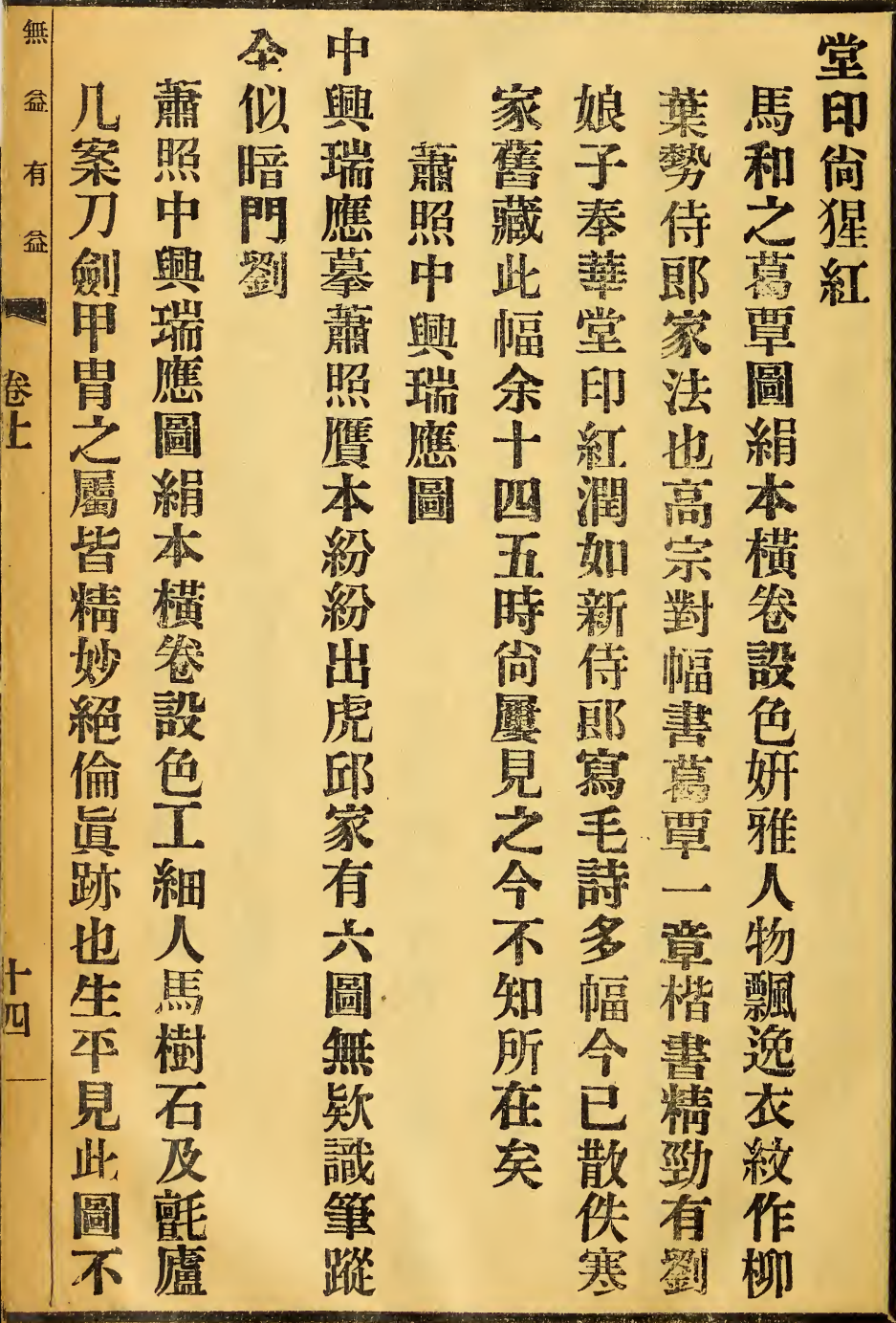




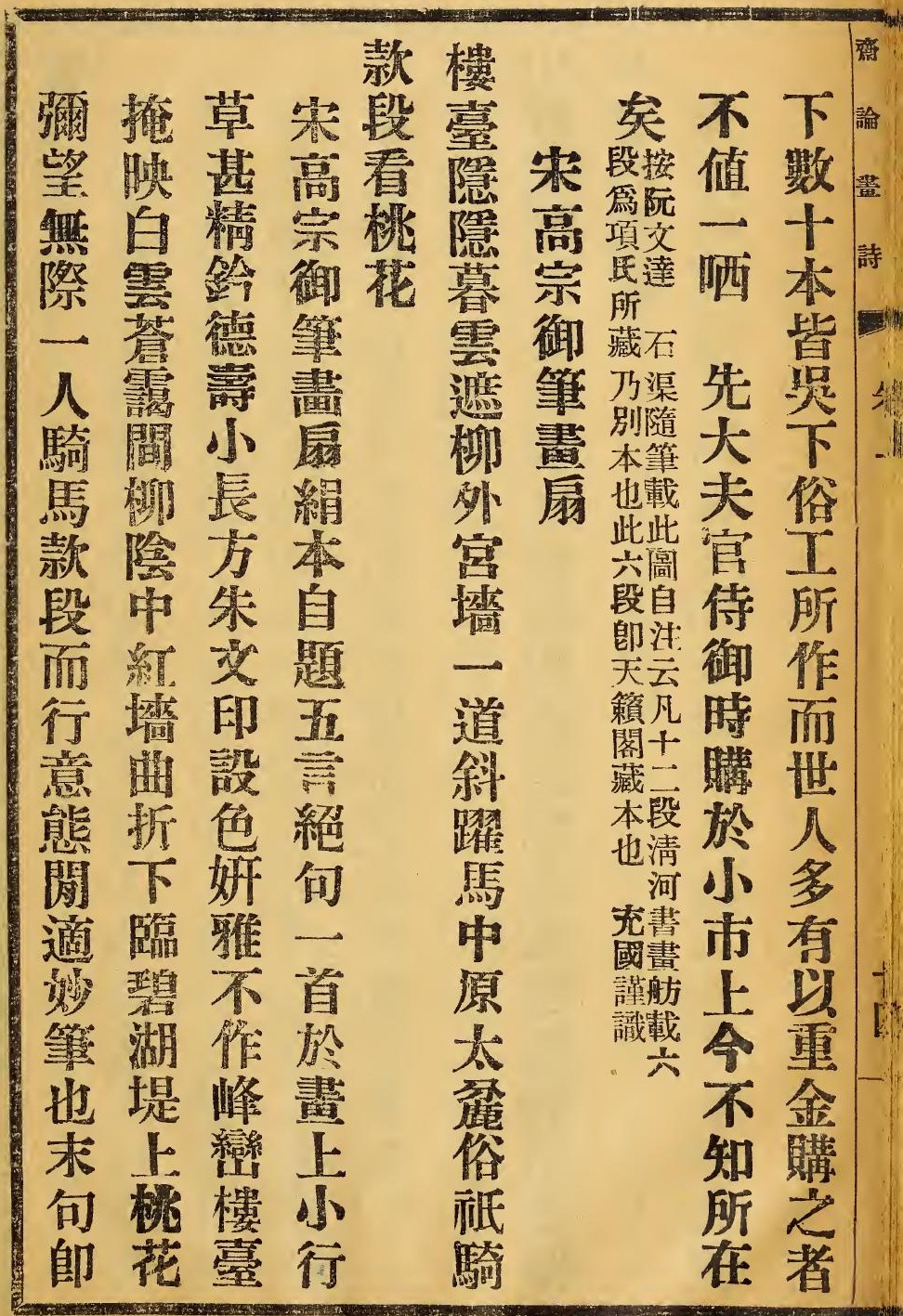




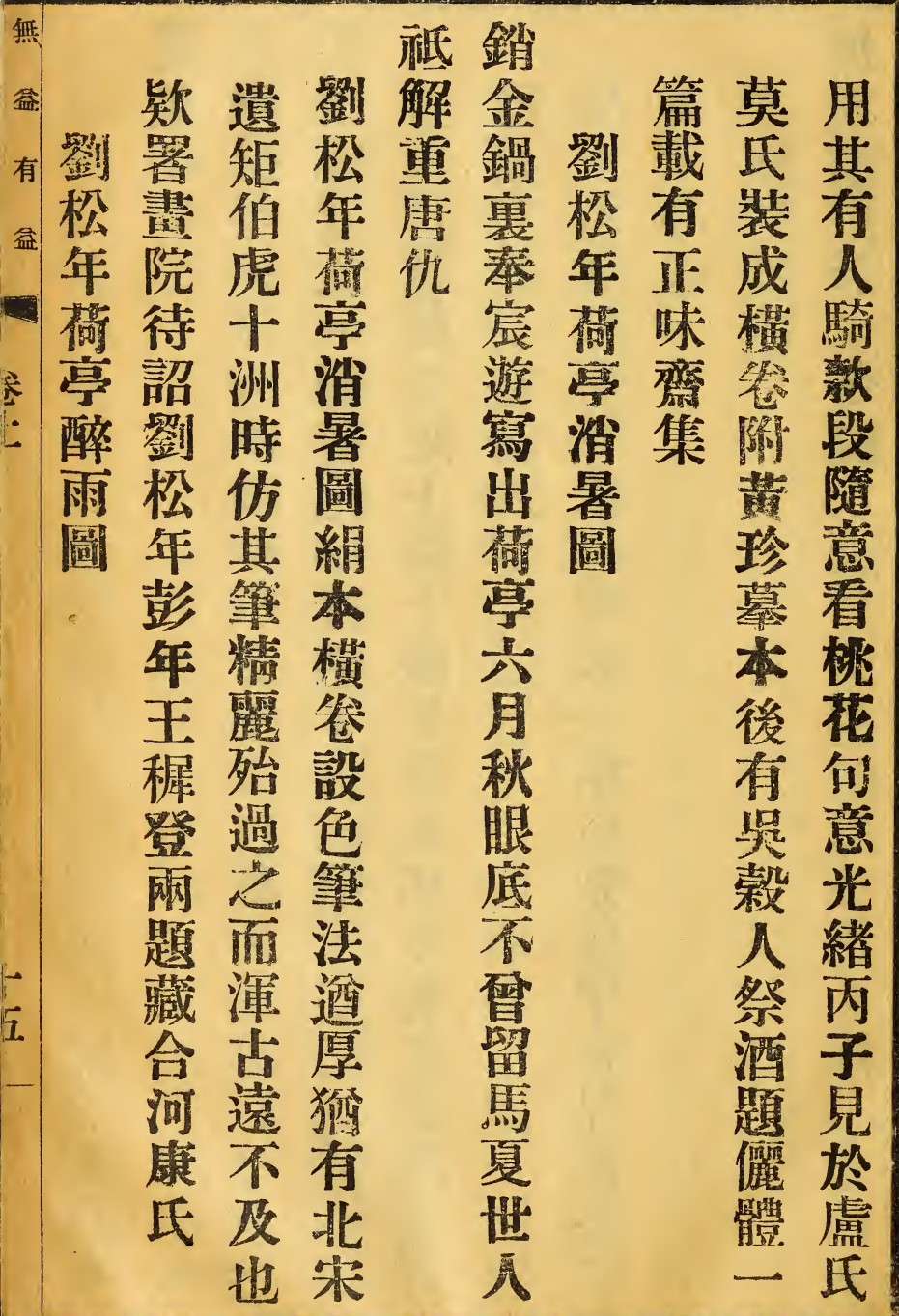


何

來

雷

雷

雨容命渻宛意五年絸

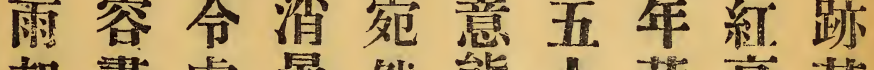

英题雨旁坐劉裹年

花松倩

起畫處暑然態人嗃亭若

老龍

圖 只如一票

摹䆓生著醉

劉錢䔶黃雨

松豰上袍圖

年等柳 如組

或題十王本

又咙馀者立

一霄株手軸

本見隨持設

出伯風巨色

业虎捁触堂

光虎搖解禹

緒蓦曳女葋

甲本葆子菲

蜜布葉二童

見置雐入有

於二翻捧总

陸同䕈喆翼

子署舞尊然

晨

星

畏

傳

摹

锁

典

刑

型

何

似

哭

王

溜

消

暑

虎

蔦

草 


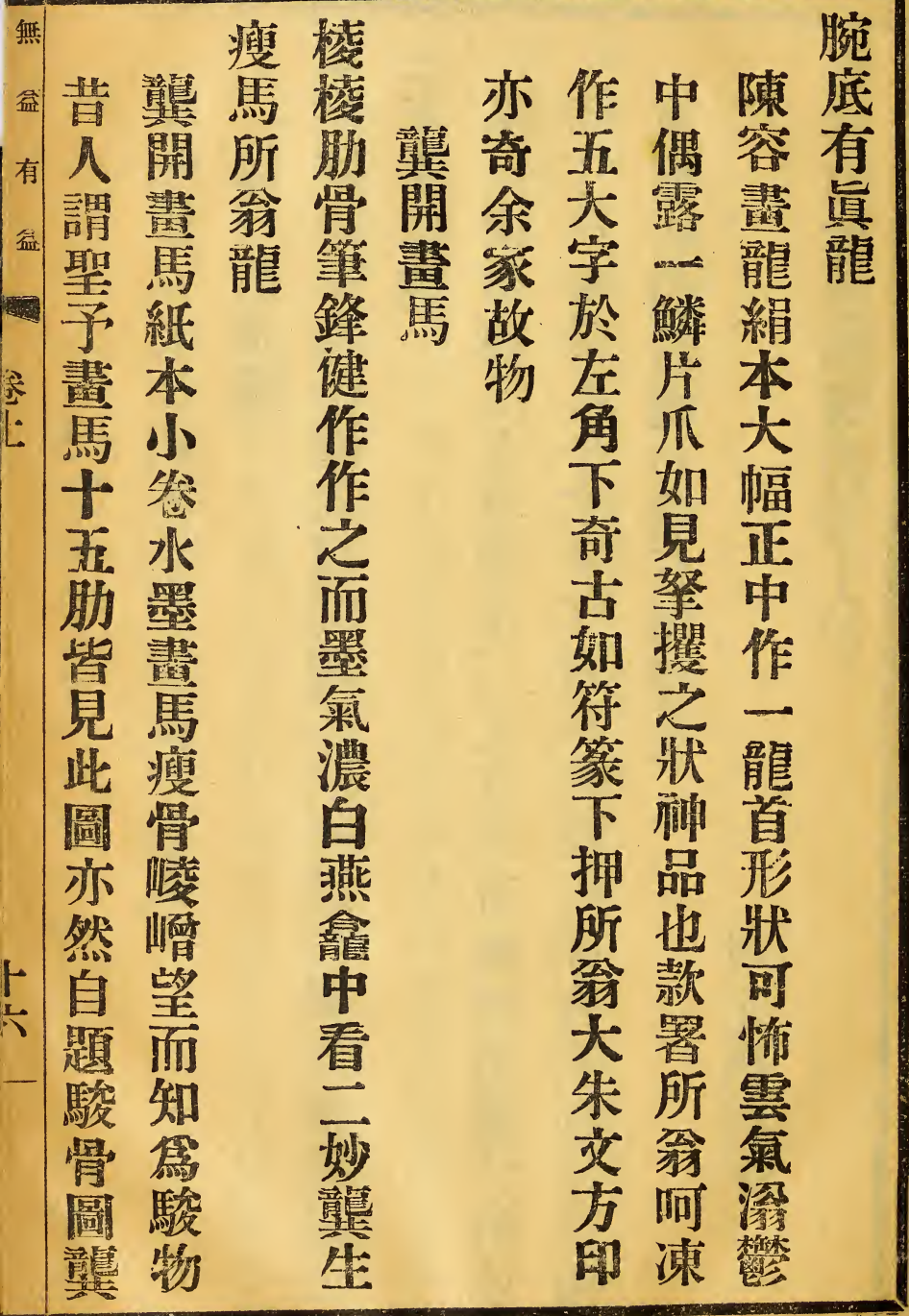




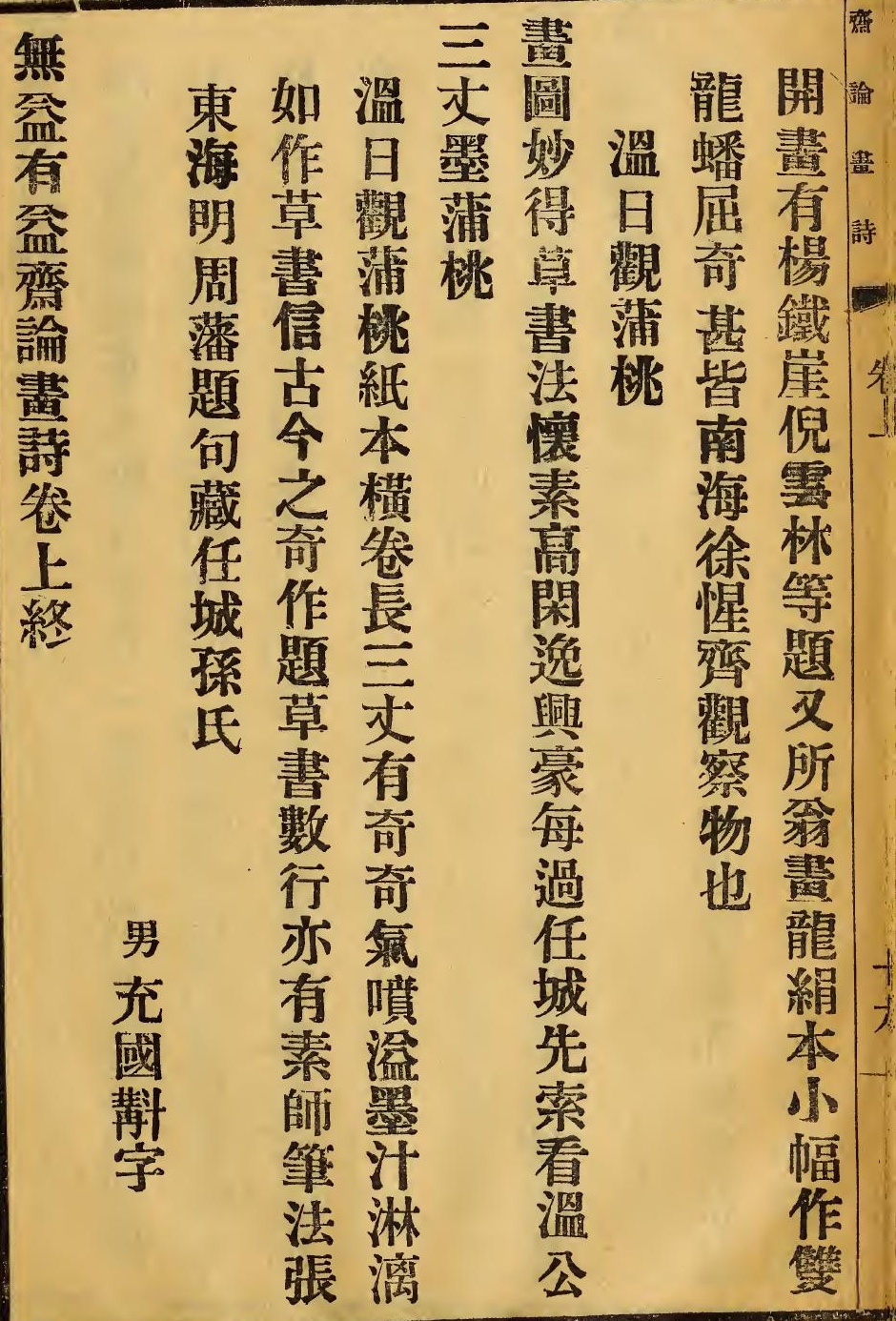




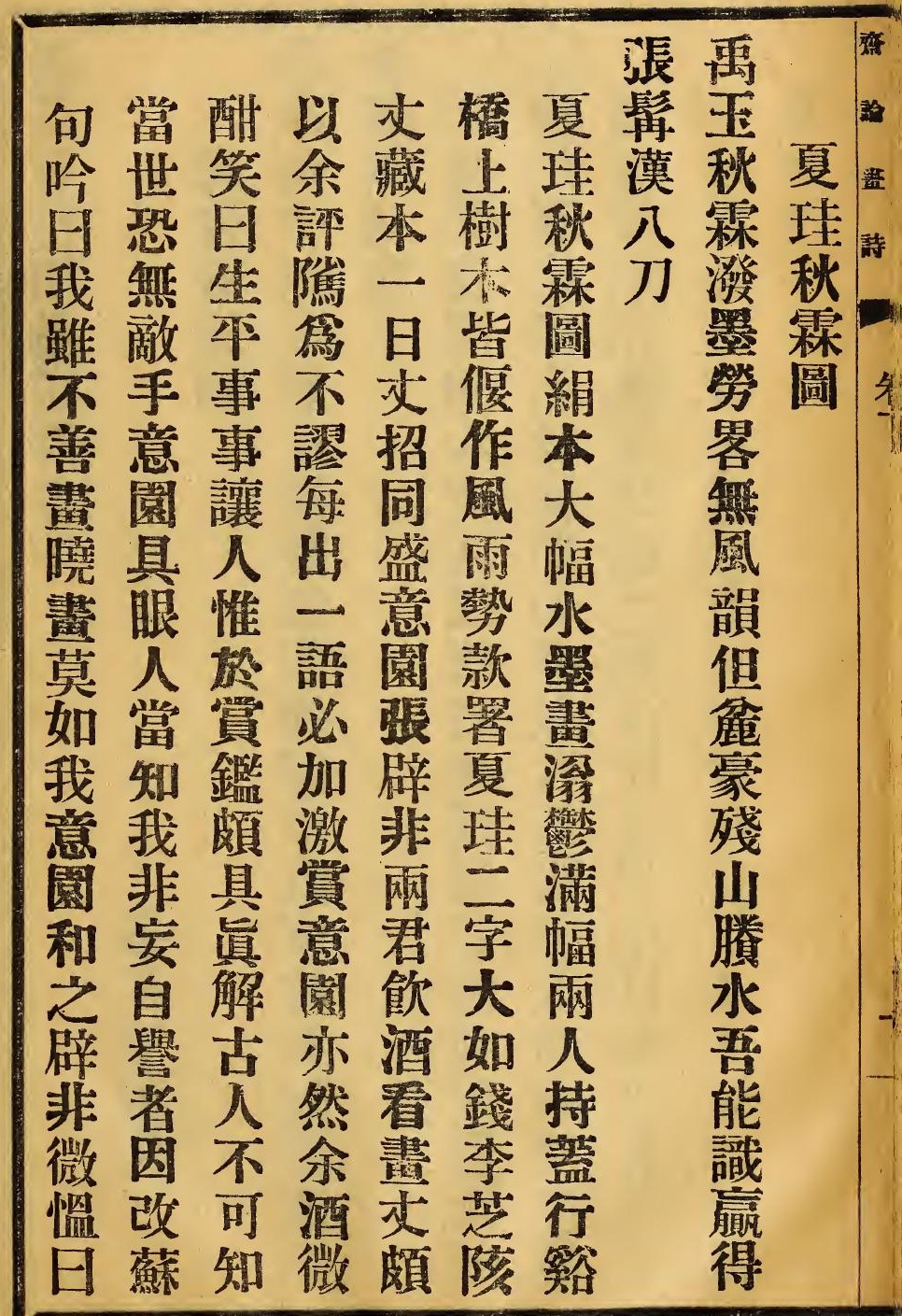


無

鼓取定馬見有雼所定君

有掌漢唇是戀謬証佩評輩

笑入則夏頭詔人王余互

日刀見莫余君此翁亦相

何佩樹作師輩㦎仲豈標

如之摸日如款所妄榜

辟日一機此何任謂歎不

非渪三語非余下漢者畏

強王株余馬笑方公辟旁

日筆可日遠百荻召非人

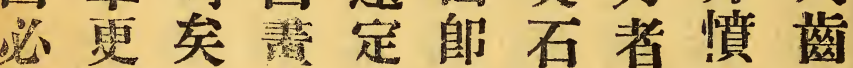

待無及中是執果置然冷

看疑展省夏餐能几拉耶

人義半人珪閒知上丈意

物趣幅物强下是百入園

始觀至否枵何誰哭室正

知款持若然如畫此取色

是字籃有復於便笉一日

夏果雨人間是任質畫此

恐然人物日屡取煩出事

㺟意余更筧畫去雨因類

非图便易是甫倘君解有 


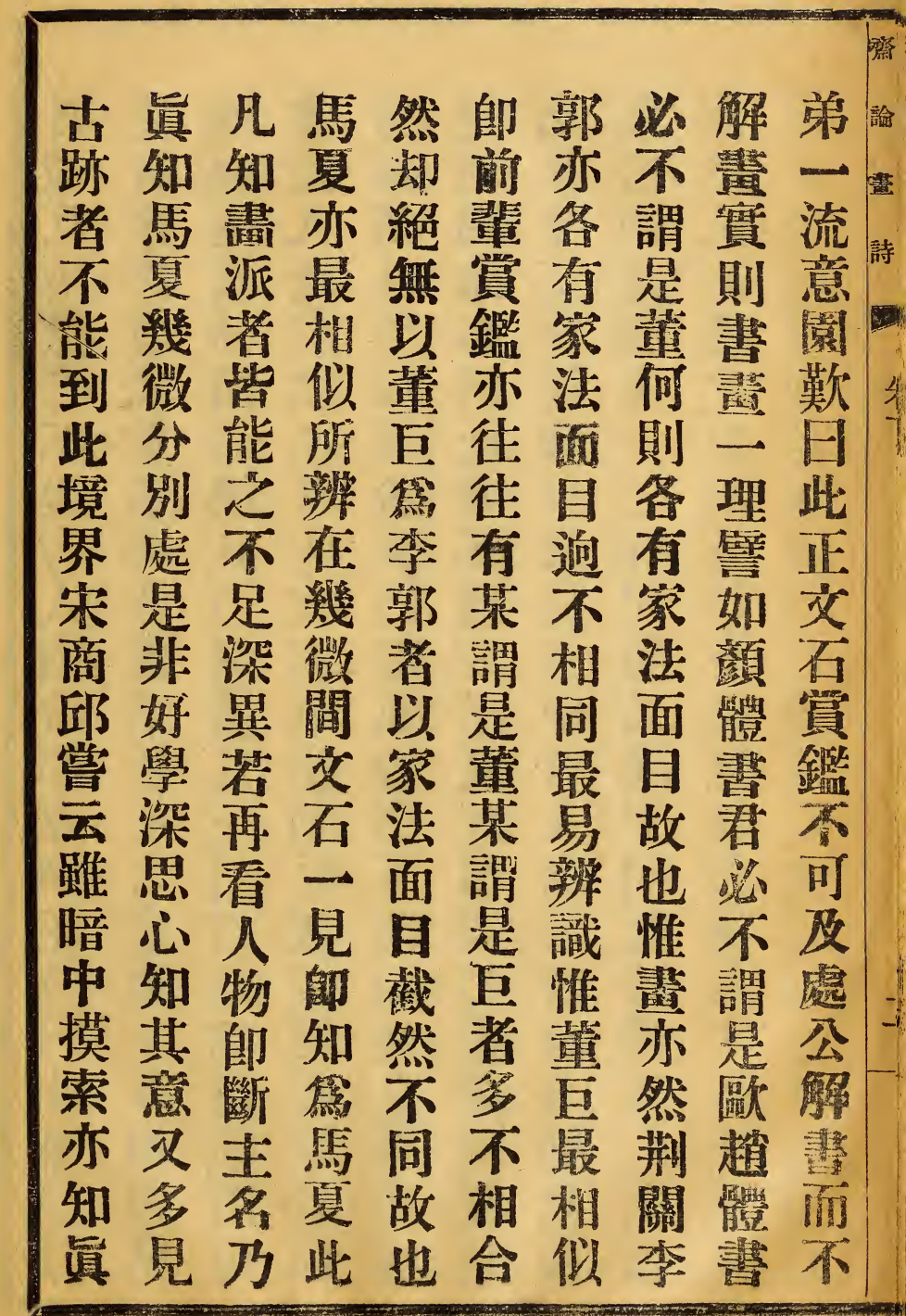


子

益母

有牛李

過畫足屏

而苂遜䉪

腹察存茂能石古此

嬉梅痛有覀在所貴人語

徝

涉子

泚

入

沾

河

觀

鑑 出 太

草母筆微沾北即得落誇

棉

中 牛

脑

處

以. 時

牧 圖 然

非

此

余自

所喜

及誨

图多

以 不

入槂

咏无

今不

三可

清䉆

皆訓

一輻

日

師夏

獲嫿

阙

所

幅

知

見

意

園

下哣

命 不

作 z敢

疏舆倨

證简 晋

而屋赤

谷䧳與

亦高楩珰

今

其一此

眤餘則

跡

槕

可

存 话

A

世二畫

作 惟

份

面

古意

多

目

話

不

人戚

本

許

遂

知石

果等

如耳

何未

耳唱

車論不仙饮目遽 


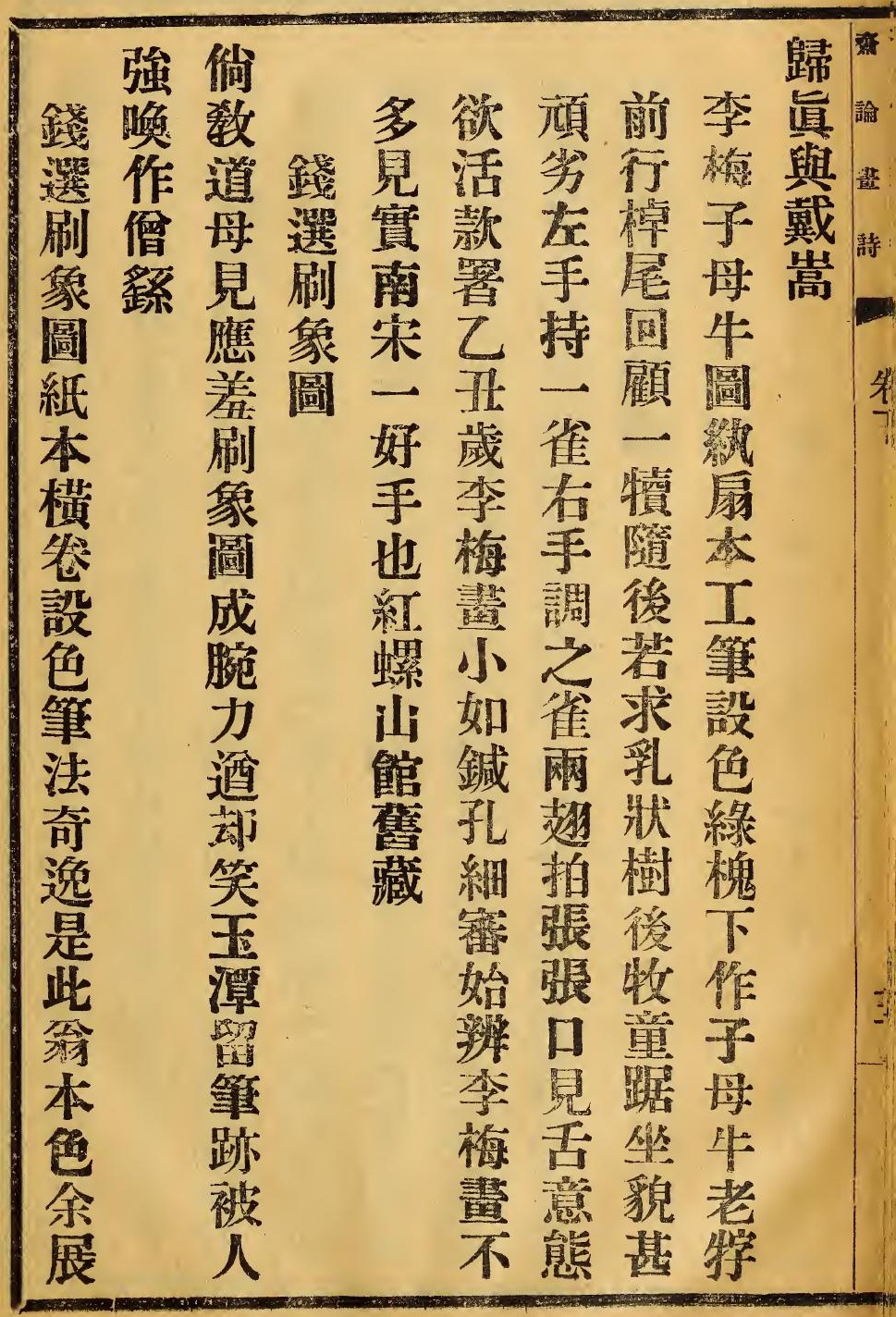




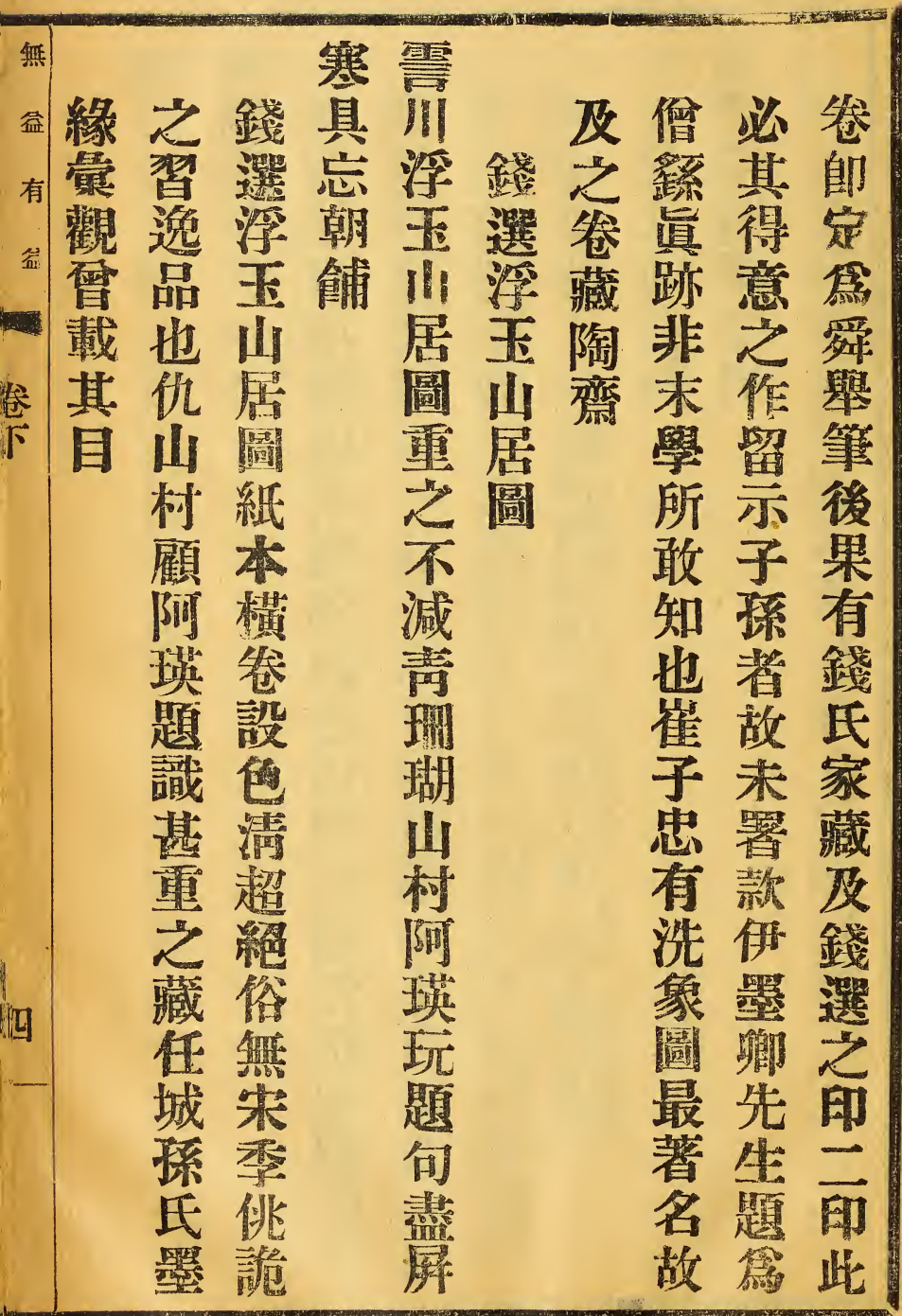




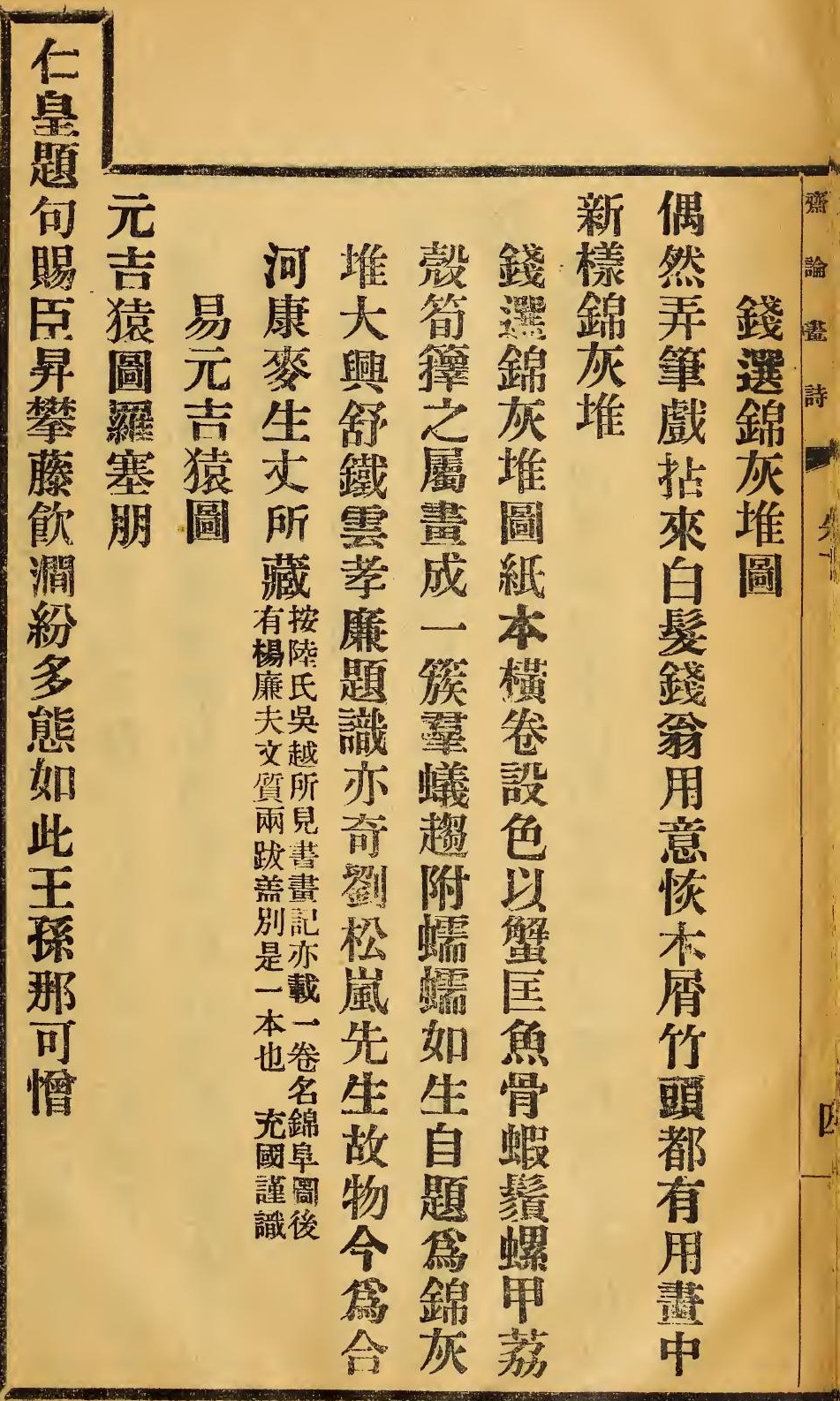




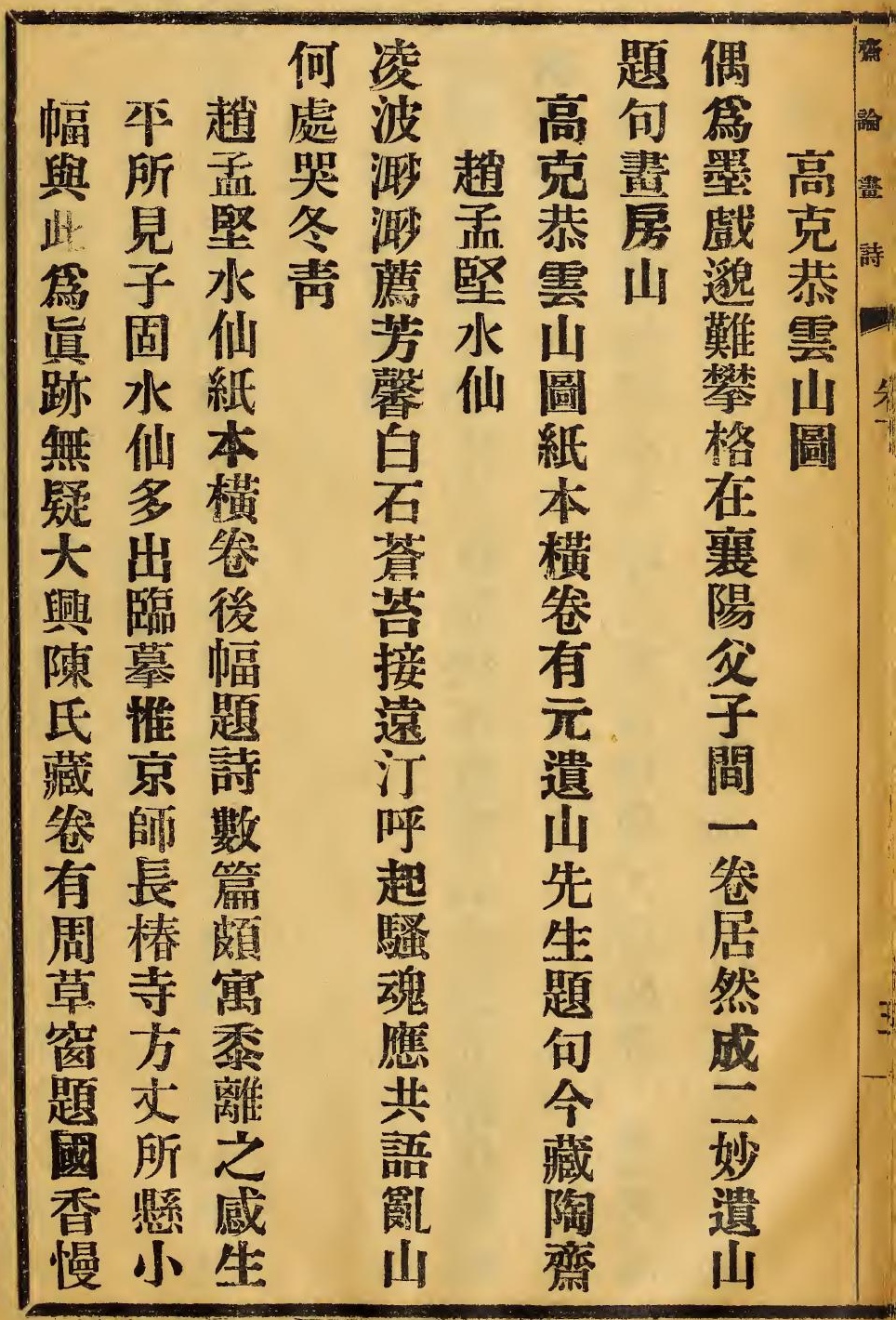




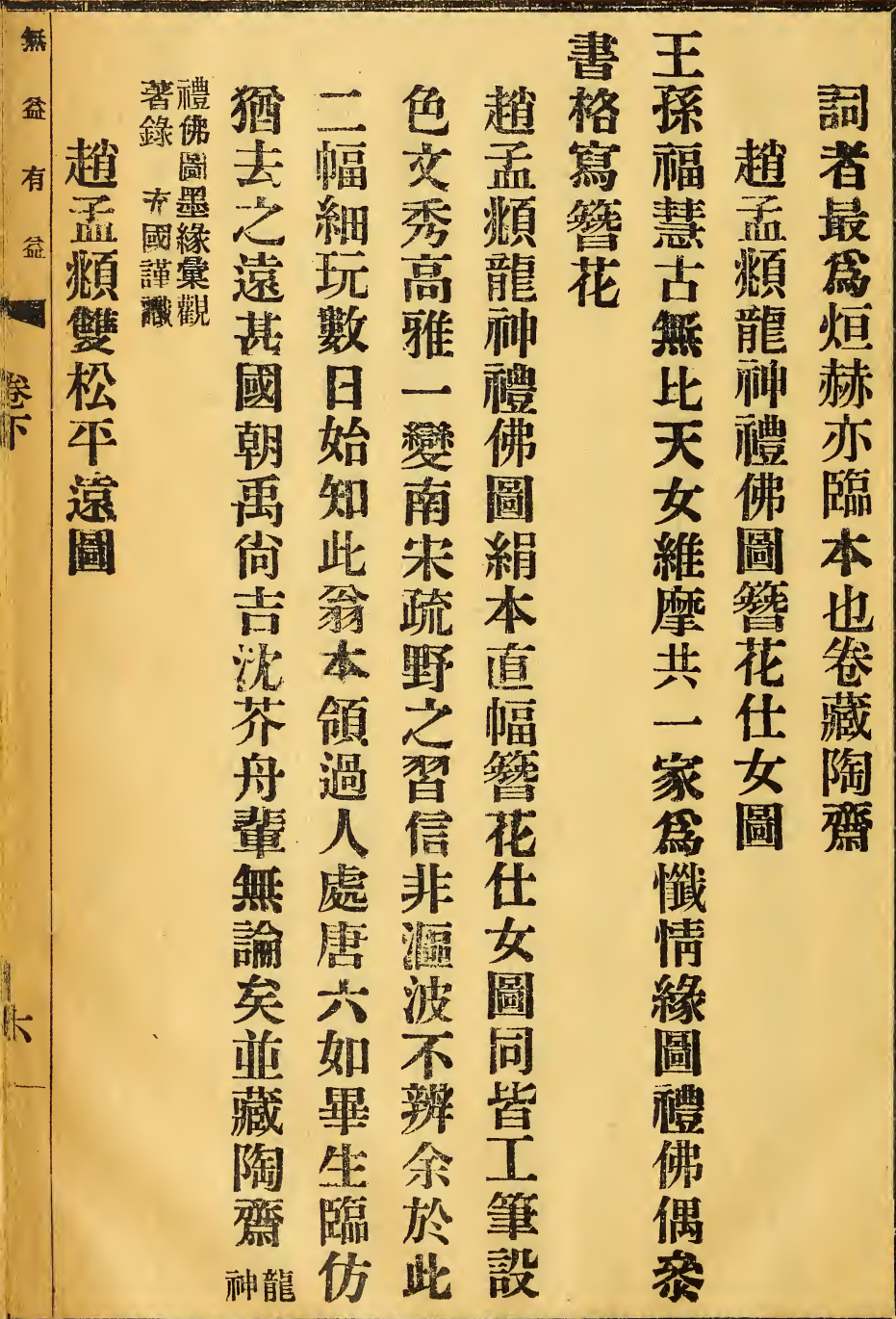


酒中

梁繁

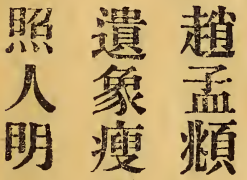

于

竹毣

第 和

識後㣂中趙

㮣 平

於見卿別孟萬山地

此舆觀源類

中察

也蕉

原利安松

柳 光

堂接

践因簏平

謂欵邨遠

子 少

和像

南

敬

耍

沓

成

把

䛊

先

雼署舊圖

董霹藏紙

椽野挴本

野雲子橫

雲作之榷

作謂调 水

乃是陶翟

知杯唯淡

其希得溒

㛭

喏

軸

f.

宣

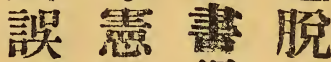

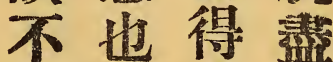

復故心恒

追有今䇛

水

光

㕍

紫

松

無

鿉

琄

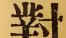

คืำ

陽

野

毁

乞

得

得

改落䁬趙

附句㬝琵

tian

波

筁

$\rightarrow$

篦 
無

徨

有

征.

㧤 司 鹳 E)

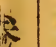

可

些菏

I플

綃

站

模

5

춘

Ef

解

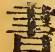

杜

ज्ञें

is

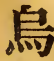

就

灌
䁰

如有

澴 澏

䞡

波

min . In.

案黨敬否可中

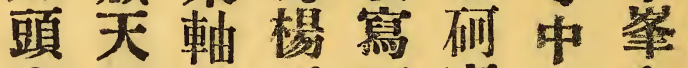

赤育子王下高峰和

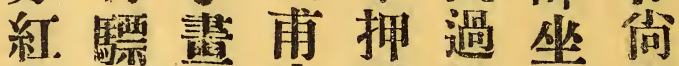

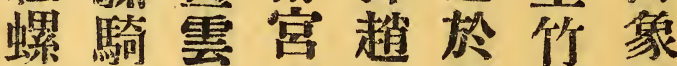

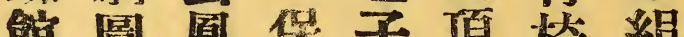

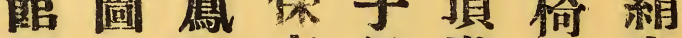

童

穖

回

看

何

期

硒

騎

圆

重

見

失

喜
精

语

菜

芒

總

的乐

谓交

後方大

不

知

在

人

閪

否生弟一步

矣得子竹法
猴 


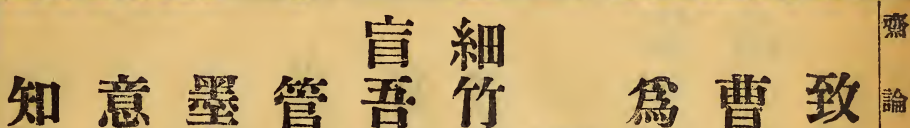

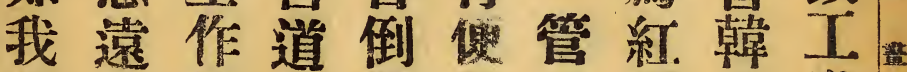
元竹昇好娟道螺余畫

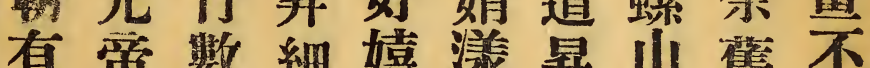
有需数細㜐泳升出整不 盖掌百竹瑟細館藏布

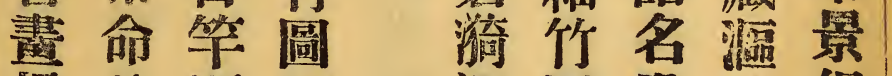
㷌 侍 漸 絹 人臣遠本 出索用橧 吾夫墨劵

竹人䫧石

房與 淡 俩

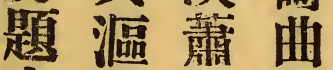
夫波疏折 人合柲下 畫作落险 倒㶳叮潖

用意境波 好白於傍 嬉 令篮岸 子後 令 以 印世人焦

深

閏

勡

寄

㯟

離

点

婦

人

善

畫

鱼

邀

天

語

語

莫

訝
畫波但

甲仿一

觀龍縕.

度眠衣

子好管

失頭官

艺赤牽

些馬

書 而

蕉

毒㽞

詩 氣

紙 逈

本出

㰏

然讓 


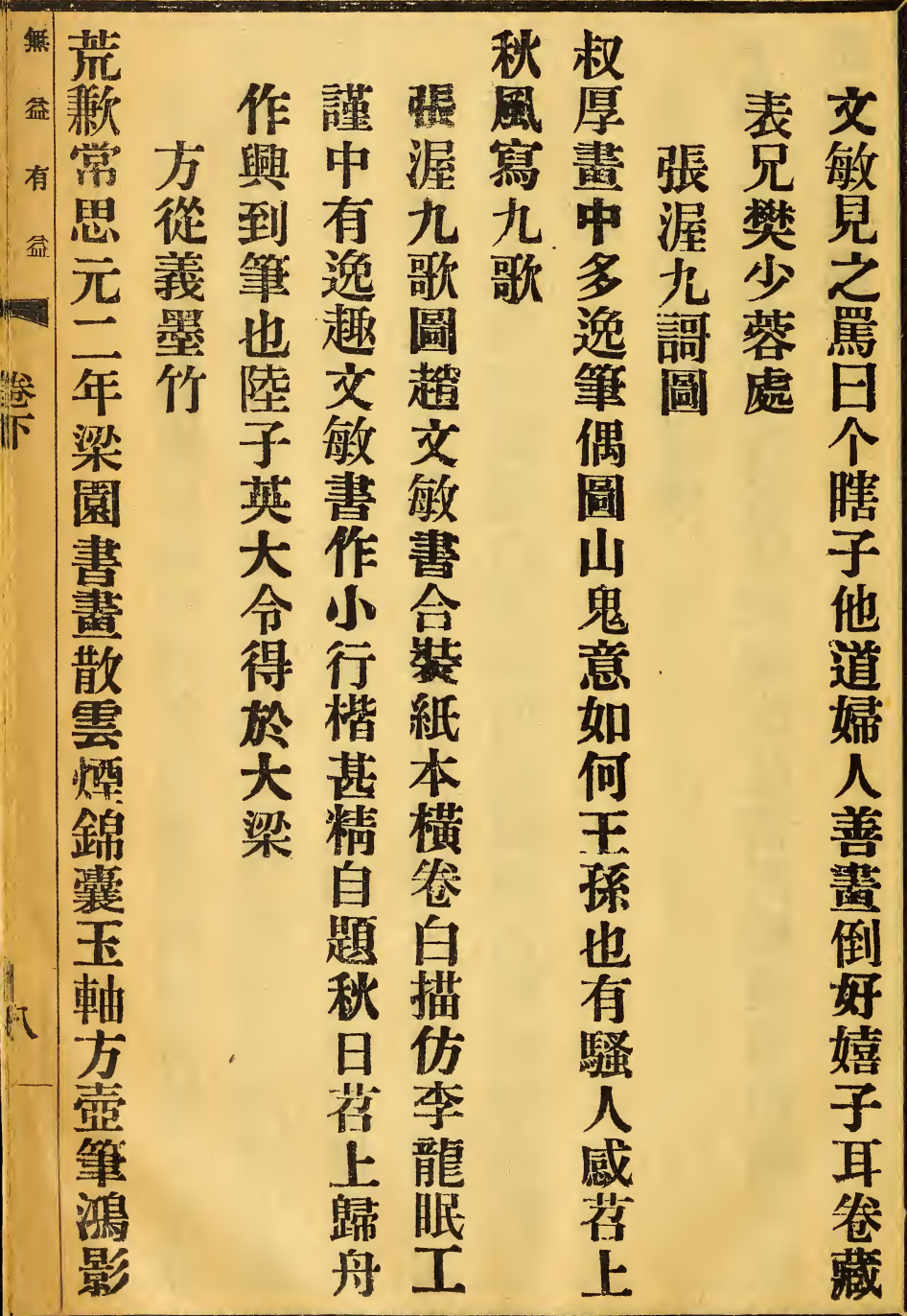


截 子

取 華

郭 老

河鲜

陽氣江

絧山

生值賣溪

唐故柔於學

少

蒼 無

物

盡 圖

II

山

接

混

要

汇

㭸

向

鸪

波

窥

畫

謨

毫

端

十 鴻

金影

$\pm$

矣庵

題

句

梁 攤

錦上

囊侐

庵

竹方市

鮕 促

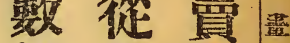

榮義

麽 哭 錢

落 竹

而 紙

遠 本

妙 面

5 常年品幅

告年喓

王賣咕如紙

碾家预自白

西 以 題如

番百饑一正

連鍇人詩罡

軸得相字色

䛧之食作楩

精余有音濕

雅聞 老草石

梁往嫗亦坡

篗觀持精一

林已此禾折

先菜軸濂風 


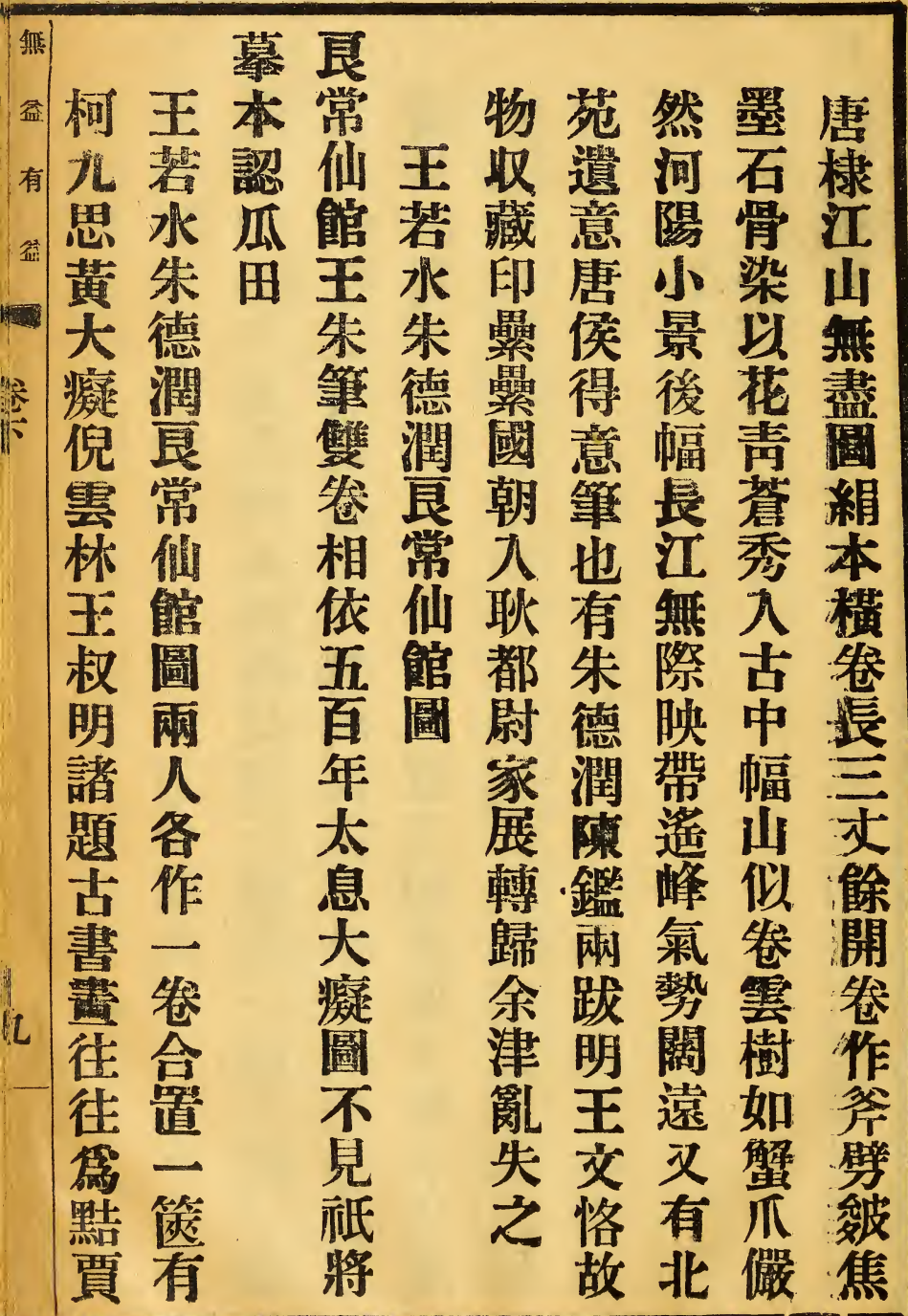


丹

邱

絕

藝

綎

胡

州

箐

法

應

從

從

竹

캐스

萌

求

訅

向

海

王

村

異

見

W

偲

人

柯

知 近 仙 款

九寡

㽞跡 區

竹否

II 淺

人綵

來 侻

自跕

長法犬雅

沙渾山雨

云 成 特

彼 繁

中 細 壁

起

都

轉

隐

士 碎 立

本

大之如在

夫留

有 想

藏 見

是原

屏

余

山

下

篒

墨

林

軸 本

者之扶幅

不妙疏署

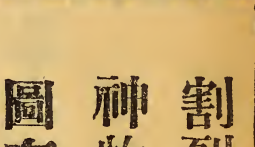

有物裂

勾呵題

請萑

ii 謢跟

外留别

题緮

度廂求

明軒售

爪攵两

題得無

封於首

最山尾

後右完

王今羓

覺歸 新

斯陶如

一㤎未

題大觸

乾榩传

隆亦所

中有謂

張 此有 


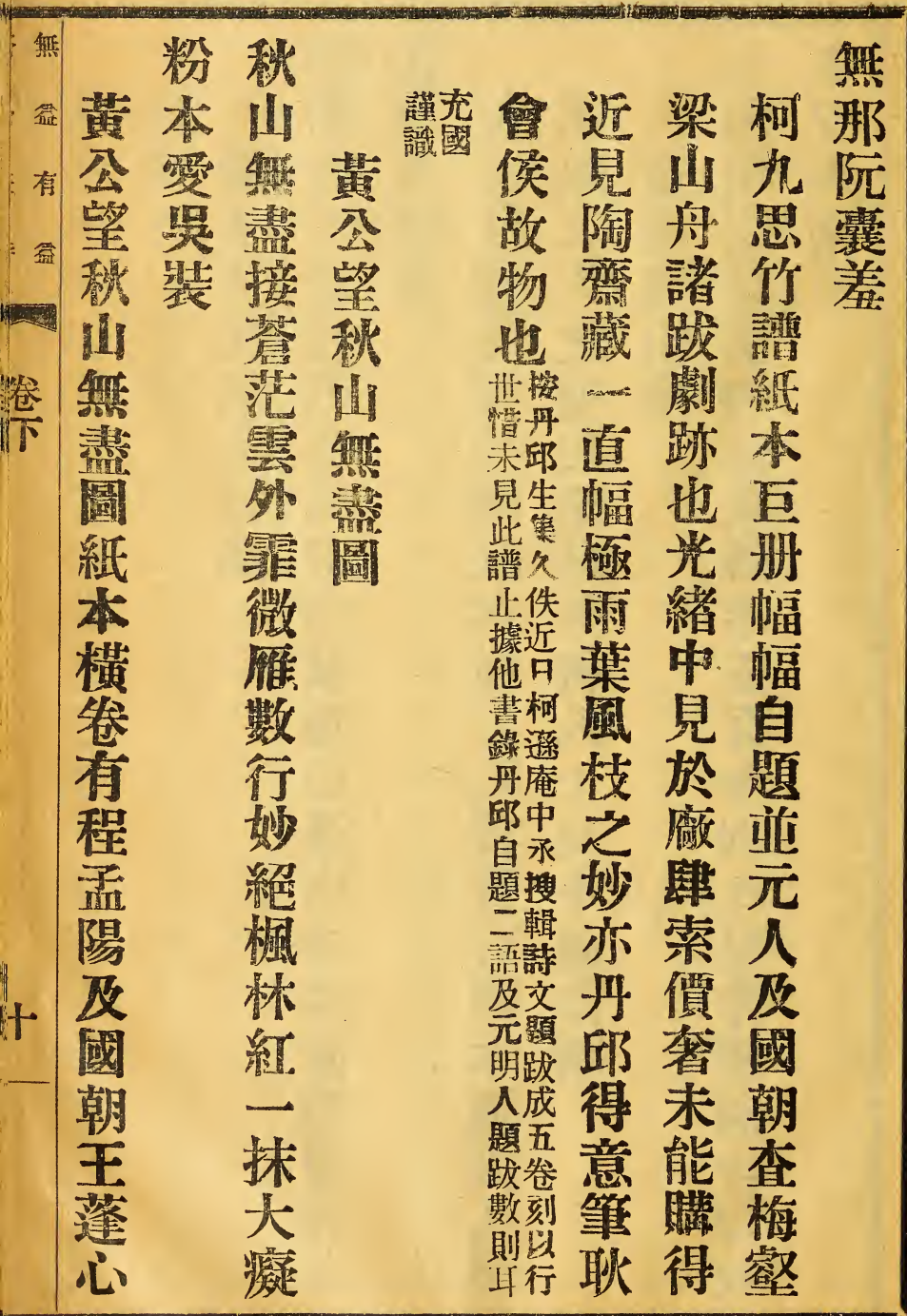




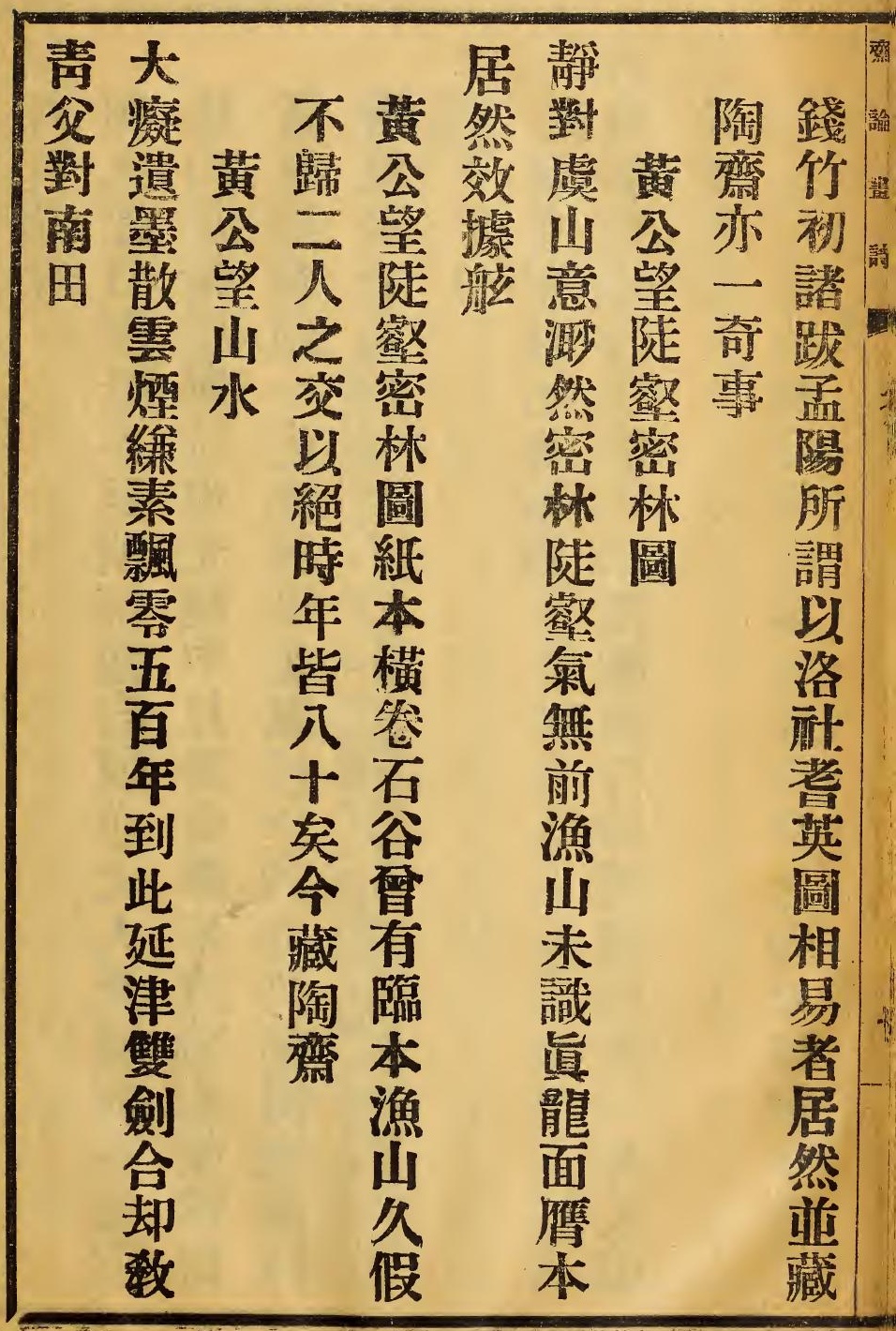




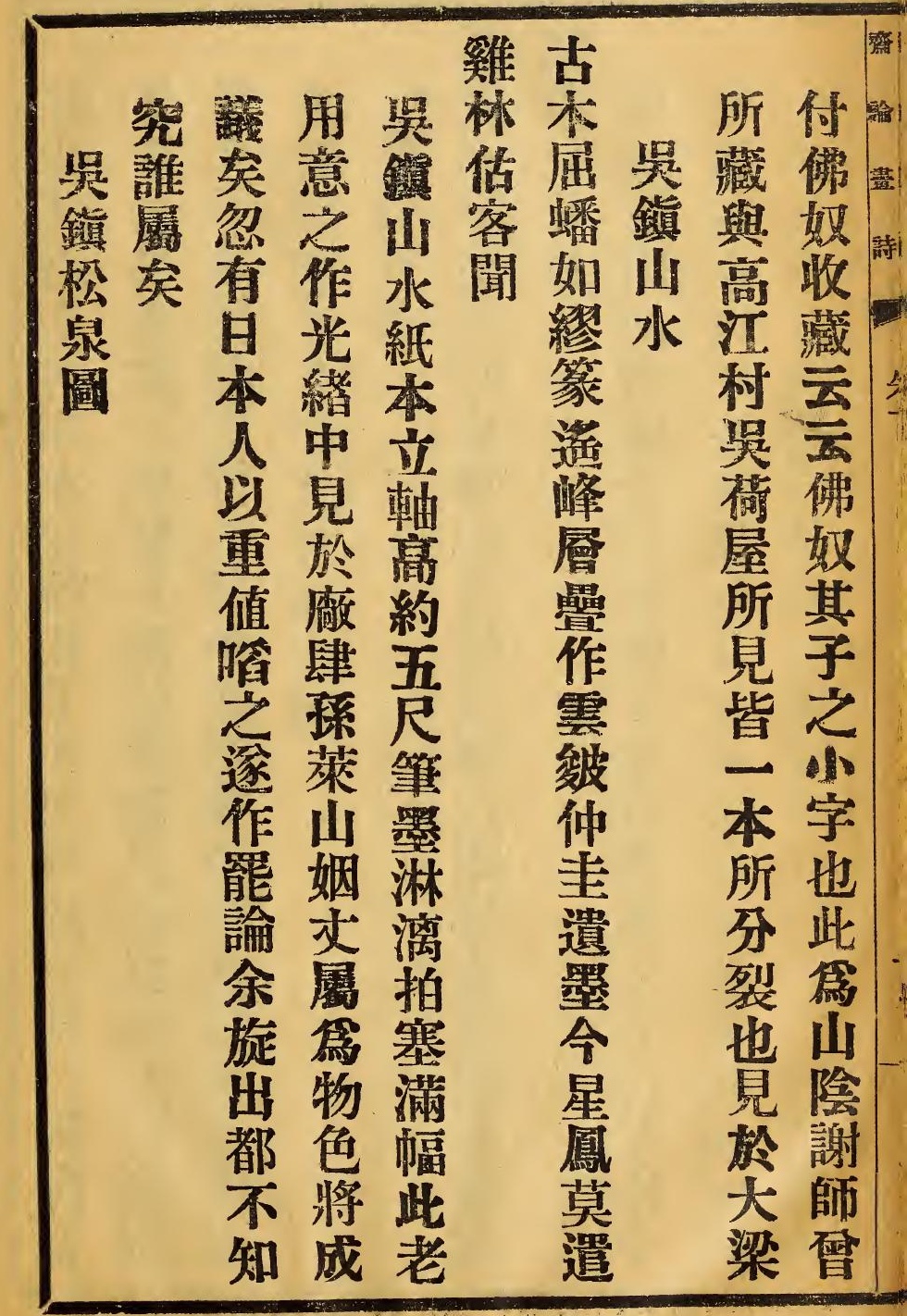




\begin{tabular}{|c|c|}
\hline 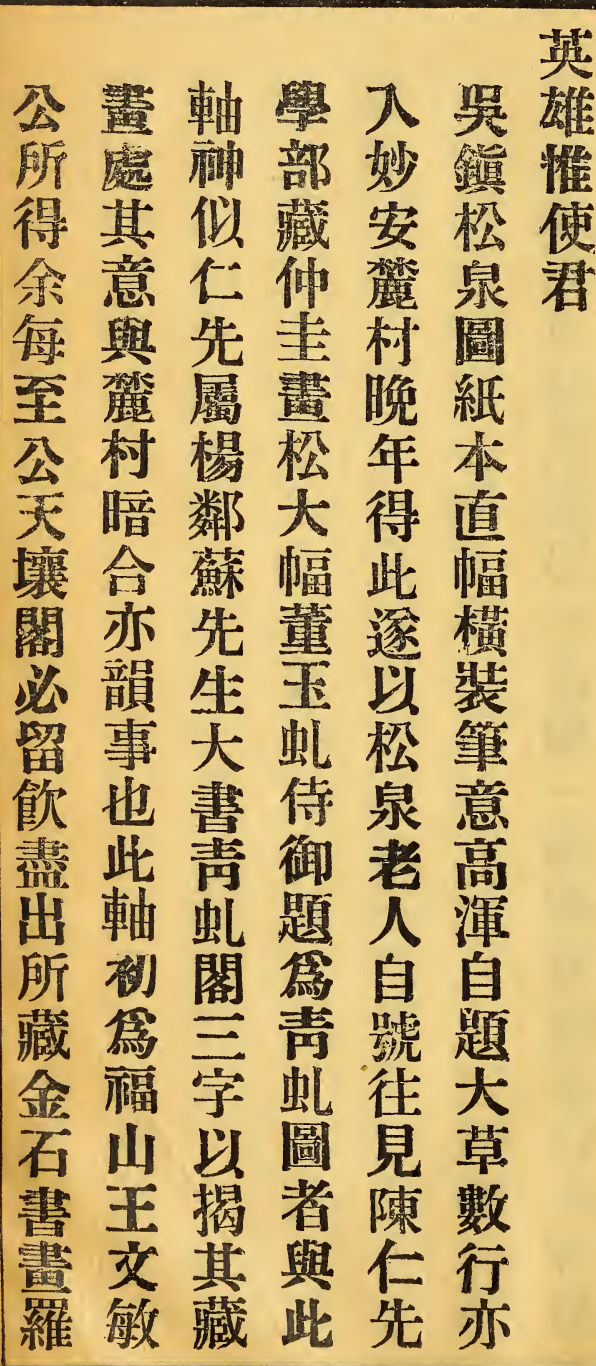 & 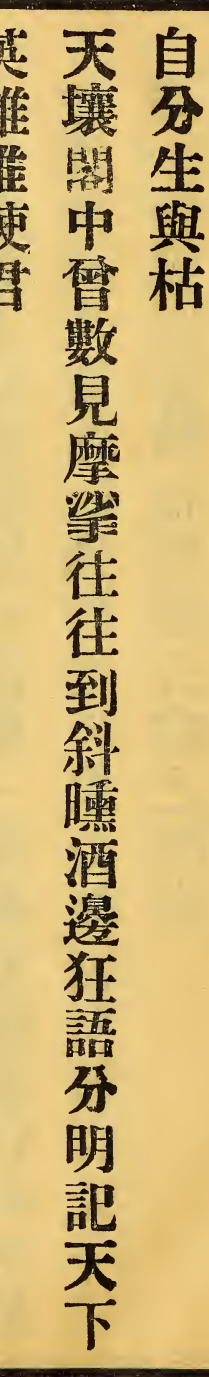 \\
\hline
\end{tabular}




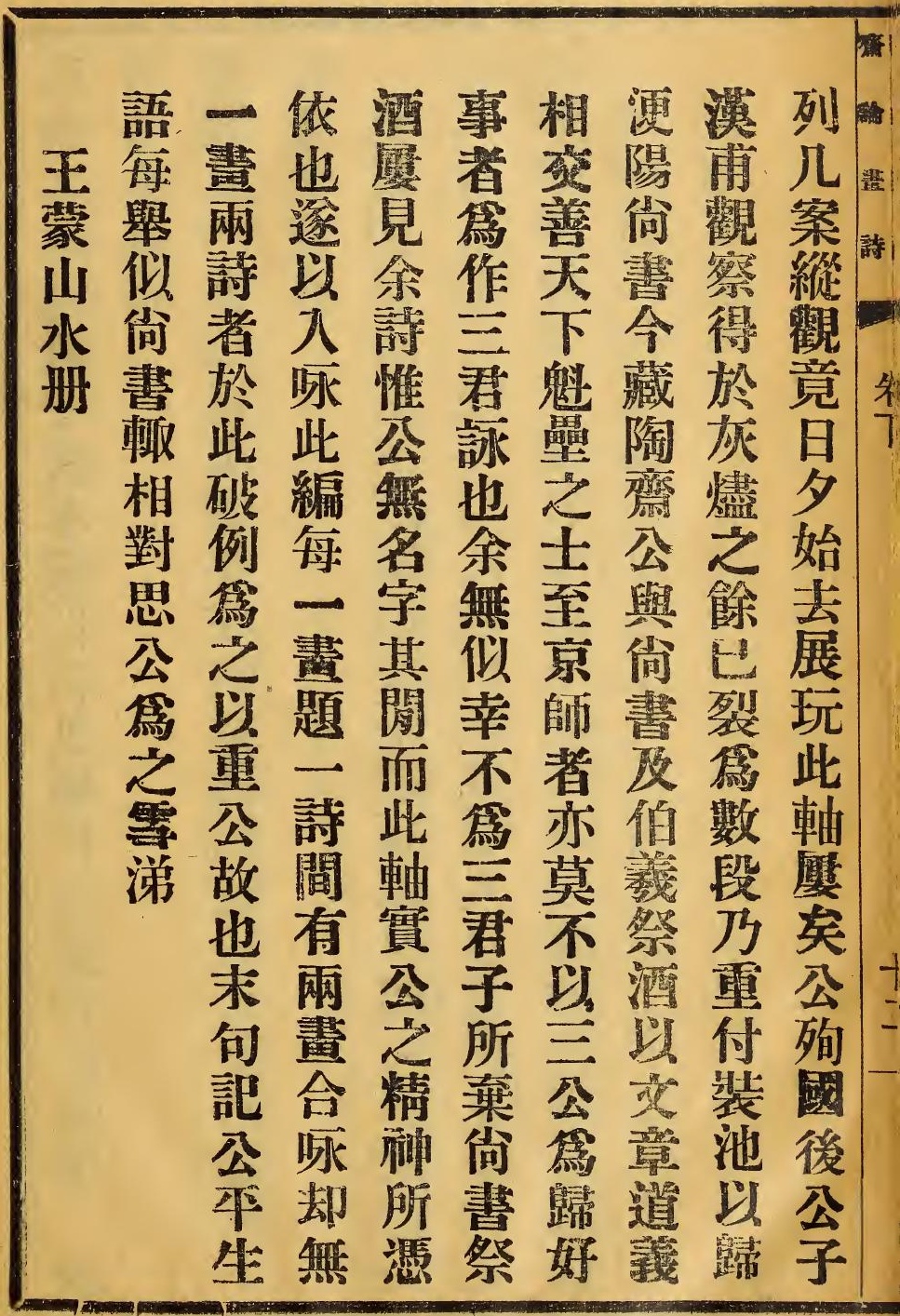




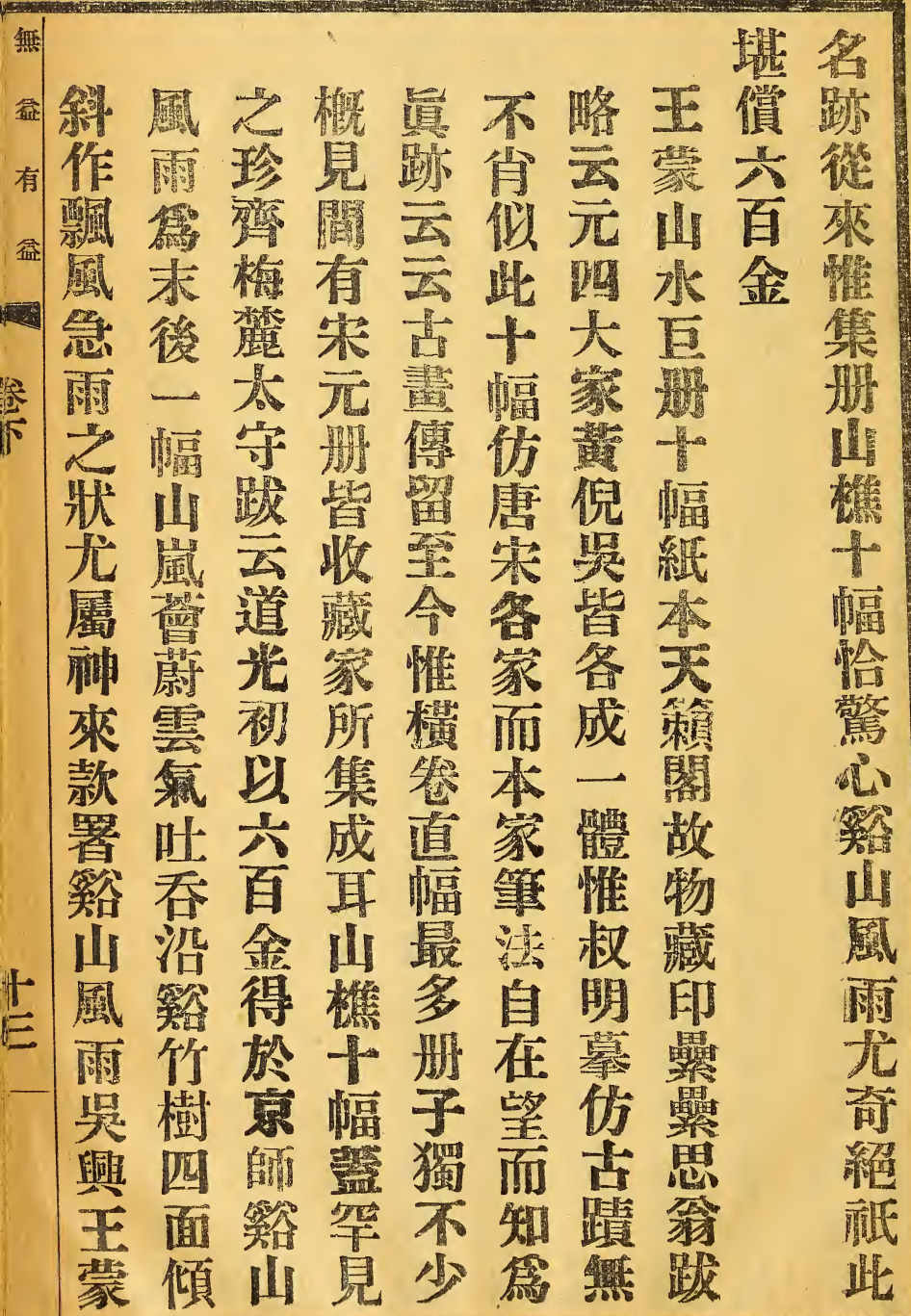




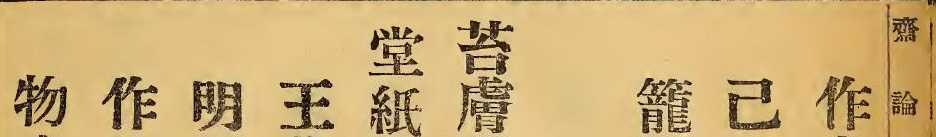

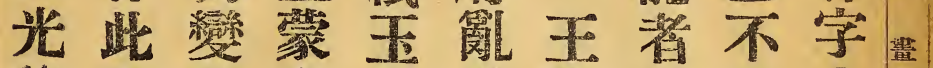

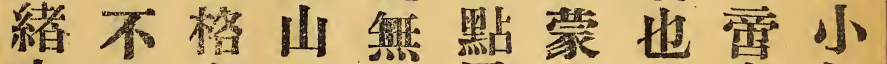

中知也水桭墨师突如

見能自直如水胃粟

於不題幅覀水机

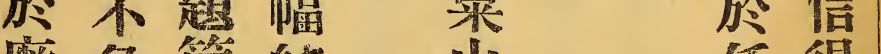

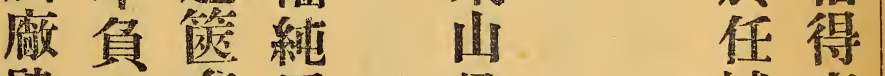

肆此有用䯚城意

松地

松任重披長李籍

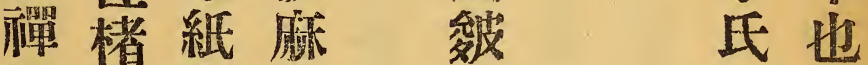

老枯摩融篗州祗

人其㧘點似人此

與得十觜麻所 -

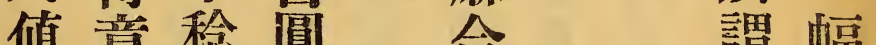

值意稳圆合

四可不勁著

百知忍乍嶃

金鴊着見樵

想覀筆似雅

入雲令器意

均年晨伂作

㭚艾興圭

畫故 到叔

澄

心

俱 幅

天 5

津 唇

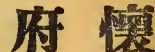

菒

李瓘

有之

七例

䀧估

鳥芝 
高

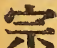

更

無

है

自

最:

TIT

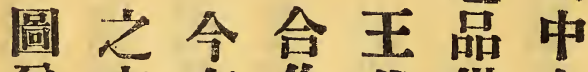

題 此

有

怒

曾亦在作蒙

柽

金

调

Fit.

파

但

矮

簝

先

生

激

営

久 邀 踖

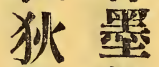

愧君緣

色楚量移

地 唧 観 唇

今啙著圖

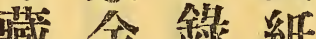

趾余錄紙

陶 此满 本

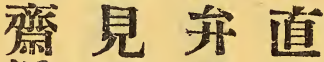

近脜隐幅

灭西㢄生

見印圖秀

公本思冷

新故筑售

得来題風

借 合王矣

香着蒙紙

光仙稚滑

人川 似

任移春

洞居冰

口圖色

䖴輀

花蒸

日 栗

月 信

長可

毒㻌

弁也

II A 篤韻

椎咏芺獨

雲然下跁

林 第 办

隉

居

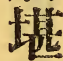

伯

仲

小此一叔

不

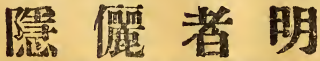

須 


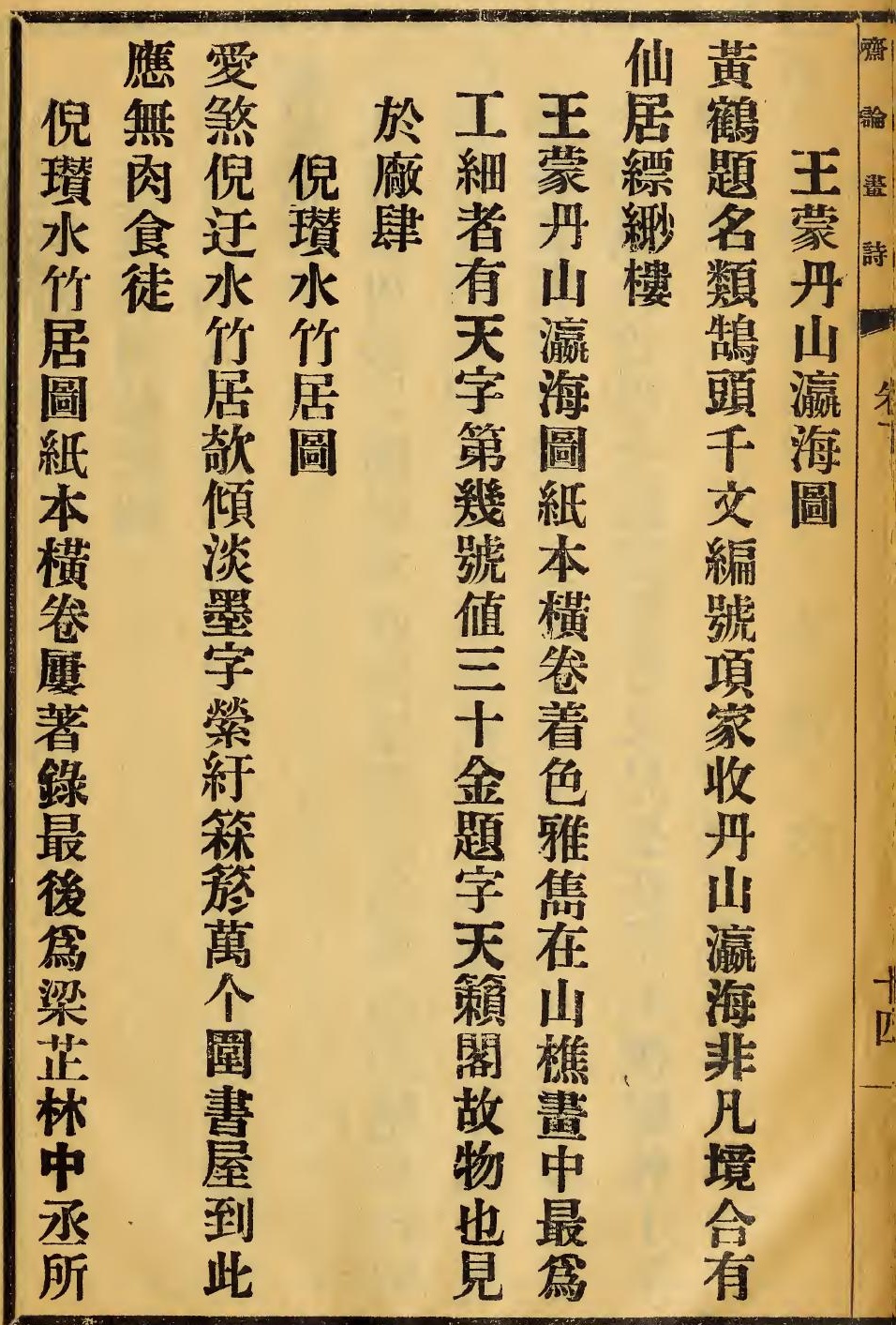




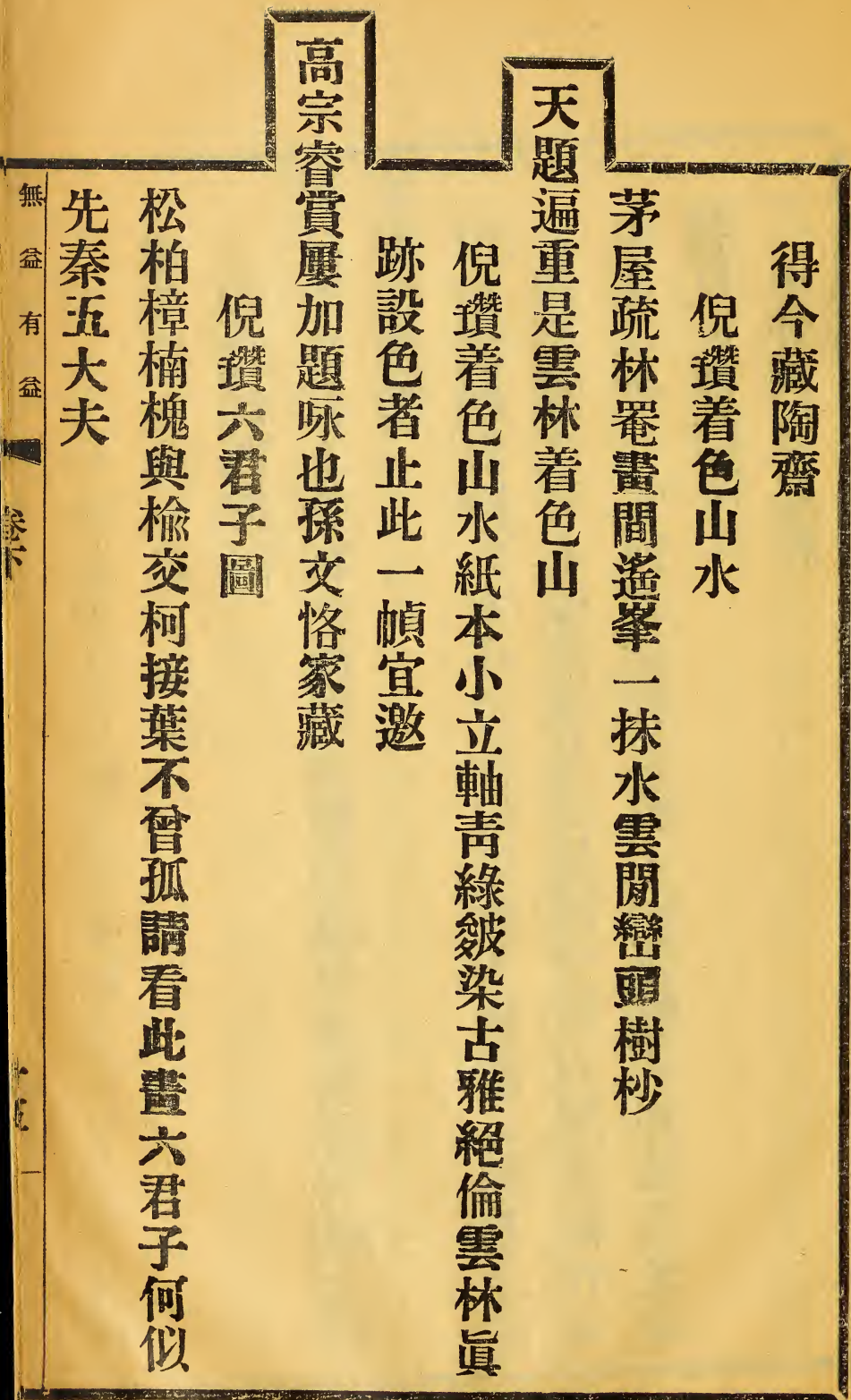




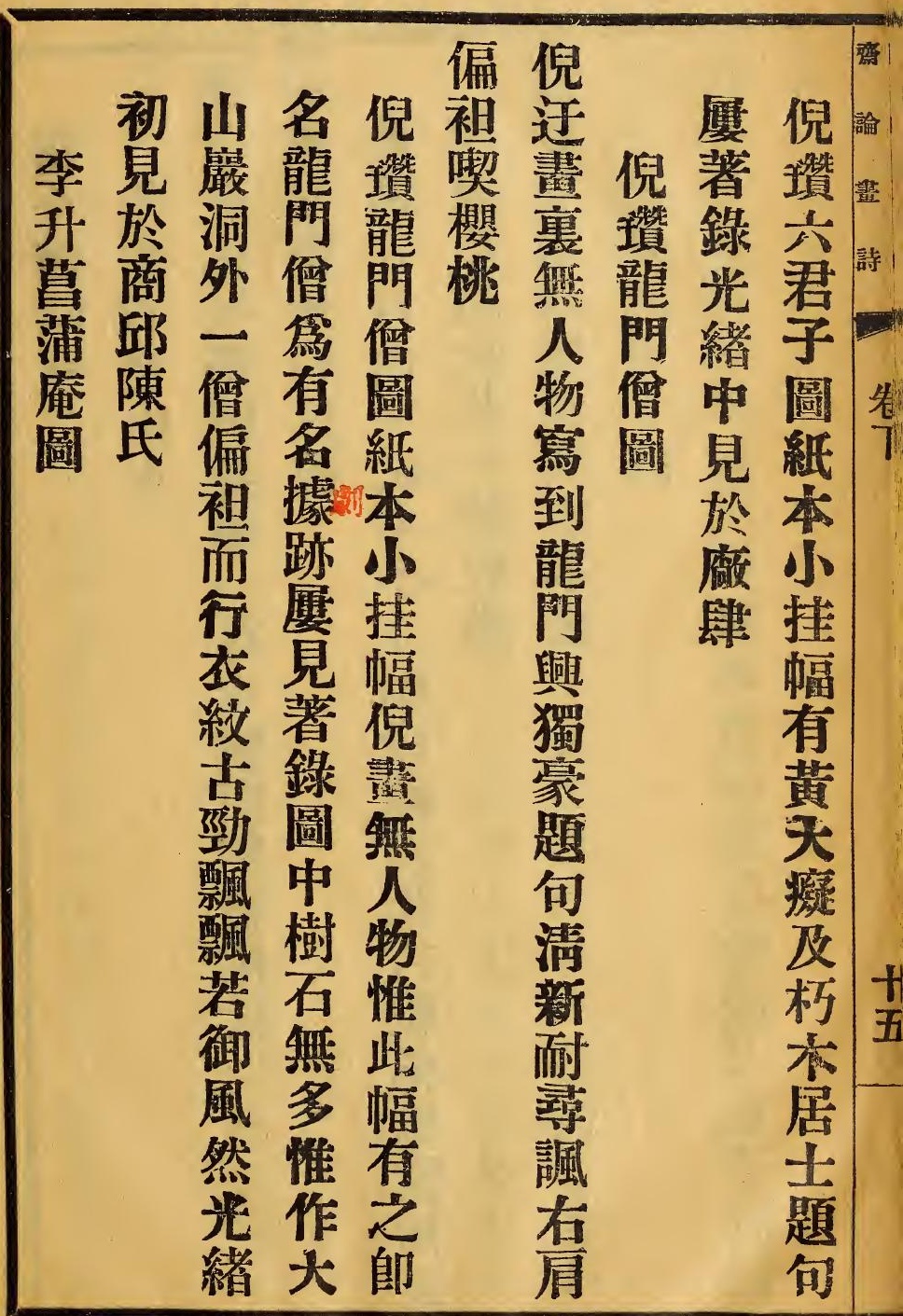




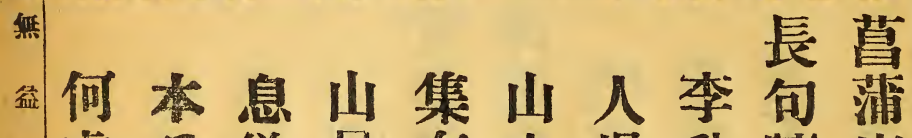

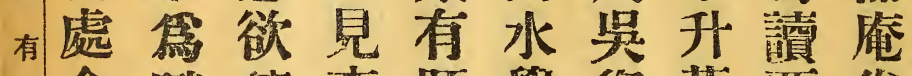
余賦使李題學復蒀覃焱 兄長前子年郭題蒲籍紫

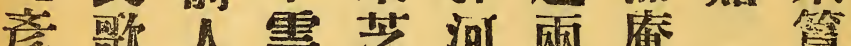
歌人雲芝河两庵 奇前二兽山陽段圖 先徵段蒲墓至鐵紙 生同風庵李正厓本 得人韻卷紫中弟橫 此載存於筫一子管 於啄予市䓪好也自 大之集上蒲手升至 梁云中将庵也㴚 正 人云殊鸽圖㧒梁以 家令可有長覃人逮 卷芝感力歌彩字洪 中山也者一先子武 多摹乃得首生雲題 梁本屬之序復赤者 蕉不芝持畧初作凡 林知山來云㭚紫甘 少在摹歎芝詩筫三

娈

初

\#

吗

題

何

H

芝

山

蓦

本

合 块 將 


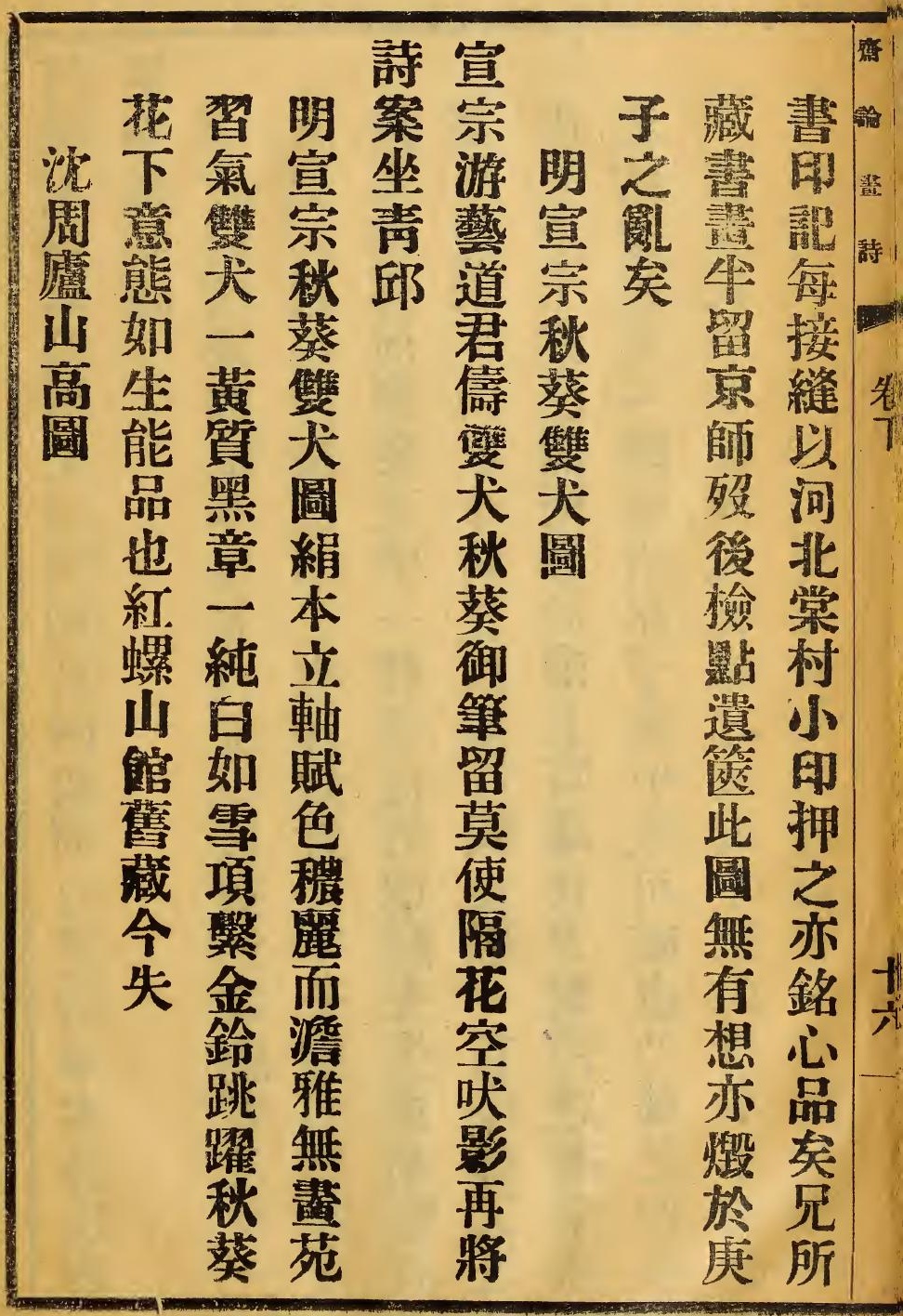




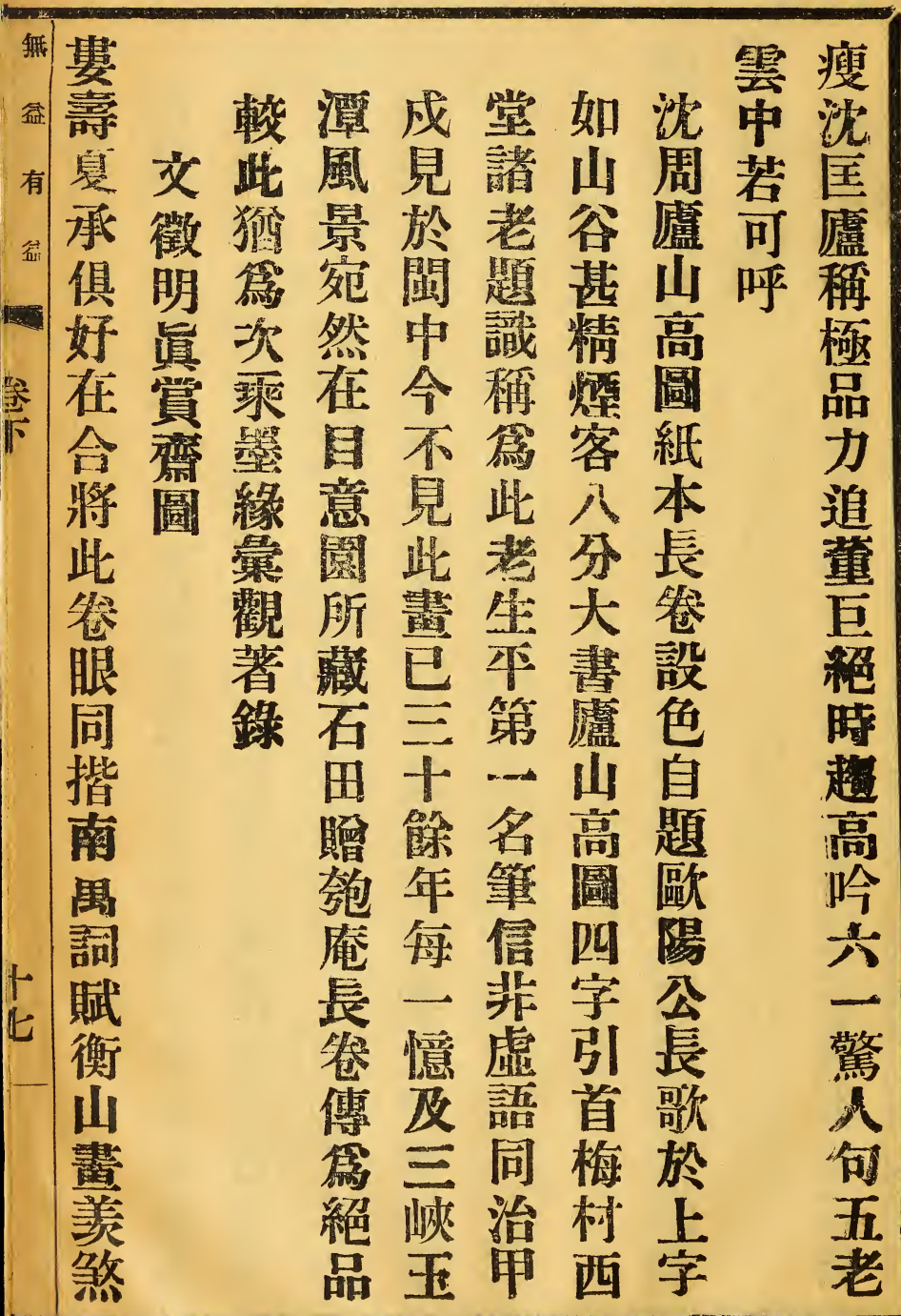




\section{呼 浪}

唐 鐙 跡

寡畫林

虎虎

邱邱

ili

圆

絹

綃

本

權

㮌

烺

筆

黑

䖢

全

仿

李

睎

古

而

$士$

氣

尤

雼
氏則藏劄交家

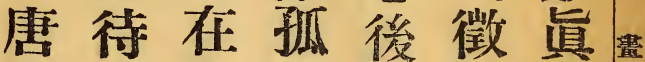
寅詔臨本哑明賞 虎此川見爪眞嶎 邱圖李於翅顠

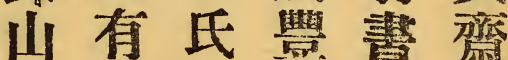
圆二有賦寡圖 垤石者营紙 綵印婁䂟本 壆本壽賦兴 絸行碑亦聟 著世今精交 錄此藏嶨秀 乃参松壽 步 別光㦷夏雅 本緖老承蘦 也初人嫕衡

見均磈山 於䂟㫮極 歒夏唯用 邱承中意 㷊碑所作 


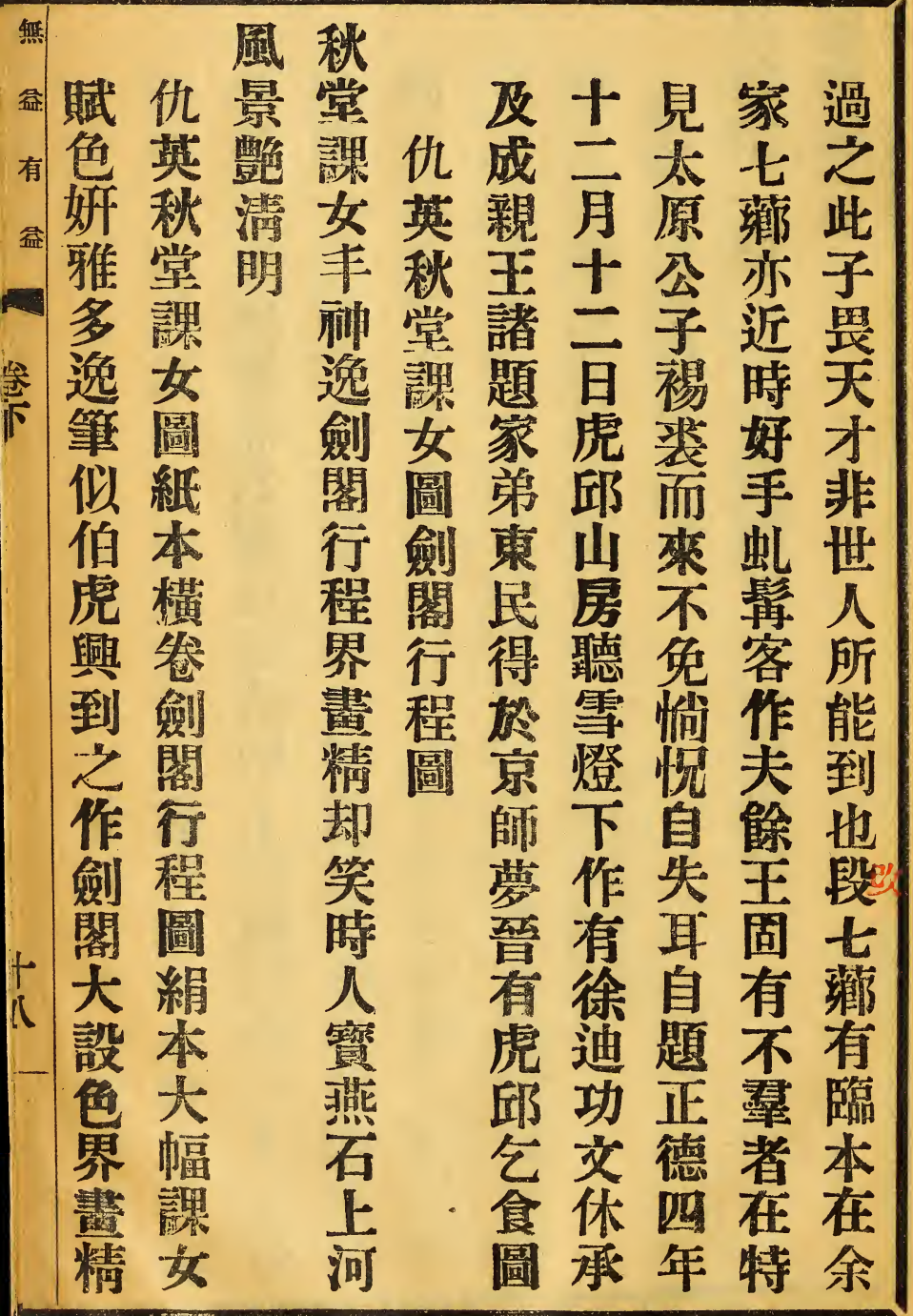


天

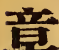

题 昆

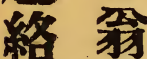

南父圖家彺漚嚴

䞍等 末

其 所

可見

驚昌藏

哂㫐

婉 也

出本

话 棓

筆

婉 草

變

圆

中

水

石

妍

赢

得

見

堂

圖

於

紊

師

成按

寉十

傳洲

世寫

無清

多明

也上

忘河

國圖

謹三

識年

留

置往

一以

管

可

虎

邱

波

亦 摹

礁 腐

畏篓

女有

也

贋

圖 直

䑶

鏓

署

塘 霞

許 張

苂瀷

恪端

余

看磺

㭗 玩

鸣 而

十清

此

鼎

後

此

實

会橥所

年 明

生 莁

出

每貿

笑本

收領

藏 不

上管

河

.

好

見

事

仇

谪

目

惟

明

未

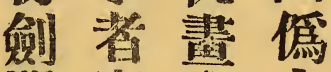

始

嘗代

見繁

宣

多本

矣尤

實與

則過惟多众䃘

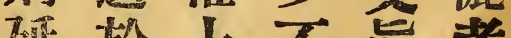

趠於上不基者

樹實河霄跡垖 


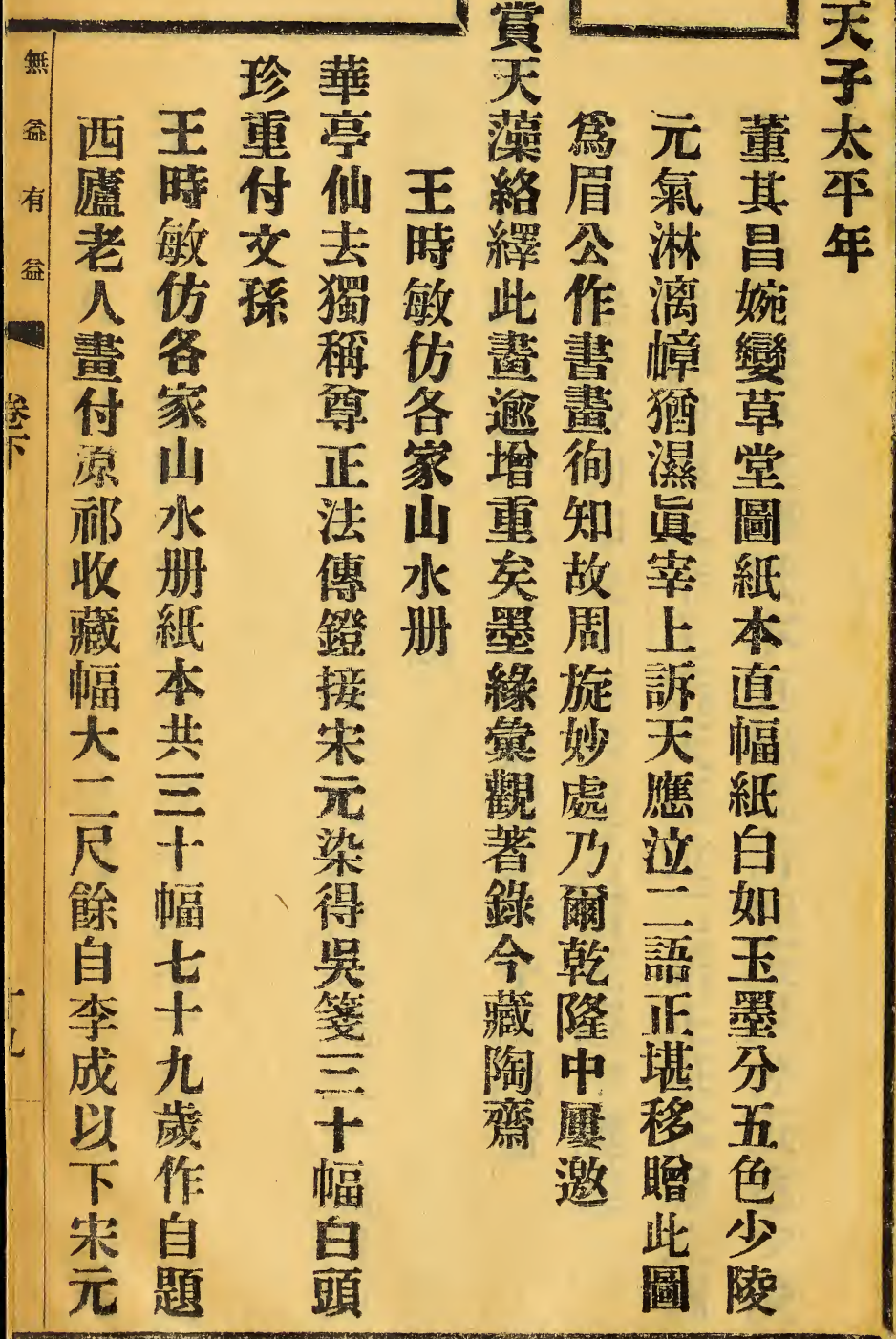




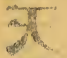

tats

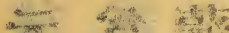

is

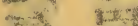

rot

- We

1)

Fiv of

T.t.

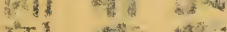

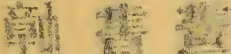

$x^{3}+2 \times 2+2$

dist

क्षेत्र

â:

4. . 5.

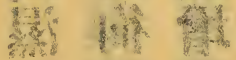

(1).8.

If

(r)

s.m

$\frac{7}{32} x^{2}$

is $x^{2}$

1

क्ष.

क.

sin

to

tain

ts

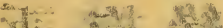

को

का

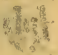

है। की

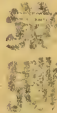

का

+alus

(x)

+. Pres

सौन

in

an

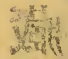

- 35

\&.

is $x^{2}$

$-3$

re?

तो

से

inis ât.

of the

\&

then

2.

iㅣ랄

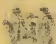

का

3t:

sth

as

की

os an

PI

$y^{2} x^{3}$ ?

का की

$02 x-5$

$\sqrt{3-3}$

4 .

तो

(1)

$x^{+}=$

$3 x^{3}$

*at

5.

int

ist.

then

A n .....

4

(5) Bd?

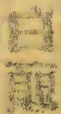

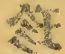

sf

$-5$

and $x$

तै

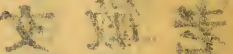

से है।

तit

करत ted

- $x^{-4}+3$

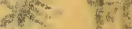

3) 53

अंक सीतें

क का

If

If $2 x+$.

a.

Af int

की.

cosion 4

Atumest

desements

- $\frac{1}{8}$

का औो 2 की

th

and

- $\frac{2}{1}-x^{2}-2$

की

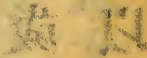

$-\frac{1}{4}$ का कू

D* $* \mathbb{R}^{*}$

a $=2$ of

होग 
驚 思

渚題年王倒桑不

间識 用鑑

的

見數 意犬

然 數 合䯕

天謂作淋

梁珍覑圖

重 綿 紙

愛津 本

護六楅

不十營

減 歲 水

来 時 墨

元 閉 褔

名人稍

跡上用

云此赫

可 䉆 黛

謂 諝 蒼

具大秀

眼喜入

矣過古

光望中
株墨王十第蒙

商 法 鑑得一摹

政 付

廉龍西從殆

州湫巨品渥

州梑已 哭遍

栭圆足抱信

肖

䧼

將

跡

鼼

求

的

明

得

龍

泚

秝

圖

$\rightarrow$

管

白

頭
冠仙劇

時觀跡

賢察也

矣假德

觀 砩

票

属 太

陸等

子 鐵

大 齍

命 中

臨 本

摹 朝

一名
藍琴 


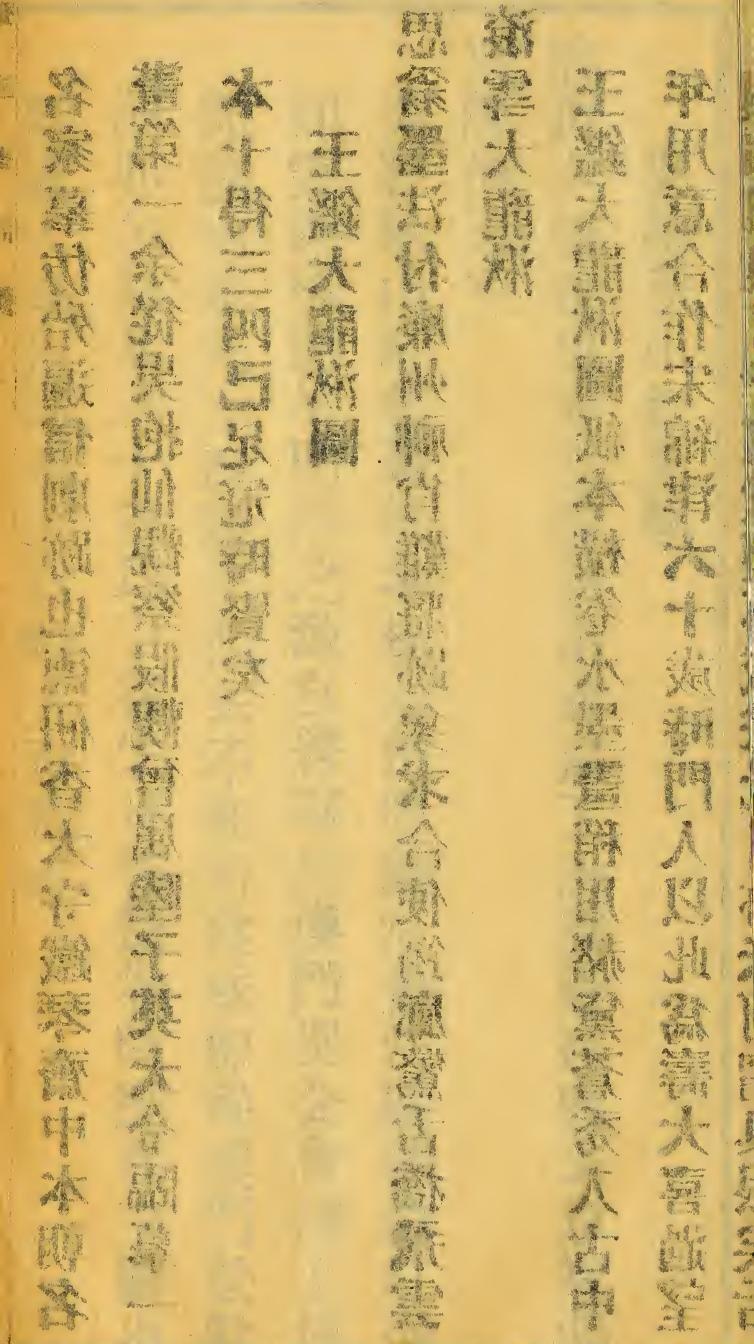




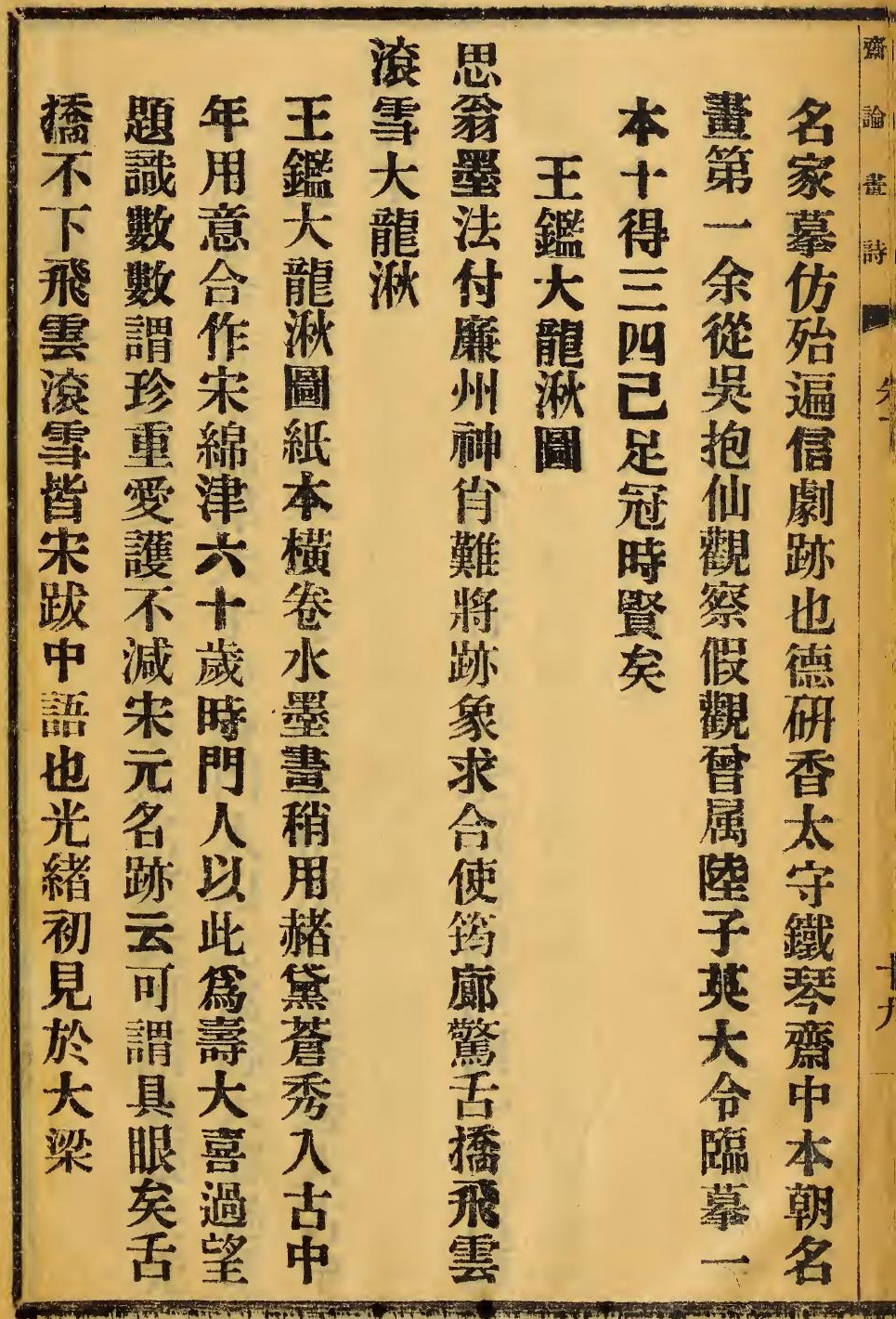




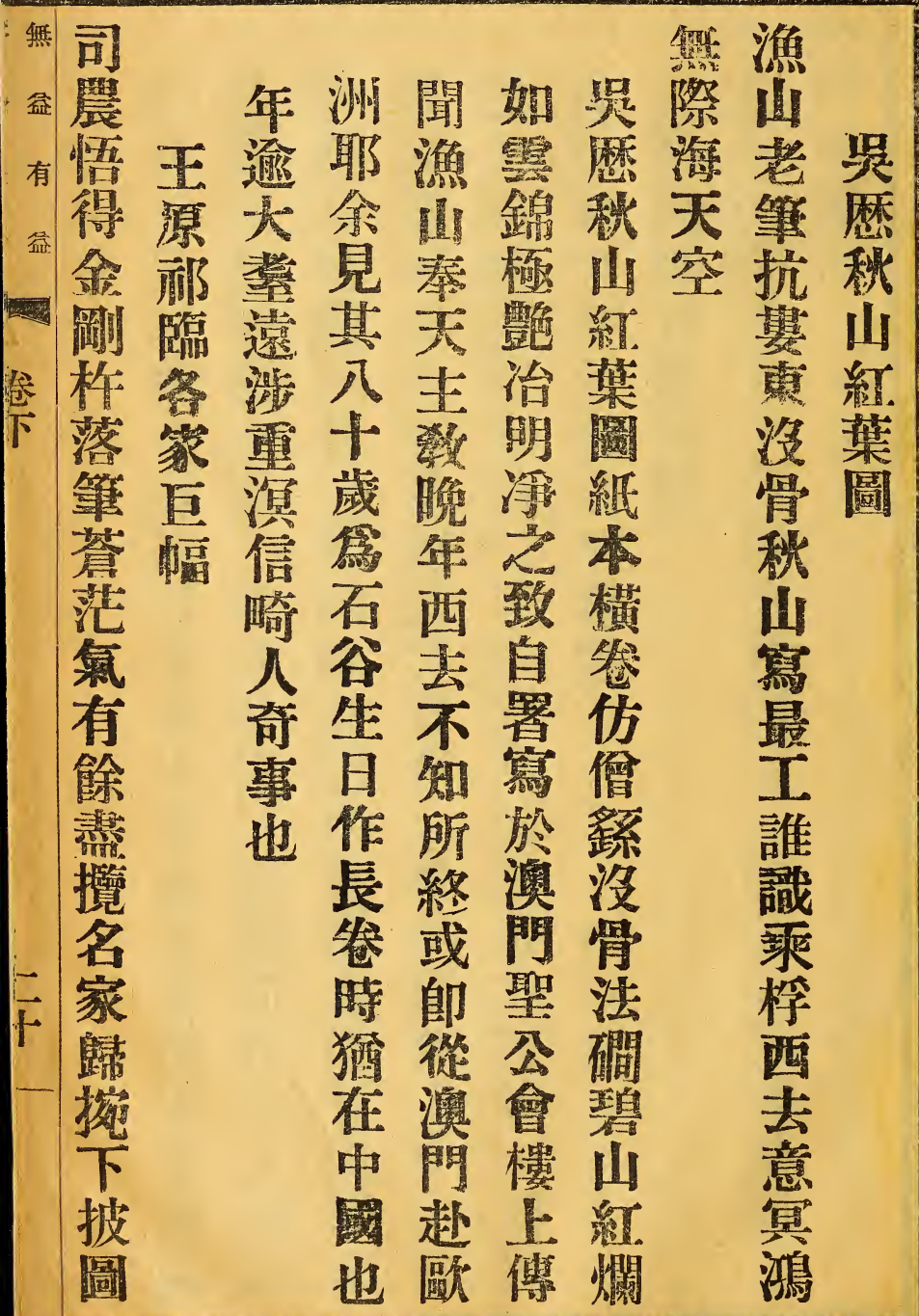




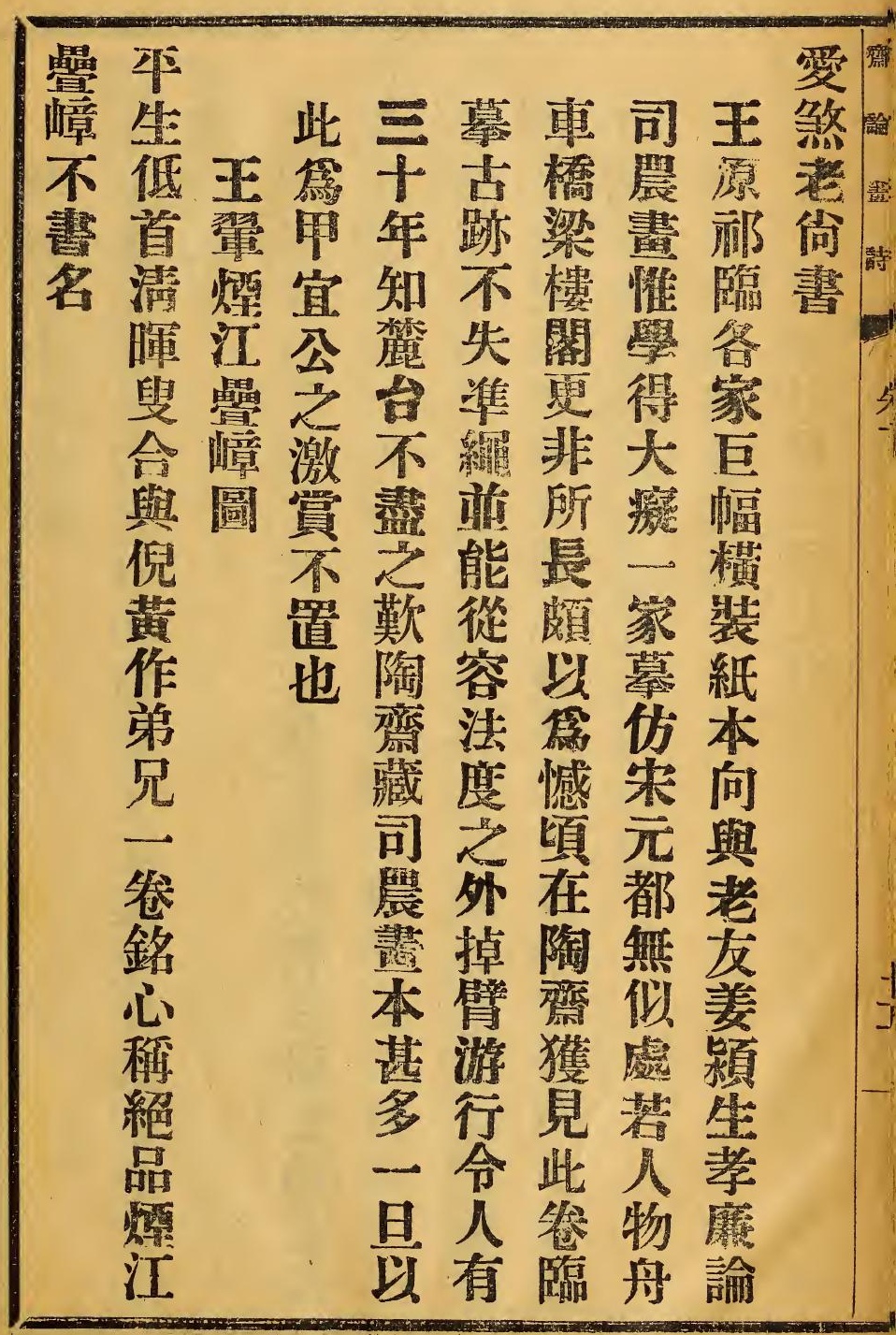




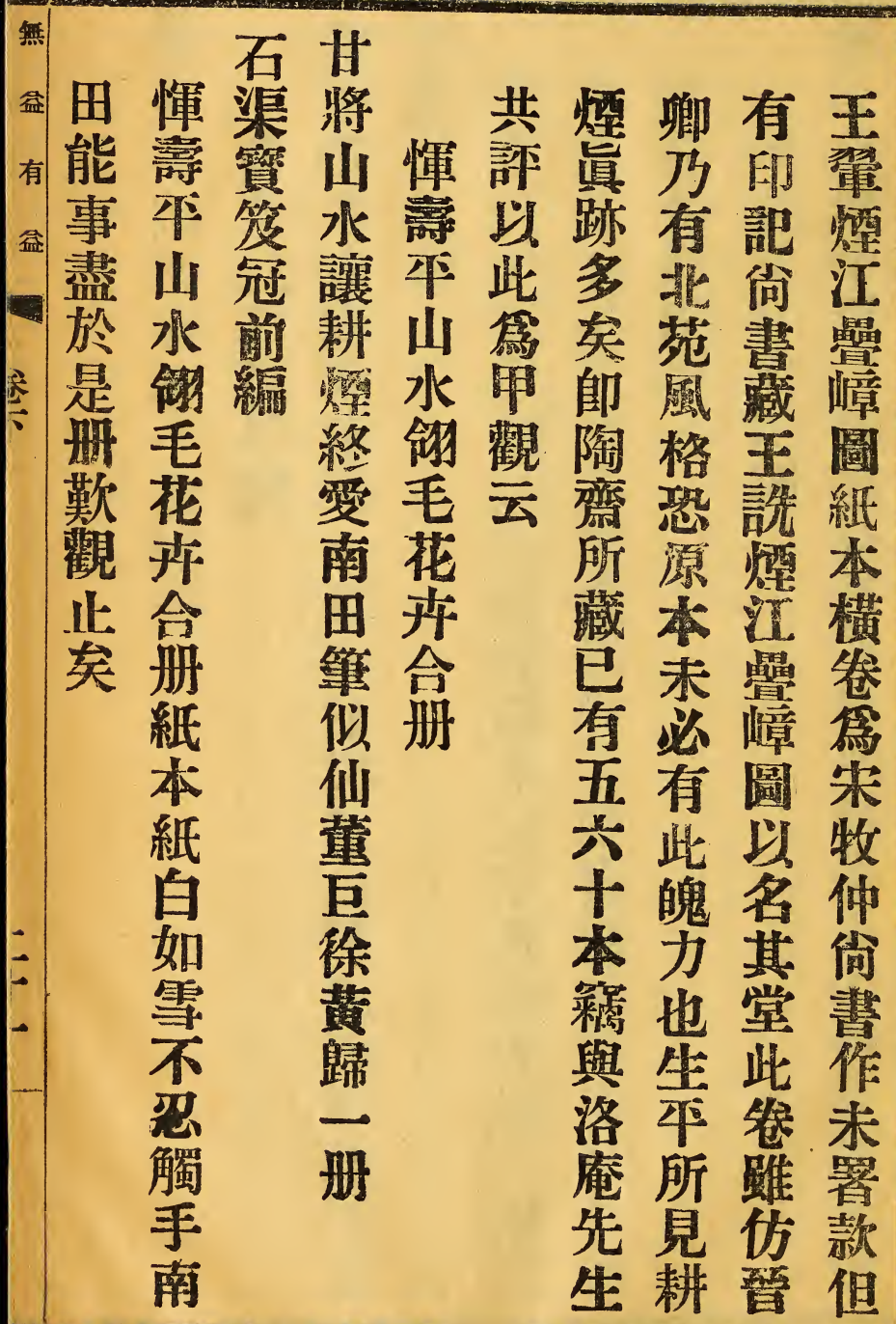




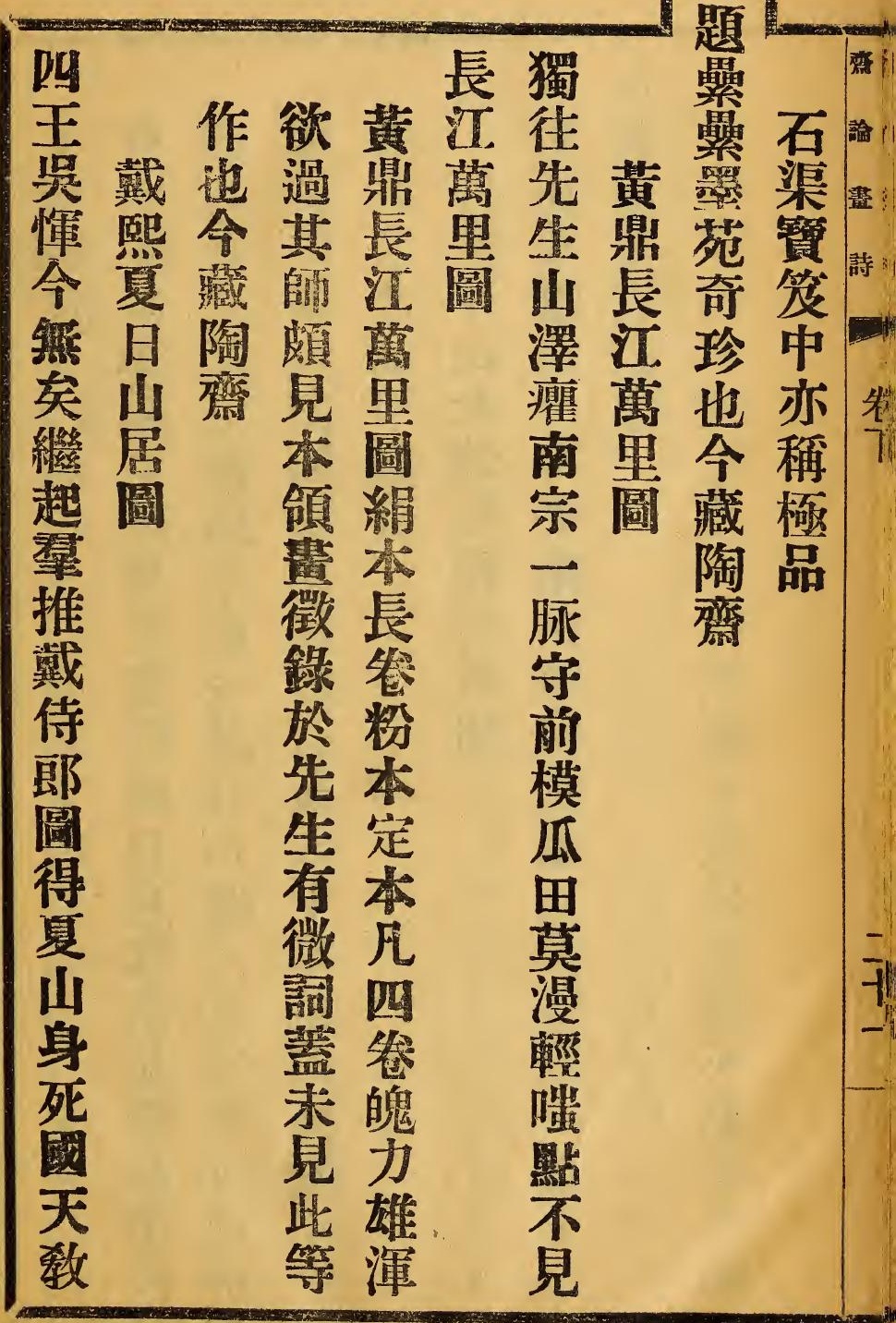




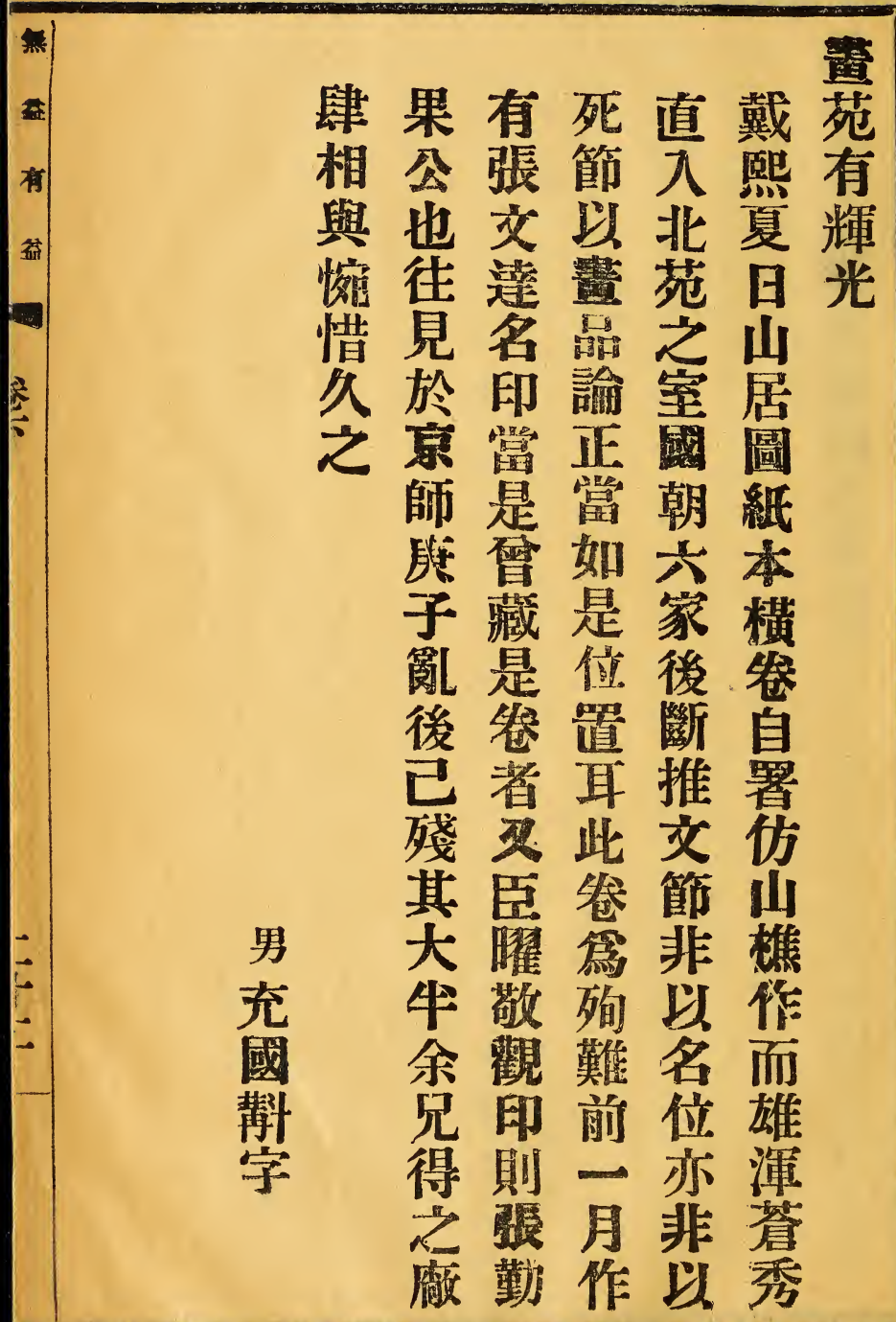




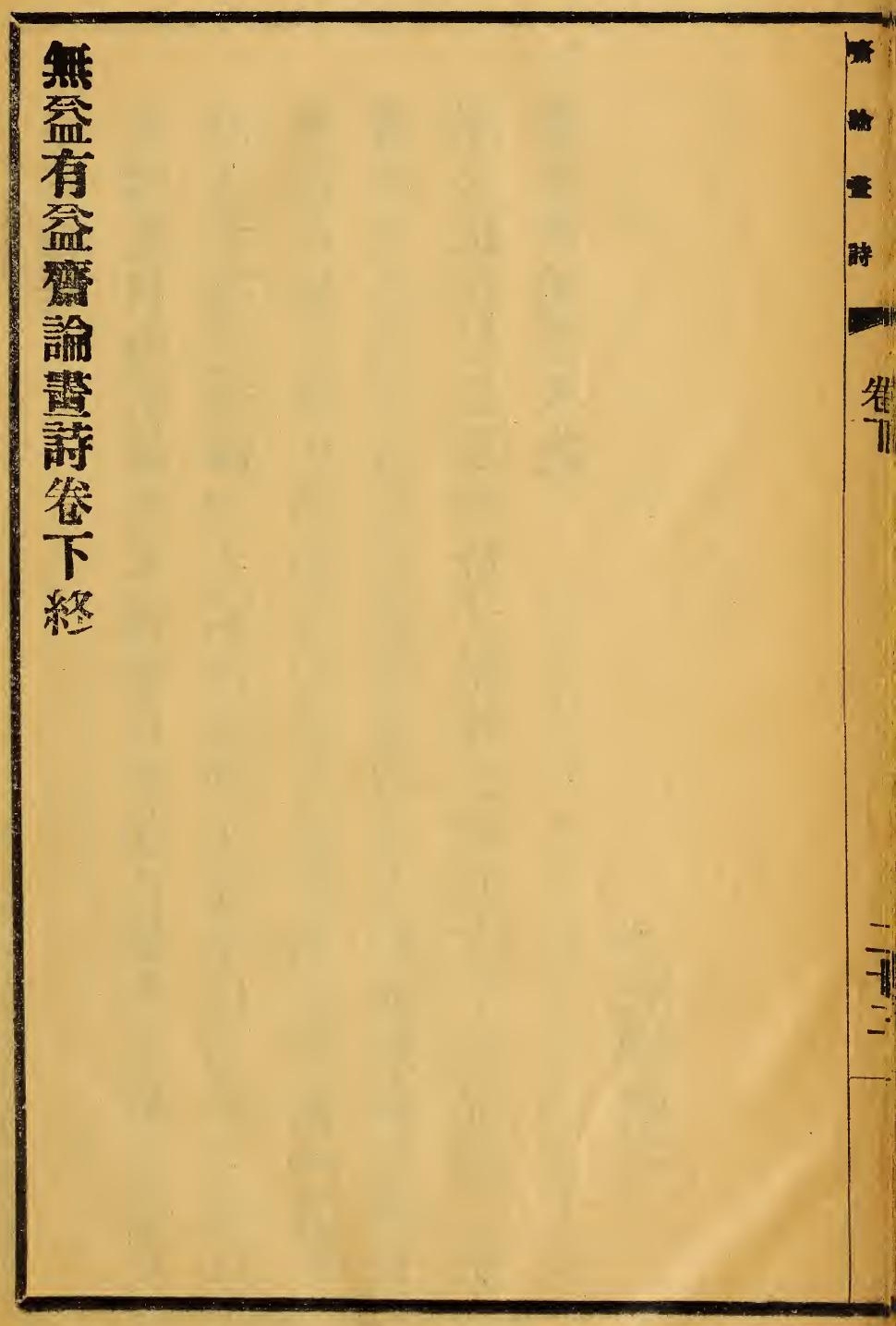




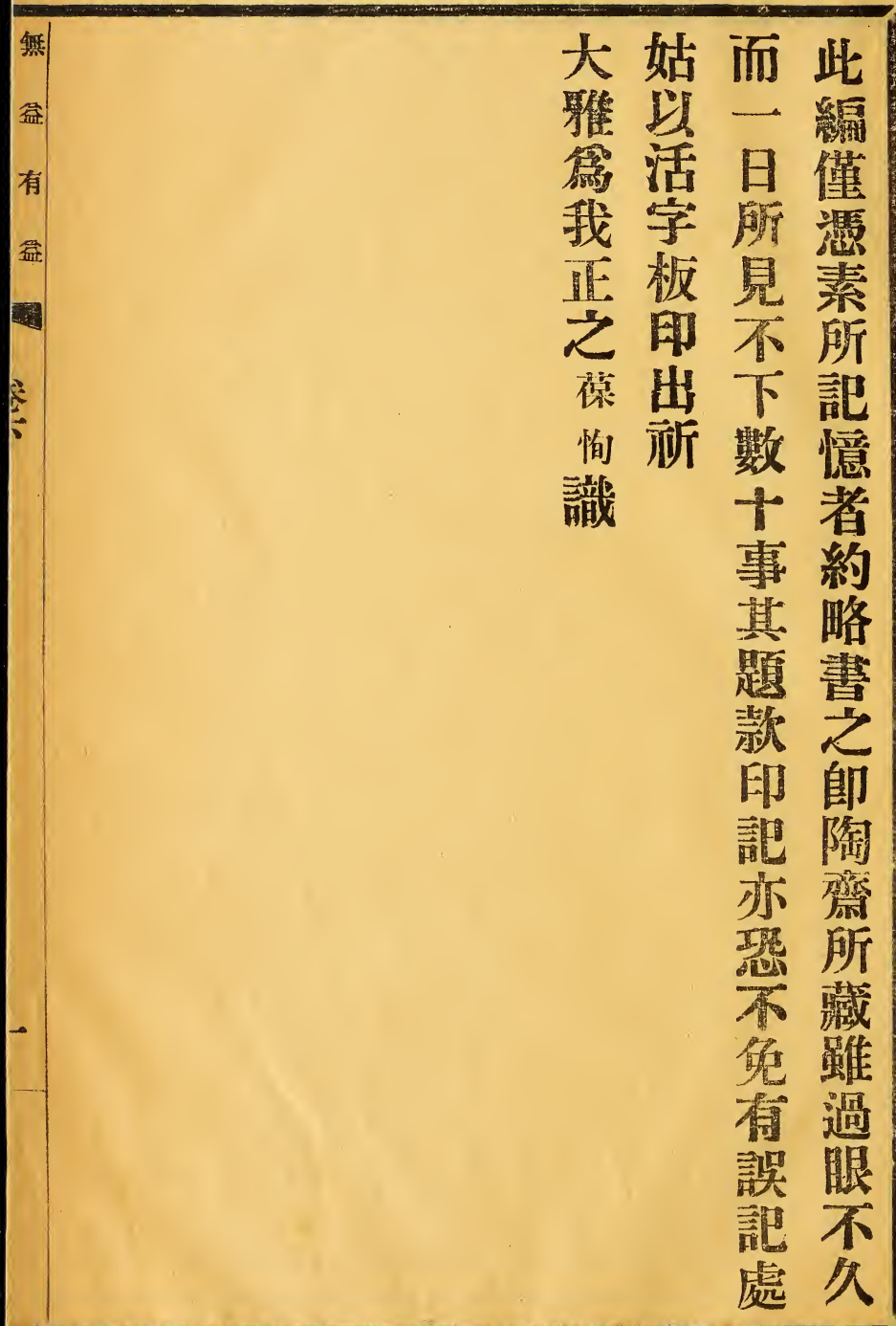




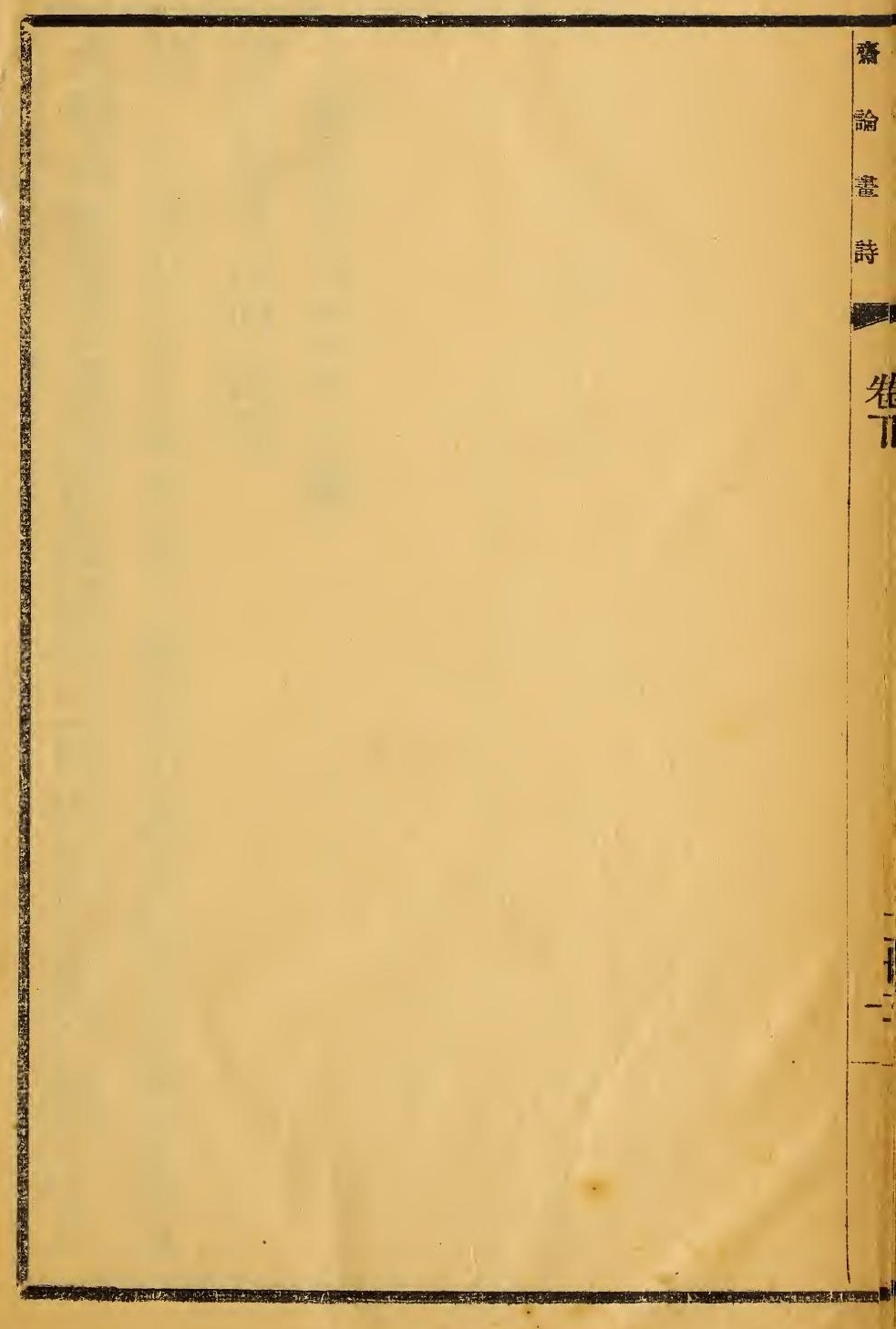



SMITHSONIAN INSTITUTION LIBRARIES

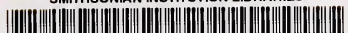

39088017295338 